UNIVERSIDADE DE SÃO PAULO

FACULDADE DE ECONOMIA ADMINISTRAÇÃO E CONTABILIDADE DEPARTAMENTO DE CONTABILIDADE E ATUÁRIA

PROGRAMA DE PÓS-GRADUAÇÃo EM CONTROLADORIA E CONTABILIDADE

TOMADA DE DECISÃO, HEURÍSTICAS E VIESES NA ANÁLISE DAS DEMONSTRAÇÕES CONTÁBEIS

Roberto Bomgiovani Cazzari

Orientador:

Prof. Dr. Luiz Paulo Lopes Fávero

SÃo PAULO 
Prof. Dr. Marco Antônio Zago

Reitor da Universidade de São Paulo

Prof. Dr. Adalberto Américo Fischmann

Diretor da Faculdade de Economia, Administração e Contabilidade

Prof. Dr. Ariovaldo dos Santos

Chefe do Departamento de Contabilidade e Atuária

Prof. Dr. Luiz Paulo Lopes Fávero

Coordenador do Programa de Pós-Graduação em Controladoria e Contabilidade 


\title{
TOMADA DE DECISÃO, HEURÍSTICAS E VIESES NA ANÁLISE DAS DEMONSTRAÇÕES CONTÁBEIS
}

\author{
Tese apresentada ao Departamento de \\ Contabilidade e Atuária da Faculdade de \\ Economia, Administração e Contabilidade da \\ Universidade de São Paulo como parte dos \\ requisitos para a obtenção do título de Doutor \\ em Ciências.
}

Orientador: Prof. Dr. Luiz Paulo Lopes Fávero

\section{Versão Corrigida}

(Versão original disponível na Biblioteca da Faculdade de Economia, Administração e Contabilidade)

\section{SÃO PAULO}


Autorizo a reprodução e divulgação total ou parcial deste trabalho, por qualquer meio convencional ou eletrônico, para fins de estudo e pesquisa, desde que citada a fonte.

Catalogação na publicação

Serviço de Biblioteca e Documentação

Faculdade de Economia, Administração e Contabilidade da Universidade de São Paulo

Universidade de São Paulo

FICHA CATALOGRÁFICA

Elaborada pela Seção de Processamento Técnico do SBD/FEA/USP

Cazzari, Roberto Bomgiovani

Tomada de decisão, heurísticas e vieses na análise das demonstra-

ções contábeis /Roberto BomgiovaniCazzari. -- São Paulo, 2016.

$186 \mathrm{p}$

Tese (Doutorado) - Universidade de São Paulo, 2017.

Orientador:Luiz Paulo Lopes Fávero.

1. Tomada de decisão 2. Finanças comportamentais 3. Heurísticas

4. Vieses5. Demonstrações contábeis I. Universidade de São Paulo.

Faculdade de Economia, Administração e Contabilidade.II. Título.

CDD -658.403 
A todos os leitores 



\section{AGRADECIMENTOS}

Gostaria de agradecer a todos que me ajudaram (direta ou indiretamente) para que essa tese viesse a se tornar realidade.

Em especial, ressaltar o incomensurável apoio familiar que obtive, na figura de minha mãe,minha avó e meu primo que estiveram comigo nos bons e nos maus momentos.

Finalmente, não poderia deixar de fazer uma menção especial ao professor e amigo Doutor Luiz Paulo Lopes Fávero, meu orientador, que sempre me auxiliou e auxilia com sua sabedoria, ética, honestidade e competência. A ele, todo o meu apreço.

Também não posso me esquecer de mencionar grandes amigos que fiz em minha estadia na FEA/USP durante essa década (duas graduações, mestrado e doutorado). Em particular, gostaria de homenagear figuras icônicas, como Renato Zhan, Paulo Rogério Trindade Carlos, Renato Oso, Rodrigo Luz e Silva, Janilson Suzart, Paulo Júnior Homero, Samir Sayed, Fabrizio Zorzella, Wesley Santana, Sofia Lacerda, Ludmila Melo, Bianca Checon e Eduardo Flores.

Adicionalmente, gostaria de homenagear alguns outros professores, que notadamente, marcaram minha carreira acadêmica na USP:

- Alexandre di Miceli;

- Ana Carolina Maia;

- Ariovaldo dos Santos;

- Bruno Salotti;

- Eliseu Martins;

- Fernando Murcia;

- Gilberto de Andrade Martins;

- Joanília Neide de Sales Cia;

- João Vinícius de França Carvalho;

- José Carlos Simón;

- Lucas Ayres; 
- Luís Eduardo Afonso;

- Maria Izabel Ramalho Martins;

- Nahor Plácido Lisboa;

- Nelson Carvalho;

- Ricardo Pacheco;

- Tatiana Albanez.

Concluo agradecendo a CAPES pela bolsa fornecida durante esse período no doutorado. 
Cem vezes, todos os dias, lembro a mim mesmo que minha vida interior e exterior, depende dos trabalhos de outros homens, vivos ou mortos, e que devo esforçar-me a fim de devolver na mesma medida que recebi 



\section{RESUMO}

Cazzari, R. B. (2016). Tomada de Decisão, Heurísticas e Vieses na Análise das Demonstrações Contábeis. Tese de Doutorado, Departamento de Contabilidade e Atuária, Faculdade de Economia, Administração e Contabilidade, Universidade de São Paulo, São Paulo.

Essa tese foi desenvolvida com vistas a responder ao seguinte problema de pesquisa:as heurísticas e os vieses influenciam o processo decisório dos indivíduos quando confrontados com demonstrações financeiras e contábeis publicadas pelas empresas? Baseando-se na Prospect Theory de Kahneman e Tversky, buscou-se verificar como as heurísticas da ancoragem, representatividade e disponibilidade geravam vieses e influenciavam o modo como os usuários tomam suas decisões utilizando informações de cunho contábil e financeiro. Para tanto, foram submetidos questionários contendo situações de decisão junto aos estudantes de graduação da Faculdade de Economia, Administração e Contabilidade da Universidade de São Paulo e aos analistas profissionais de uma grande instituição financeira brasileira. 369 estudantes e 55 analistas responderam o questionário proposto. Para evitar com que os resultados pudessem não ser confiáveis, nenhum dos respondentes sabiam que o questionário buscava identificar vieses no processo de tomada de decisão. Para os colaboradores, foi exposto que a pesquisa versava sobre o processo de tomada de decisão com base na divulgação de informações contábeis e financeiras, sem fazer qualquer menção ao estudo das finanças comportamentais ou vieses. Os resultados obtidos divergiram quando foram comparados os dois públicos estudados nessa tese: analistas de mercado de capitais e estudantes de uma das melhores faculdades de negócio do Brasil. Os resultados sugeriram que o uso da heurística da ancoragem não se mostrou significativa nem para os analistas e nem para os estudantes. Entretanto, o uso da heurística da disponibilidade se mostrou estatisticamente significativa, assim como a presença da noção de correlação ilusória e o efeito isolamento. Por sua vez, o efeito reflexão e a não observação da regressão à média foram percebidos somente na amostra composta pelos analistas profissionais da instituição financeira. Finalmente, o uso da heurística da representatividade só teve efeito estatístico na presença dos alunos.

Palavras-chave: Tomada de Decisão, Finanças Comportamentais, Heurísticas, Vieses, Demonstrações Contábeis. 


\section{ABSTRACT}

Cazzari, R. B. (2016). Decision Making, Heuristics and Biases in Financial Statement Analysis. Tese de Doutorado, Departamento de Contabilidade e Atuária, Faculdade de Economia, Administração e Contabilidade, Universidade de São Paulo, São Paulo.

This thesis has been developed in order to answer the following research problem: the heuristics and biases influence the decision-making process of individuals when faced with financial and accounting statements published by the companies? Based on the Prospect Theory of Kahneman and Tversky, this research sought to determine how the heuristics of anchoring and adjustment, representativeness and availability generated biases and influenced how users make decisions using accounting and financial nature information. To this end, questionnaires containing decision situations were submitted to undergraduate students of the School of Economics, Business and Accounting of the University of São Paulo and the professional analysts of a large Brazilian financial institution. 369 students and 55 analysts answered the proposed questionnaire. To avoid that the results could not be trusted, none of the respondents knew that the questionnaire sought to identify biases in the decision-making process. It was explained that the survey questionnaire was about the decision-making process based on the disclosure of accounting and financial information, without making any mention of the study of behavioral biases. The results diverged when both public studied were compared in this thesis: capital market analysts and students of one of the best business schools in Brazil. The results suggested that the use of the anchoring and adjustment heuristic was not significant neither for the analysts and neither for the students. However, the use of the availability heuristic was statistically significant, as the presence of the concept of illusory correlation and the isolation effect. In turn, the reflection effect and no observation of regression to the mean were perceived only in the sample of the professional analysts of the financial institution. Finally, the use of the representativeness heuristic only had statistical effect in the student's sample.

Keywords: Decision Making, Behavioral Finance, Heuristics, Biases, Financial Statements. 


\section{LISTA DE QUADROS}

Quadro 1 - Informações complementares colhidas junto aos alunos da FEA/USP................ 60

Quadro 2 - Informações complementares colhidas junto aos analistas da IF ......................... 60

Quadro 3 - Conjunto de Variáveis Explicativas - Regressão Logística - Hip. 1 (efeito certeza) - FEA/USP

Quadro 4 - Conjunto de Variáveis Explicativas - Regressão Logística - Hip. 2 (efeito reflexão) - FEA/USP

Quadro 5 - Conjunto de Variáveis Explicativas - Regressão Logística - Hip. 3 (efeito isolamento) - FEA/USP

Quadro 6 - Conjunto de Variáveis Explicativas - Regressão Logística - Hip. 4 (efeito ancoragem) - FEA/USP

Quadro 7 - Conjunto de Variáveis Explicativas - Regressão Logística - Hip. 5 (números brutos x números relativos) - FEA/USP

Quadro 8 - Conjunto de Variáveis Explicativas - Regressão Logística - Hip. 6 (correlação ilusória) - FEA/USP

Quadro 9 - Conjunto de Variáveis Explicativas - Regressão Logística - Hip. 7 (heurística da disponibilidade) - FEA/USP

Quadro 10 - Conjunto de Variáveis Explicativas - Regressão Logística - Hip. 8 (lucro x prejuízo) - FEA/USP

Quadro 11 - Conjunto de Variáveis Explicativas - Regressão Logística - Hip. 9 (heurística da representatividade) - FEA/USP

Quadro 12 - Conjunto de Variáveis Explicativas - Regressão Logística - Hip. 10 (regressão à média) - FEA/USP

Quadro 13 - Conjunto de Variáveis Explicativas - Regressão Logística - Hip. 1 (efeito certeza) - Instituição Financeira

Quadro 14 - Conjunto de Variáveis Explicativas - Regressão Logística - Hip. 2 (efeito reflexão) - Instituição Financeira.

Quadro 15 - Conjunto de Variáveis Explicativas - Regressão Logística - Hip. 3 (efeito isolamento) - Instituição Financeira

Quadro 16 - Conjunto de Variáveis Explicativas - Regressão Logística - Hip. 4 (efeito ancoragem) - Instituição Financeira

Quadro 17 - Conjunto de Variáveis Explicativas - Regressão Logística - Hip. 5 (números brutos x números relativos) - Instituição Financeira

Quadro 18 - Conjunto de Variáveis Explicativas - Regressão Logística - Hip. 6 (correlação

ilusória) - Instituição Financeira.

Quadro 19 - Conjunto de Variáveis Explicativas - Regressão Logística - Hip. 7 (heurística da disponibilidade) - Instituição Financeira . 
Quadro 20 - Conjunto de Variáveis Explicativas - Regressão Logística - Hip. 8 (lucro x prejuízo) - Instituição Financeira

Quadro 21 - Conjunto de Variáveis Explicativas - Regressão Logística - Hip. 9 (heurística da representatividade) - Instituição Financeira

Quadro 22 - Conjunto de Variáveis Explicativas - Regressão Logística - Hip. 10 (regressão à média) - Instituição Financeira

Quadro 23 - Compêndio dos Principais Resultados 


\section{LISTA DE TABELAS}

Tabela 1 - Estatísticas do Teste KPSS para a Série Temporal da Questão 8 .......................... 76

Tabela 2 - Exemplo de Matriz de Confusão para um Dado Ponto de Corte ........................... 84

Tabela 3 - Percentis da Variável Idade para os estudantes da FEA/USP ............................... 90

Tabela 4 - Resultado da Regressão Logística - Hip. 1 (efeito certeza) - FEA/USP ............... 95

Tabela 5 - Resultado da Regressão Logística - Hip. 2 (efeito reflexão) - FEA/USP ............. 97

Tabela 6 - Resultado da Regressão Logística - Hip. 3 (efeito isolamento) - FEA/USP....... 100

Tabela 7 - Resultado da Regressão Logística - Hip. 4 (efeito ancoragem) - FEA/USP....... 102

Tabela 8 - Resultado da Regressão Logística - Hip. 5 (números brutos x números relativos) -

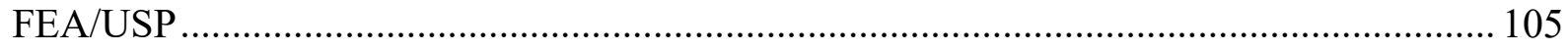

Tabela 9 - Resultado da Regressão Logística - Hip. 6 (correlação ilusória) - FEA/USP..... 108

Tabela 10 - Resultado da Regressão Logística - Hip. 7 (heurística da disponibilidade) -

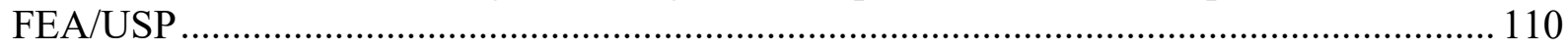

Tabela 11 - Resultado da Regressão Logística - Hip. 8 (lucro x prejuízo) - FEA/USP ....... 113

Tabela 12 - Resultado da Regressão Logística - Hip. 9 (heurística da representatividade) -

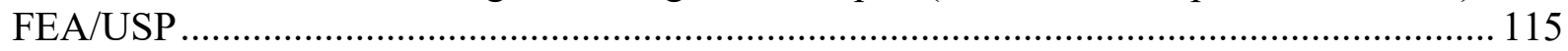

Tabela 13 - Resultado da Regressão Logística - Hip. 10 (regressão à média) - FEA/USP.. 117

Tabela 14 - Percentis da Variável Idade para os analistas da Instituição Financeira ............ 120

Tabela 15 - Resultado da Regressão Logística - Hip. 1 (efeito certeza) - Instituição

Financeira

Tabela 16 - Resultado da Regressão Logística - Hip. 2 (efeito reflexão) - Instituição

Financeira

Tabela 17 - Resultado da Regressão Logística - Hip. 3 (efeito isolamento) - Instituição

Financeira

Tabela 18 - Resultado da Regressão Logística - Hip. 4 (efeito ancoragem) - Instituição

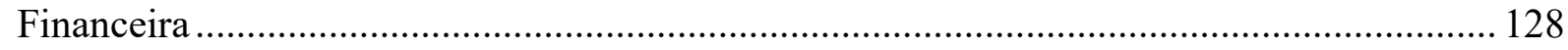

Tabela 19 - Resultado da Regressão Logística - Hip. 5 (números brutos x números relativos)

- Instituição Financeira

Tabela 20 - Resultado da Regressão Logística - Hip. 6 (correlação ilusória) - Instituição

Financeira

Tabela 21 - Resultado da Regressão Logística - Hip. 7 (heurística da disponibilidade) -

Instituição Financeira

Tabela 22 - Resultado da Regressão Logística - Hip. 8 (lucro x prejuízo) - Instituição

Financeira

Tabela 23 - Resultado da Regressão Logística - Hip. 9 (heurística da representatividade) -

Instituição Financeira

Tabela 24 - Resultado da Regressão Logística - Hip. 10 (regressão à média) - Instituição

Financeira 


\section{LISTA DE FIGURAS}

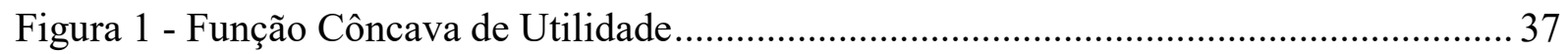

Figura 2 - Um Exemplo de Função de Valor Hipotética.......................................................... 38

Figura 3 - Método Científico Hipotético-Dedutivo............................................................... 56

Figura 4 - Série Temporal dos Resultados do Exercício (Questão 8) .................................... 76

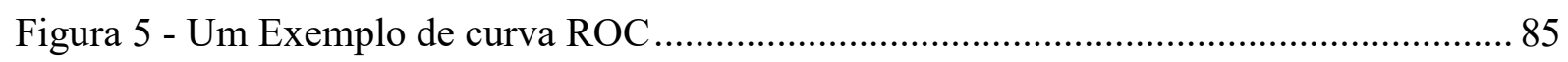

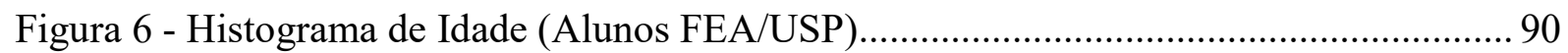

Figura 7 - Histograma de Idade (Profissionais da Instituição Financeira) ............................. 119 


\section{LISTA DE ABREVIATURAS E SIGLAS}

FEA/USP: Faculdade de Economia, Administração e Contabilidade da Universidade de São Paulo

IASB: International Accounting Standards Board

IF: Instituição Financeira Brasileira de Grande Porte

IFRS: International Financial Reporting Standards

MBA: Master in Business Administration

ROC: Receiver Operating Characteristic Curve

S\&P 500: Standard and Poor's 500

VaR: Value at Risk 


\section{SUMÁRIO}

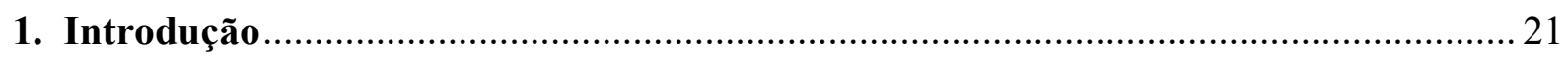

1.1. Questão, Hipótese e Justificativa da Pesquisa ........................................................ 23

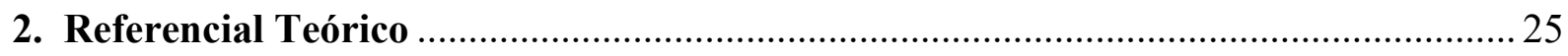

2.1. Uma Introdução ao Seminal Artigo de Tversky e Kahneman de 1974 ............................. 25

2.1.1. A Heurística da Representatividade ................................................................ 26

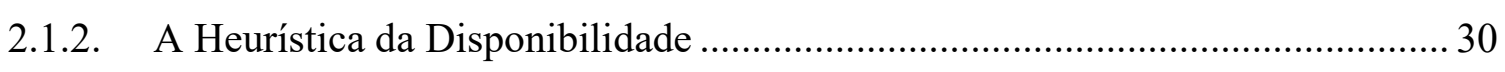

2.1.3. A Heurística do Ajuste e da Ancoragem .......................................................... 33

2.2. Uma Introdução ao Seminal Artigo de Kahneman e Tversky de 1984 ..................... 35

2.2.1. A Função de Valor Hipotética segundo Kahneman e Tversky (1984) ............... 36

2.2.2. Alguns Exemplos de Experimentos que Demonstraram as Limitações dos Axiomas da Invariância e da Dominância.................................................................. 39

2.3. O surgimento dos experimentos em contabilidade financeira................................. 42

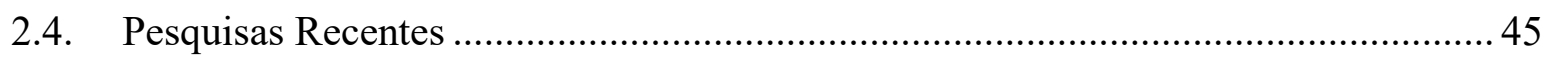

3. Procedimentos Epistemológicos e Metodológicos.......................................................... 53

3.1. Introdução aos Procedimentos Epistemológicos e Metodológicos ........................... 53

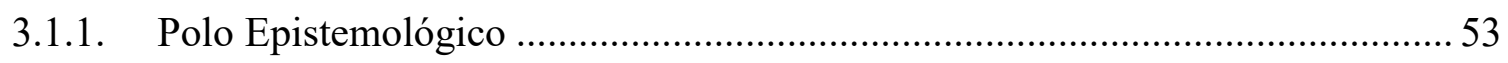

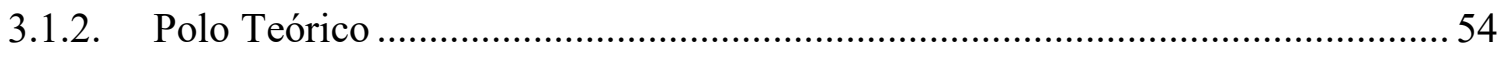

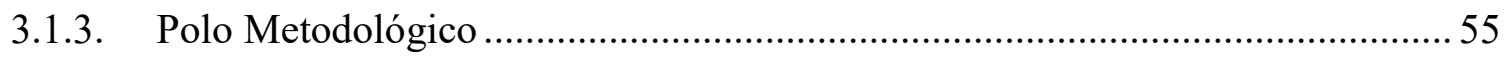

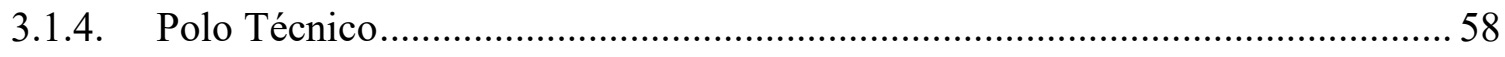

3.1.4.1. Análise Crítica do Questionário - Perfil Social e Acadêmico......................... 59

3.1.4.2. Análise Crítica do Questionário - Perfil de Decisão ....................................... 60

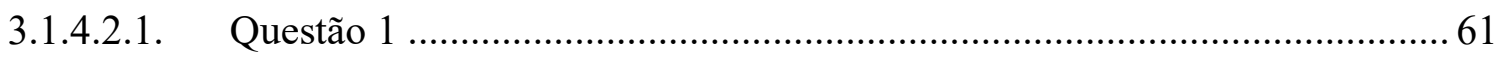

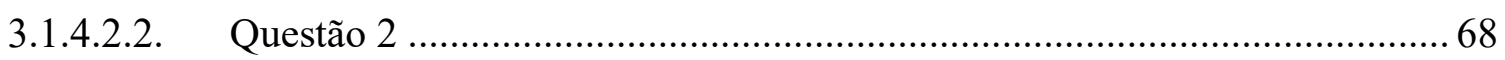

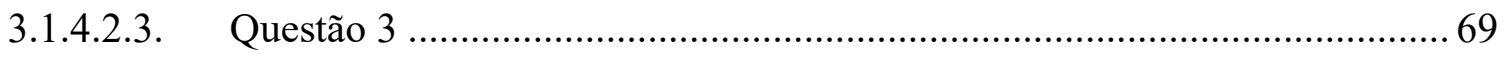

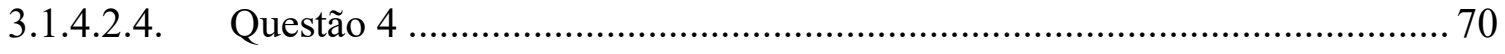

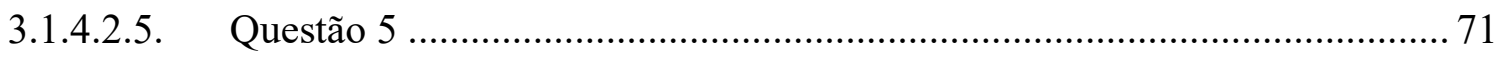

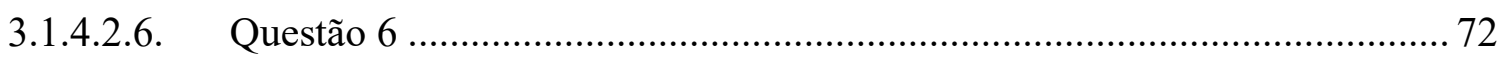

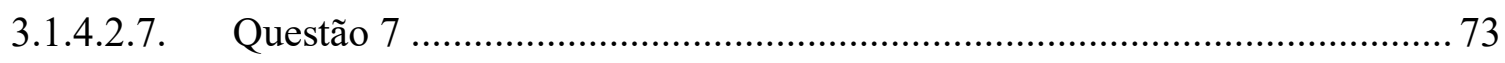

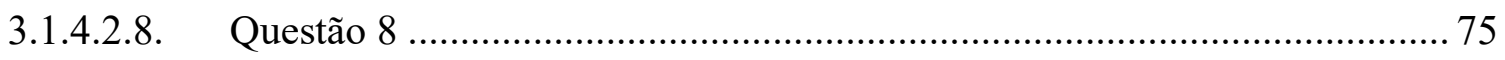

3.1.4.3. Sobre os procedimentos estatísticos aplicados ........................................... 77

3.1.4.3.1. Testes de Hipóteses Aplicados para Análise das Questões 1, 4, 5, 7 e $8 . .788$

3.1.4.3.2. Testes de Hipóteses Aplicados para Análise das Questões 2, 3 e 6......... 799

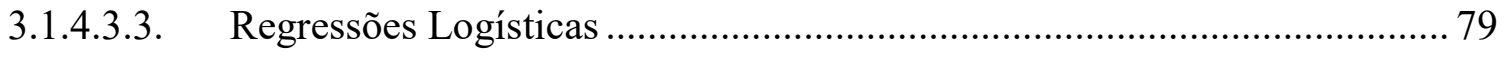

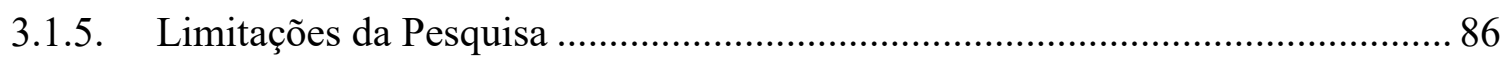


4.1. Estudantes da Faculdade de Economia, Administração e Contabilidade da Universidade de São Paulo.

4.1.1. Perfil dos Respondentes - Estatísticas Descritivas

4.1.2. Questão 1 - Estudantes da Faculdade de Economia, Administração e Contabilidade da Universidade de São Paulo

4.1.3. Questão 2 - Estudantes da Faculdade de Economia, Administração e Contabilidade da Universidade de São Paulo

4.1.4. Questão 3 - Estudantes da Faculdade de Economia, Administração e Contabilidade da Universidade de São Paulo

4.1.5. Questão 4 - Estudantes da Faculdade de Economia, Administração e Contabilidade da Universidade de São Paulo

4.1.6. Questão 5 - Estudantes da Faculdade de Economia, Administração e Contabilidade da Universidade de São Paulo

4.1.7. Questão 6 - Estudantes da Faculdade de Economia, Administração e Contabilidade da Universidade de São Paulo

4.1.8. Questão 7 - Estudantes da Faculdade de Economia, Administração e Contabilidade da Universidade de São Paulo

4.1.9. Questão 8 - Estudantes da Faculdade de Economia, Administração e

Contabilidade da Universidade de São Paulo

4.2. Profissionais de uma Grande Instituição Financeira do Brasil

4.2.1. Perfil dos Respondentes - Estatísticas Descritivas

4.2.2. Questão 1 - Profisssionais de uma Grande Instituição Financeira Brasileira ... 121

4.2.3. Questão 2 - Profissionais de uma Grande Instituição Financeira Brasileira ... 127

4.2.4. Questão 3 - Profissionais de uma Grande Instituição Financeira Brasileira ... 129

4.2.5. Questão 4 - Profissionais de uma Grande Instituição Financeira Brasileira ... 131

4.2.6. Questão 5 - Profissionais de uma Grande Instituição Financeira Brasileira ... 134

4.2.7. Questão 6 - Profissionais de uma Grande Instituição Financeira Brasileira ... 137

4.2.8. Questão 7 - Profissionais de uma Grande Instituição Financeira Brasileira ... 140

4.2.9. Questão 8 - Profissionais de uma Grande Instituição Financeira Brasileira ... 142

4.3. Compêndio dos Principais Resultados Obtidos. 


\section{Introdução}

O paradigma da racionalidade dos agentes econômicos, usado em muitas teorias, vem sendo contestado massivamente por vários pesquisadores, o que pode sugerir que essas teorias não possuem o poder explicativo e preditivo que se espera que elas tenham. É justamente dessa visão que nasceram os estudos em economia e finanças comportamentais. Mais recentemente, tais pesquisas foram expandidas e passaram a fazer parte da agenda dos estudiosos em contabilidade, o que culminou no surgimento da contabilidade comportamental, termo cunhado com vistas a identificar uma linha de pesquisa destinada à aplicação dos estudos comportamentais em contabilidade.

Sem dúvida, os grandes responsáveis pelo surgimento da linha comportamental e seu impacto de como os agentes econômicos tomam suas decisões, foram Kahneman e Tversky, dois psicólogos (com forte formação matemática) que formalizam a teoria dos prospectos, também conhecida como Prospect Theory, na década de 70 e de 80 do século passado. Trabalhos seminais, como os de 1974, 1979 e 1981 lançaram as bases da referida teoria, introduzindo conceitos não abordados pelo paradigma neoclássico da economia, sendo este último fortemente embasado pela escola marginalista.

$\mathrm{Na}$ visão econômica neoclássica, o agente econômico, dispondo de racionalidade e informação completa, toma decisões ótimas que são capazes de maximizar sua utilidade, dado uma restrição orçamentária e uma cesta de bens e serviços. Estes trabalham "na margem" de sua função utilidade, ou seja, este agente é capaz de decidir com base em variações infinitesimais de sua utilidade. Vários livros de microeconomia detalham tais fundamentos e axiomas necessários para se deduzir relações fundamentais. Complementarmente, muitos trabalhos da linha neoclássica foram relaxando algumas hipóteses e testando decisões em condições de assimetria informacional e seleção adversa, como o clássico trabalho de Akerlof (1970). Contudo, o paradigma que embasou essas pesquisas ainda era, predominantemente, o neoclássico.

Kahneman e Tversky (1974, 1979, 1981, entre outros trabalhos) introduziram conceitos como heurísticas e vieses, mostrando várias pesquisas empíricas em que os agentes econômicos eram incapazes de agir racionalmente para tomar suas decisões. Assim sendo, uma robusta teoria foi desenvolvida, buscando explicar como os agentes econômicos tomam suas decisões. 
Diversos experimentos foram feitos em diferentes áreas do conhecimento, como marketing, saúde, na psicologia e até na controladoria e contabilidade. Os trabalhos chegaram a conclusões diversas e interessantes.

Essa tese é mais um fruto das ideias de Kahneman e Tversky. Seu surgimento está intimamente relacionado ao clássico mantra tão difundido nas aulas de contabilidade voltada aos usuários de informações externas: de que a essência deve vigorar sob a forma.

$\mathrm{Na}$ concepção do IASB (International Accounting Standards Board), as demonstrações contábeis devem servir a um propósito, que é o de suprir investidores, credores e demais usuários da informação contábil para que estes possam tomar decisões de forma relevante. Nesse cenário, a essência econômica seria o direcionador da forma como os agentes se informam para tomar suas decisões. Esta visão do IASB é notadamente neoclassicista, tal como vislumbrado em vários conceitos dos pronunciamentos técnicos (por exemplo, o Fair Value).

Entretanto, ao se estudar os vieses e heurísticas propugnados por Kahneman e Tversky, percebe-se, muitas vezes, que a forma na qual a informação é apresentada pode influenciar de maneira substancial como os indivíduos tomam suas decisões. Achados empíricos relatam que todos os indivíduos, a priori, estão sujeitos aos vieses e heurísticas levantados pelos clássicos autores, incluindo os mais qualificados.

Diante dessa discussão de cunho teórico, essa tese buscou analisar criticamente até que ponto algumas premissas podem ser tidas como verdadeiras.

A mesma está orientada sob a seguinte estrutura: no primeiro capítulo, é feita uma breve discussão sobre a questão e hipótese delineadora da pesquisa desenvolvida. Posteriormente, uma justificativa da pesquisa é apresentada, buscando elucidar sua importância para a sociedade e a própria prática contábil per si.

O segundo capítulo aborda o referencial teórico da tese, dividindo-se em dois grandes tópicos: a revisão dos dois principais artigos orientadores da elaboração dessa tese e do levantamento da literatura mais recente, abordando os principais achados empíricos encontrados. 
O capítulo 3 trata sob os procedimentos epistemológicos, metodológicos e técnicos empregados na consecução da pesquisa. No final do capítulo, são expostas as limitações da mesma.

Por sua vez, o capítulo 4 trata da análise dos resultados obtidos, ensejando uma discussão sobre as implicações teóricas e práticas (para a profissão contábil) que eles possuem.

Finalmente, o capítulo 5 envolve as principais conclusões e sugestões de pesquisas futuras a serem efetuadas.

\subsection{Questão, Hipótese e Justificativa da Pesquisa}

Diante do cenário acima exposto, essa tese possui a seguinte questão de pesquisa orientadora do trabalho empírico desenvolvido:

As heurísticas e os vieses influenciam o processo decisório dos indivíduos quando confrontados com os dados oriundos demonstrações financeiras e contábeis publicadas pelas empresas?

Nesta tese, foi adotada a seguinte conjectura: As heurísticas e os vieses influenciam de modo relevante o processo decisório dos indivíduos quando confrontados com os dados oriundos das demonstrações financeiras e contábeis publicadas pelas empresas.

Com o objetivo de garantir que o estudo fosse realizado com indivíduos que fazem uso da informação contábil e que possuam destaque, o trabalho empírico foi desenvolvido junto a alunos da Faculdade de Economia, Administração e Contabilidade da Universidade de São Paulo e profissionais de uma grande instituição financeira nacional.

Ao se trabalhar com alunos de uma das melhores escolas de negócio do Brasil e com profissionais de uma renomada instituição financeira, garante-se que os indivíduos estudados não sejam leigos. Logo, se tais indícios existirem para esses dois grupos, não há como desmerecer que a forma como as informações são apresentadas podem sim influenciar os agentes econômicos. O objetivo dessa tese não é assinalar de modo peremptório de que a 
essência econômica deva ser abandonada. Ao contrário, a essência econômica não pode ser perdida quando na elaboração das demonstrações financeiras. $\mathrm{O}$ objetivo é contribuir verificando se a forma ainda pode influenciar como os usuários tomam suas decisões.

No grau em que isso for verdade, novas políticas podem ser consideradas por meio dos órgãos responsáveis pela criação de regras e pronunciamentos técnicos, tal como o IASB que publica as IFRS (International Financial Reporting Standards).

Assim sendo, o tema apresenta grande relevância prática e pode melhorar a prática contábil, fomentando os órgãos responsáveis pela criação das regras e pronunciamentos técnicos com uma concepção mais holística de como os usuários que usam as informações contábeis decidem.

Com isso, apesar da discussão possuir um cunho teórico que busca confrontar teorias econômicas, sua implicação prática é de grande valia, na medida em que ela pode sugerir uma nova agenda para o IASB, influenciando diretamente também no modus operandi por detrás dos reguladores, que são os responsáveis por garantir que as informações produzidas tenham utilidade aos seus usuários. 


\section{Referencial Teórico}

Esse capítulo da tese aborda o referencial teórico da mesma, detalhando a teoria que a subsidia e achados empíricos observados.

Para tanto, antes de levantar os artigos mais recentes que abordam a questão dos vieses, isto é, fazer uma revisão da literatura, convém explicar com maior precisão e detalhamento sobre as ideias de Tversky e Kahneman expostas em seminal artigo de 1974, Judgement under Uncertainty: Heuristic and Biases, que visa sobre julgamento sob incerteza, discorrendo mais precisamente sobre as heurísticas e vieses oriundos do processo decisório humano.

Não obstante, também antes dos achados empíricos propriamente ditos, será abordado outro artigo seminal de Kahneman e Tversky que influenciaram maciçamente na consecução dessa tese. Tal artigo é intitulado Choices, Values and Frames e data de 1984.

Com isso, primeiramente, discute-se a teoria que embasa a mesma (Prospect Theory) para somente depois ser feita uma análise de achados empíricos recentemente observados.

\subsection{Uma Introdução ao Seminal Artigo de Tversky e Kahneman de 1974}

Em estatística, é comum dizer que um dado estimador apresenta viés quando ele sistematicamente apresenta um comportamento de erro, isto é, quando há um componente de tendência que permite que o processo inferencial seja erroneamente tomado.

A ideia de viés no processo decisório é uma analogia ao clássico conceito oriundo da teoria da inferência amostral. De acordo com Tversky e Kahneman (1974), muitas das decisões nas quais temos de tomar estão intimamente associadas a uma noção de crença. Essa, por sua vez, se materializa na forma de probabilidades subjetivas, calculadas internamente por cada um. Tudo isso é processado com base nos dados disponíveis, e na nossa "capacidade de processamento", fortemente influenciada pelos aspectos cognitivos que subscrevem o ambiente que nos cerca. Esta "capacidade de processamento limitada" nasce do número limitado de princípios heurísticos utilizados por nós na hora de avaliar probabilidades. 
De acordo com os referidos autores, quanto maior clareza aparente na hora de avaliar um fenômeno, mais confiante os indivíduos se sentem com suas estimativas. Contudo, é justamente essa confiança que conduz os sujeitos a vieses, isto é, a erros sistemáticos nos processos decisórios.

Dessa maneira, os respectivos pesquisadores, neste artigo, avaliaram três heurísticas que fundamentam muitos dos vieses explorados pela literatura em diferentes campos do saber. A seguir, serão explorados os mesmos, tecendo os comentários pertinentes.

\subsubsection{A Heurística da Representatividade}

Tversky e Kahneman (1974) realçam que muitas vezes as pessoas recorrem à heurística da representatividade para responder os seguintes tipos de questões:

- Qual é a probabilidade de que um dado evento B se origine de A?

- Qual é a probabilidade desse mesmo evento B produzir A?

Essas perguntas são tipicamente feitas por um usuário das informações financeiras divulgadas pelas empresas. Muitas vezes, um dado usuário, por exemplo, pode estar interessado em tentar atribuir à probabilidade de uma empresa apresentar lucros menores no período subsequente em virtude da composição do passivo.

Como se vislumbra, tal tipo de questão não é trivial, de modo que estimar a probabilidade de modo efetivamente acurado é uma tarefa árdua e complexa (dado que estas variáveis estão correlacionadas com outras tantas). Muitas vezes, as decisões devem ser tomadas em um curto intervalo de tempo, conforme demonstra Cazzari (2013). Esta pressão pode ser ainda maior para que um dado usuário recorra à heurística da representatividade.

Esta, por sua vez, se refere à nossa capacidade de avaliar um fenômeno segundo um grau em que ele é representativo, isto é, o quão próximo ele está de algo análogo. Este procedimento é capaz de conduzir a vieses de decisão, na medida em que ele, muitas vezes, acaba por desconsiderar qualquer probabilidade a priori, tão difundida na teoria da estatística bayesiana. 
Para verificar tão fato, Tversky e Kahneman (1974) fizeram um experimento simples onde descreviam as características de um dado indivíduo e perguntavam qual era sua provável ocupação. No caso em questão, o sujeito era descrito como uma pessoa tímida e retraída, tendo índole doce e sendo organizado. Dentre as alternativas, existiam algumas como bibliotecário e fazendeiro. Apesar de haver um contingente muito maior de fazendeiros do que de bibliotecários nos Estados Unidos da América, pessoas superestimavam à probabilidade do indivíduo ser bibliotecário, desconsiderando qualquer informação sobre a distribuição dos dados a priori.

O teorema de Bayes era violado, mesmo em condições onde as pessoas eram informadas da distribuição apriorística. Notou-se que elas sistematicamente se apoiavam nos estereótipos e na sua representatividade.

No que concerne às informações financeiras divulgadas, analistas poderiam estar tomando decisões com base em ideais comuns de empresas bem estabelecidas apesar dos fatos per si? Essas questões suscitam dúvidas sobre a suposta racionalidade dos agentes. Um dado indivíduo racional não poderia violar o teorema de Bayes de forma tão demonstrada na literatura.

Citando artigo dos mesmos autores de 1973 (artigo b nas referências), estes relataram um aspecto interessante. Quando nenhuma evidência que permita à criação de analogias é dada, as pessoas tendem a responder melhor com os preceitos da probabilidade a priori.

Esse fenômeno também ajuda a levantar dúvidas sobre como as notas explicativas são analisadas em conjunto ao corpo das demonstrações propriamente ditas. As informações apresentadas em um balanço patrimonial estariam sendo vistas de modo desconexo às notas explicativas? Em quais situações, as informações financeiras de outros períodos (informação apriori) seriam desconsideradas na análise das informações do presente?

Tversky e Kahneman (1974) relatam que não é somente na ignorância de distribuições de probabilidade $a$ priori que a heurística da representatividade se revela. Ela também pode fazer um dado indivíduo desconsiderar o tamanho da amostra para fazer seus julgamentos. Mesmo que um dado parâmetro tenha sido estimado com base em uma amostra pequena (cerca de 10 elementos, por exemplo), se este for representativo de uma visão geral sobre o mesmo, ainda 
assim, as pessoas julgarão essa probabilidade de modo análogo se estivesse trabalhando com uma amostra bem maior (1000 observações, por exemplo). Isso fere toda a teoria da amostragem e da consecução de intervalos de confiança para um dado parâmetro. Amostras pequenas tendem a gerar intervalos de confiança para os parâmetros estimados bem maiores. Logo, a probabilidade de haver grandes desvios em relação ao parâmetro estimado é naturalmente maior para amostras pequenas, caso que foi ignorado quando tal assunção era contrária à representatividade de um fenômeno.

No campo da análise das notas explicativas, novas dúvidas surgem: bastaria uma única nota explicativa para que o processo inferencial fosse tomado?

Tal heurística é também observada na concepção errônea de possibilidades. Tversky e Kahneman (1974) justificam seu posicionamento adotando um experimento. Suponhamos que uma moeda honesta é lançada consecutivamente 6 vezes e que cada lançamento seja independente do anterior. Representemos $\mathrm{C}$ como sendo cara e $\mathrm{K}$ como coroa. Os autores relataram que sequências mais alternadas como K-C-K-C-C-K foram tidas como mais prováveis do que sequências que poderiam suscitar um viés na moeda, como C-C-C-C-C-C. $\mathrm{Na}$ prática, se os lançamentos são de fato independentes, ambas as sequências acima denotadas são equiprováveis. A heurística da representatividade, nesse caso, leva às pessoas a acreditar que sequências mais alternadas são mais prováveis.

Novamente, tal ponto acaba por levantar dúvidas sobre aspectos aparentemente desconexos sobre a análise de informações financeiras. Será que a divulgação de informações unicamente positivas em um dado relatório de administração não faz com que os analistas a considerem improváveis?

Essa questão invoca outra dúvida ainda mais provocante: será que uma série de informações estritamente positivas não é tida como mais improvável do que uma série de informações negativas? Até que ponto os indivíduos ponderam as informações atribuídas no corpo das demonstrações financeiras?

Tversky e Kahneman (1974) também comentam que as pessoas são insensíveis à confiabilidade da evidência. Este caso é particularmente importante para o efeito framing positivo ou negativo. Uma descrição muito favorável dos negócios pode conduzir o indivíduo 
a acreditar que um lucro muito alto é condizente, mesmo que as evidências oriundas dos demonstrativos financeiros não assinalem tal situação. Esse aspecto sugere, inclusive, uma agenda de pesquisas que relacionaria a forma como um relatório de administração é escrito e como a mesma ajuda a moldar as expectativas dos agentes, podendo inclusive negar os aspectos factuais. Parece ser de grande importância para a pesquisa contábil tentar mensurar em que grau tal fenômeno se manifesta, com vistas a tentar relatar, se as informações financeiras divulgadas estão sendo efetivamente analisadas.

Os próprios autores relataram em artigo de 1973 (b) de que em um dado experimento, muitas vezes, os participantes demonstram pouco ou nenhum interesse acerca das condições de previsibilidade.

Mais do que verificar qual tipo de informação seria interessante para munir os usuários, a pesquisa contábil deveria estar interessada em ver até que ponto as informações são utilizadas, quais condições motivam o seu uso e qual o perfil de indivíduos que as utilizam de fato.

Outro ponto verificado por Tversky e Kahneman (1974) diz respeito a como se materializa a ilusão da validade. A teoria estatística da correlação assegura que uma previsão pode ser feita de forma mais adequada quando as variáveis explicativas analisadas são independentes entre si, de modo que não haja informações redundantes ou altamente correlacionadas entre si. Contudo, padrões de repetição tendem a fazer com que as pessoas se sintam mais confiantes de suas previsões.

Isso parece ser particularmente importante na análise de notas explicativas no corpo das demonstrações financeiras. É de se esperar que as notas explicativas apresentem um conjunto de informações correlacionadas entre si. Se esta correlação for muito alta, as notas explicativas estarão capturando unicamente um único fenômeno que explicaria vários pontos correlacionados entre si e não vários fenômenos diferentes. Logo, uma dada previsão de um analista poderia estar sendo tomada com base em um único fenômeno.

Finalmente, a heurística da representatividade também ajuda a fomentar explicações causais espúrias sob o efeito da regressão à média, como Tversky e Kahneman (1974) explicaram. Identificada originalmente por Francis Galton em trabalho de 1886, este pesquisador observou que pais mais altos do que a média tendiam a ter filhos menores, ao passo que pais pequenos 
tendiam a ter uma prole maior em altura. De acordo com Galton, a regressão na direção da média era diretamente proporcional ao desvio parental dela. Esse fenômeno também foi observado na análise de desempenho de estudantes. Quando eles iam melhor que a média em uma dada avaliação, a avaliação seguinte era seguida de uma queda no rendimento. $\mathrm{O}$ contrário era igualmente verdadeiro: se ele fosse pior do que a média na primeira, havia uma melhora na segunda.

Conforme se vislumbra, esse fenômeno de regressão à média é extremamente observado em várias situações. Contudo, flutuações naturais em relação à média de uma dada variável aleatória tendem a ser acompanhadas na tentativa humana de achar explicações causais que busquem explicá-la. Muitas vezes, estas são espúrias e o que está se observando, na prática, é uma flutuação natural da variável aleatória em relação à média.

Esse aspecto levanta questões sobre o uso de informações financeiras divulgadas como maneira de encontrar explicações causais para um dado comportamento de variação no lucro, por exemplo. Contudo, verificar se a explicação é espúria não necessariamente é algo trivial. Logo, o uso de teorias pode ajudar a superar essa dificuldade.

\subsubsection{A Heurística da Disponibilidade}

Tversky e Kahneman (1974) explanam que outra heurística comumente evocada para se estimar a probabilidade ou a frequência de um evento é a da disponibilidade. Essa representaria a facilidade com que fatos ou ocorrências podem ser trazidos à mente. Por exemplo, se uma grande empresa está passando por dificuldades de governança, as pessoas tendem a superestimar a probabilidade de que demais empresas venham a incorrer em problemas análogos, mesmo que não haja nenhum indício no corpo das demonstrações financeiras de tal fato.

Os autores explicam que a heurística da disponibilidade é responsável por vários outros vieses observados na literatura. A seguir, os mesmos se encontram explicados:

a) Vieses devido à recuperabilidade das ocorrências: diz respeito à facilidade de recuperar eventos pertencentes a uma denominada classe. Se os indivíduos estão sendo continuamente informados sobre escândalos de governança, estes podem tender a 
superestimar a probabilidade de que outras empresas apresentem problemas similares, sendo mais rigorosos na análise do conjunto de demonstrações financeiras, por exemplo. Logo, o viés da recuperabilidade também é fortemente influenciado pela proeminência dos fatos.

b) Vieses devidos à efetividade de um ajuste de busca: diz respeito à facilidade da capacidade humana de fazer buscas sob diferentes condições. Para ilustrar melhor esse viés, convém explanar experimento relatado por Kahneman e Tversky (1973a). Um grupo de participantes foi indagado sobre qual classe é maior, a de palavras que começam com a letra $r$ ou que possuem esta na terceira posição. Na língua inglesa, a letra $r$ é mais frequente na terceira posição do que na primeira. Contudo, há uma maior efetividade de busca para a primeira letra, fazendo com que muitos indivíduos aleguem que é mais comum a letra $\mathrm{r}$ na primeira posição. $\mathrm{Na}$ análise de demonstrações financeiras, esse viés pode se manifestar na capacidade de indivíduos associarem certas classes de contas a um tipo de negócio propriamente dito, isto é, para alguns indivíduos pode parecer mais intuitivo associar informações de derivativos, por exemplo, a certos negócios. Isso é particularmente importante, pois informações referentes à derivativos podem ter a atenção desses sujeitos somente em negócios em que eles conseguem atribuir importância prévia, mesmo que os dados não colaborem com essa posição;

c) Vieses de imaginibilidade: muitas vezes, os indivíduos são obrigados a construir cenários para estimar frequência de classes. Um clássico experimento é citado por Tversky e Kahneman (1974). Nele, as pessoas foram questionadas qual era o número máximo de comitês com $k$ indivíduos que poderiam ser feitos de 10 pessoas diferentes, com $k$ maior ou igual a 2 e menor ou igual a 8 . Da teoria das combinações, sabemos que a solução para o problema proposto é tal que:

Número Máximo de Comitês $=\sum_{k=2}^{8}\left(\begin{array}{c}10 \\ k\end{array}\right)$

Em que:

$$
\left(\begin{array}{l}
n \\
k
\end{array}\right)=\frac{n !}{(n-k) ! k !}
$$


É o coeficiente binomial e representa, neste exemplo, quantos comitês com $k$ indivíduos podem ser feitos de $n$ indivíduos.

Não obstante, sabemos que o coeficiente binomial apresenta a seguinte propriedade:

$\left(\begin{array}{l}n \\ k\end{array}\right)=\left(\begin{array}{c}n \\ n-k\end{array}\right)$

Logo, não é difícil notar que a seguinte função é simétrica:

$f(k)=\left(\begin{array}{c}10 \\ k\end{array}\right), \operatorname{com} k=2,3 \ldots, 8$

Ademais, verifica-se que seu ponto de máximo ocorre quando $k$ é igual a 5 , sendo possível de ajustá-la continuamente na forma de um sino (com baixo erro quadrático).

Apesar de todas essas considerações, Tversky e Kahneman (1974) notaram que pessoas leigas em análise combinatória tinham mais facilidade em construir cenários formados de comitês com menos pessoas, de tal sorte que a função $f(k)$ foi vista como sendo monotonicamente decrescente.

A capacidade de construir cenários pode possuir grande importância nas notas explicativas que evidenciam informações sobre simulações de estresse e Value at Risk (VaR), tipicamente feitas por simulações de Monte Carlo. Dependendo da capacidade de imaginar cenários, tanto o elaborador quanto o leitor da nota explicativa pode estar erroneamente analisando as probabilidades de acontecerem os eventos;

d) Correlação ilusória: de acordo com Tversky e Kahneman (1974), a frequência com que dois eventos ocorram concomitantemente pode ser facilmente superestimada se há uma força de ligação associativa entre os mesmos. Em termos de análise de demonstrações financeiras, pode-se imaginar um cenário em que o aumento dos lucros de uma instituição financeira vem sendo acompanhado de um aumento na conta de depósitos à vista. Na realidade, esse aumento dos lucros poderia estar oriundo da conjuntura da taxa de juros de um período e não do aumento de depósitos à vista. Contudo, a correlação 
entre os fenômenos pode sugerir que eles são intimamente relacionados. Logo, erros sistemáticos podem derivar desse tipo de julgamento.

\subsubsection{A Heurística do Ajuste e da Ancoragem}

De acordo com Tversky e Kahneman (1974), muitas vezes, as pessoas fazem estimativas com base em um valor inicial que vai sendo ajustado para produzir a resposta final. Os vieses decisórios começam a ocorrer quando os diferentes pontos de partida passam a produzir diferentes resultados. Isso é o que os autores chamam de heurística da ancoragem.

Visando a explicar o fenômeno do ajuste incompleto, Tversky e Kahneman (1974) explanam um interessante experimento, onde se pediu para que participantes estimassem o percentual do número de países africanos nas Nações Unidas. O problema é que inicialmente rodava-se uma roda da fortuna onde saia um percentual aleatório. A pessoa, então, era obrigada a estimar a respectiva quantidade de países, dizendo se ele era maior ou menor ao número obtido na roda da fortuna. Os autores observam que as estimativas medianas da porcentagem foram de $25 \%$ e $45 \%$ para grupos que receberam $10 \%$ e $65 \%$ na roda da fortuna, respectivamente.

No campo da análise das demonstrações financeiras, novas questões podem surgir a partir desse fato. O lucro de um período anterior seria capaz de determinar o que é um lucro "bom" ou "ruim" para o próximo período? Se pontos de partida diferentes moldam estimativas diferentes, esse fenômeno ocorrerá.

A heurística da ancoragem não se revela unicamente quando um ponto de partida é necessariamente dado. A própria ordem em que uma operação é feita pode influenciar maciçamente a estimativa feita, conforme salienta Tversky e Kahneman (1974).

Esse ponto é particularmente importante para a agenda de pesquisa contábil, pois pode indicar de que a ordem em que as notas explicativas são divulgadas pode impactar numa eventual estimativa da probabilidade da saúde financeira de uma empresa.

A ancoragem não é noticiada unicamente no viés acima exposto. Ela também revela uma faceta sobre um comportamento humano quando lidamos com eventos conjuntivos e 
disjuntivos. Embasando-se em trabalhos de Bar-Hillel (1973) e de Cohen et al. (1972), Tversky e Kahneman (1974) explicam que pessoas tendem a superestimar a probabilidade de eventos conjuntivos e subestimar as oriundas de eventos disjuntivos.

Para um evento conjuntivo se consubstanciar, é necessário que cada um dos eventos que o compõe ocorra. Mesmo que a probabilidade de ocorrência de cada um dos eventos analisados individualmente seja alta, a probabilidade conjuntiva de todos pode ser estritamente baixa. Se este é superestimado, Tversky e Kahneman (1974) relatam que isso pode guiar a um otimismo exacerbado na ocorrência do respectivo evento.

Por sua vez, para que um evento disjuntivo ocorra, basta que um dos eventos que o compõe ocorra. Mesmo que a probabilidade de cada um dos eventos ocorrer seja individualmente muito baixa, a probabilidade de ao menos um ocorrer pode ser significativa. Assim sendo, em situações de risco, onde basta um componente falhar para comprometer todo o sistema, esse viés pode se manifestar, na medida em que as pessoas podem não mensurar adequadamente sua real probabilidade, subestimando-o.

Esse tipo de viés está associado à heurística da ancoragem, pois muitas vezes, um dado indivíduo pode estimar a probabilidade conjuntiva ou disjuntiva com base unicamente na probabilidade do primeiro evento da cadeia, levando a erros de decisão sistemáticos.

Esse aspecto também pode trazer implicações profundas na análise do corpo de demonstrações financeiras, pois se cada nota explicativa for analisada de modo desconexo, a probabilidade de união ou intersecção de eventos pode ser erroneamente estimada.

Por fim, vale a pena discorrer brevemente sobre a ancoragem na avaliação da distribuição de probabilidades subjetivas. Muitas vezes, os agentes estimam um valor tal que acreditam que não será superado em, digamos, por exemplo, 95\% dos casos. Se isto for verdade, os valores reais não podem superar o referido valor estimado em não mais do que 5\%. Tversky e Kahneman (1974) expõem que muitas vezes as distribuições de probabilidades subjetivas propostas por respondentes fugiram em muito da calibragem apropriada.

Contudo, o maior problema não nasce oriundo do fato acima exposto, haja visto que muitas vezes é extremamente complicado precisar o comportamento de uma dada variável aleatória. 
O maior problema ocorre na forma como a mesma questão é exposta. Pode-se indagar a um determinando indivíduo a mesma de dois modos:

(i) Solicitando que o respondente selecione valores que correspondam a percentuais específicos de probabilidades;

(ii) Pedindo-se que o respondente informe qual é a probabilidade de que um dado valor especificado seja excedido;

Apesar de ambas as questões refletirem concepções análogas sob a distribuição de probabilidade subjetiva de um sujeito, Tversky e Kahneman (1974) relatam que estudos apontaram que os dados podem diferir severamente, na medida em que a questão (ii) sugere uma âncora, isto é, um ponto de ajuste a partir do número fornecido, de tal sorte que a segunda questão tende a gerar probabilidades menos extremas do que a questão (i).

\subsection{Uma Introdução ao Seminal Artigo de Kahneman e Tversky de 1984}

Indubitavelmente, os agentes econômicos tomam decisões todos os dias, sendo que algumas envolvem risco e outras não. Assim sendo, conforme Kahneman e Tversky (1984) expõem, é natural que vários campos do saber humano tenham começado a explorar como as pessoas tomam as decisões. De acordo com os referidos autores, pode-se dizer que as teorias foram divididas em majoritariamente dois tipos:

- Teorias Normativas: dizem respeito à natureza da racionalidade e da lógica da decisão;

- Teorias Descritivas: dizem respeito à como as decisões são de fato tomados pelos indivíduos.

Dentre as teorias normativas, destaca-se a teoria da decisão de Von Neumann e Morgenstern (1947) levemente abordada na introdução dessa tese. Essa tese não compartilha da visão desses referidos pensadores, por julgar que os princípios axiomáticos do processo decisório por eles feitos, não são adequados para explanar de como as decisões são efetivamente tomadas. 
O próprio trabalho de Kahneman e Tversky (1984), explorado nessa seção, apresenta exemplos empíricos que refutam princípios da escolha racional, como a dominância e a variância.

Conforme explicam Kahneman e Tversky (1984), a dominância pode ser vista da seguinte forma: suponha que existam dois bens, A e B. Se A é no mínimo tão bom quanto B em todos os aspectos e concomitantemente é melhor do que B em ao menos um aspecto, então A domina B.

Por sua vez, a invariância diz que a ordem de preferência não pode depender da forma como são descritas. A seguir, serão explicados como funciona uma função de valor hipotética propugnada por Kahneman e Tversky (1984) e exemplos de experimentos clássicos que ajudaram a refutar a veracidade da dominância e da invariância como direcionadores no processo decisório.

\subsubsection{A Função de Valor Hipotética segundo Kahneman e Tversky (1984)}

Segundo Kahneman e Tversky (1984), as pessoas possuem uma interessante propriedade na forma como tomam decisão em situações de risco. Elas são avessas ao risco no domínio dos ganhos, porém são atraídas pelo mesmo no domínio das perdas.

A primeira parte acima não foi algo introduzida pelos estudos de Kahneman e Tversky. De fato, os próprios autores citam trabalho de Daniel Bernoulli, publicado no século XVIII, que buscava explicar porque as pessoas eram avessas ao risco e porque esta diminuía com o aumento da riqueza. Bernoulli era particularmente intrigado porque as pessoas preferiam um ganho certo em uma dada aposta, mesmo que a esperança do valor ganho de uma aposta fosse maior.

Kahneman e Tversky (1984) mostram que Bernoulli propôs que existiria uma função côncava crescente de dinheiro que mensuraria o valor subjetivo (utilidade) de um indivíduo. Assim sendo, assuma que $w$ represente a riqueza e que $U(w)$ seja a função côncava. Esta seria assim dada: 


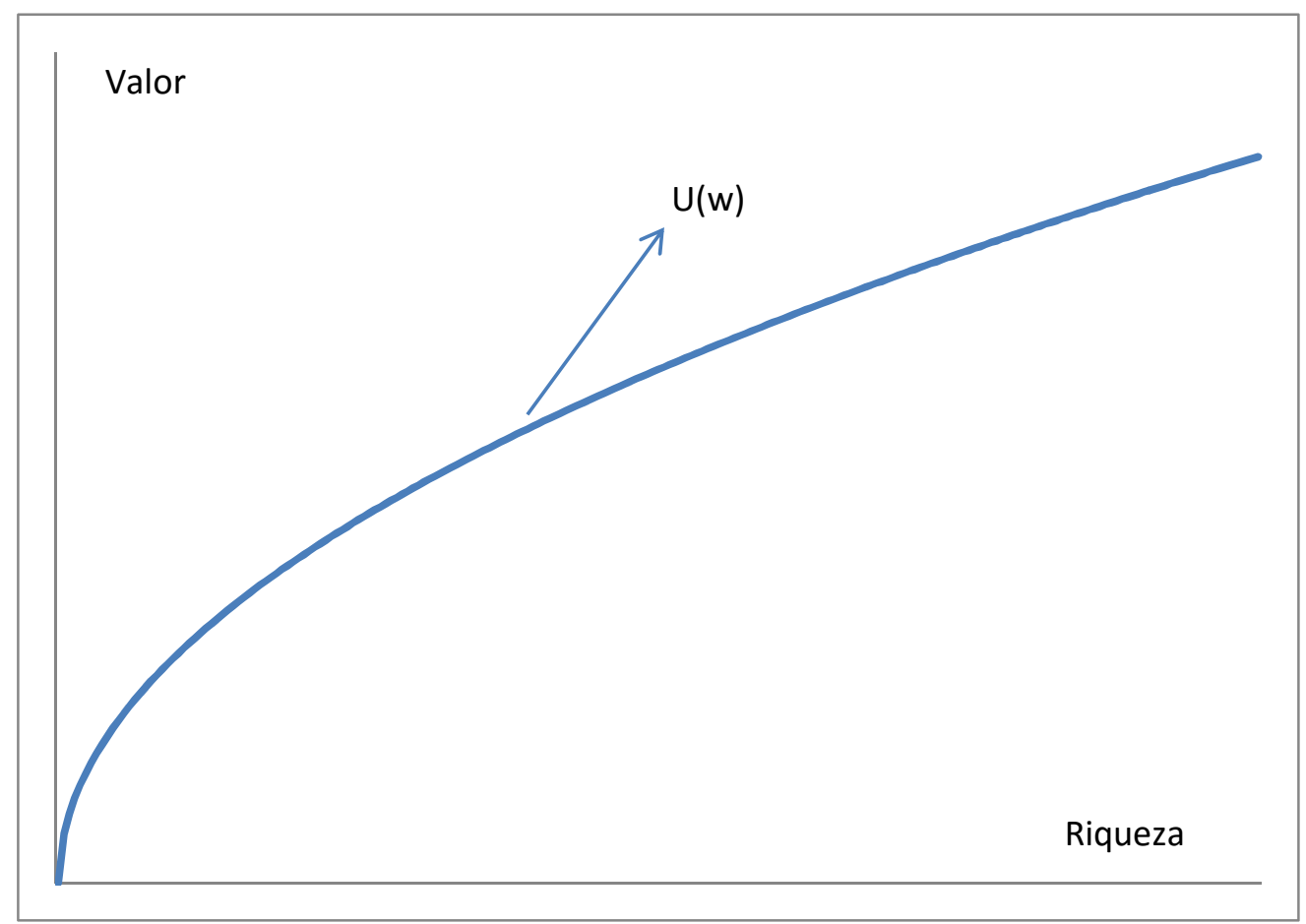

Figura 1 - Função Côncava de Utilidade

Uma importante propriedade desse tipo de função é que ela apresenta sua segunda derivada sendo negativa, isto é, apesar de ser crescente, ela está desacelerando. Isso implica que a diferença de utilidade entre 50 e 100 dólares, por exemplo, é maior do que entre 1050 e 1000 dólares.

Contudo, Kahneman e Tversky (1984) relatam que as pessoas não pensam em termos de riqueza totais. $\mathrm{Na}$ verdade, essa apresentação seria irreal, na medida em que as pessoas não pensam normalmente nos resultados relativamente pequenos de seus estados de riqueza, mas sim em termos de ganhos, perdas ou manutenção do status quo. Assim sendo, os autores explicam que a análise psicofísica dos resultados deve ser aplicada antes a ganhos e perdas do que a recursos totais. Esta seria a hipótese fundamental, na visão dos autores, que embasaria toda a Prospect Theory.

Os autores afirmam que as diferentes medições, tanto de introspecção, quanto psicofísicas, sugerem que a utilidade é de fato uma função côncava do tamanho do ganho. Contudo, Kahneman e Tversky (1984) falam que essa generalização também se aplica às perdas. Logo, a diferença de utilidade entre uma perda 50 e 100 dólares é maior do que a diferença entre uma perda de 1050 e de 1000 dólares. 
Kahneman e Tversky (1984) explicam que a atração pelo risco no campo das perdas foi comprovada por diversos pesquisadores, tais como Fishburn e Kochenberger (1979), Hershey e Schoemaker (1980), Payne et al. (1980), Slovic et al. (1982), Erakar e Sox (1981), Fischhoff (1983), Tversky (1977), dentre outros.

Essa atração foi confirmada em experimentos simples, onde o sujeito preferia apostar num jogo (mesmo que a esperança de perda fosse alta) do que uma perda certa. Por exemplo, entre optar por uma perda certa de 400 dólares e um jogo com $60 \%$ de probabilidade de perder 1000 dólares ou não perder nada, as pessoas sistematicamente preferiam apostar.

Tal constatação faz com que a função de utilidade, isto é, a função de valor hipotética, seja convexa no domínio das perdas. Juntando isso à concavidade já denotada no campo dos ganhos, se obtém uma função em formato S, tal como Kahneman e Tversky (1984) demonstraram:

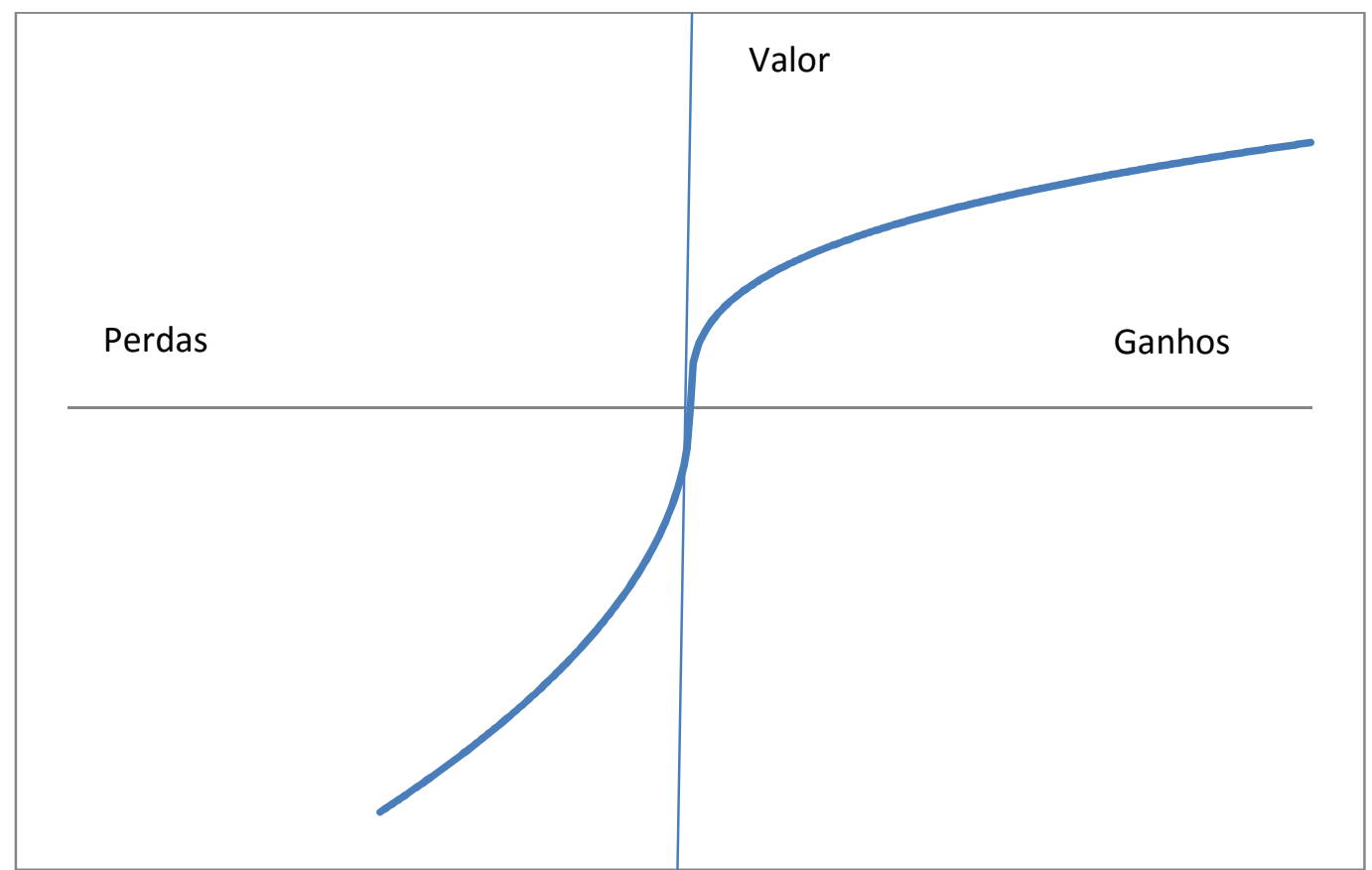

Figura 2 - Um Exemplo de Função de Valor Hipotética

Fonte: Kahneman e Tversky (1984, p.342)

Assim sendo, Kahneman e Tversky (1984) expõem que a função de valor hipotética possui três grandes propriedades:

(i) É definida em termos de ganhos e perdas e não em termos de riqueza total;

(ii) É côncava no domínio dos ganhos e convexa no domínio das perdas; 
(iii) É mais abrupta no domínio das perdas.

Os autores realçam que o item (iii) é particularmente importante, pois ela explicita a propriedade de aversão à perda, isto é, as pessoas são mais avessas a perder certa quantidade $x$ de dinheiro do que ganhar a mesma quantia.

\subsubsection{Alguns Exemplos de Experimentos que Demonstraram as Limitações dos Axiomas da Invariância e da Dominância}

Baseado em trabalho de 1981 dos mesmos autores, Kahneman e Tversky (1984) citam intrigante experimento onde a ordem em que as informações foram colocadas mudaram substancialmente a decisão tomada pelos diferentes agentes.

O experimento descrito nessa tese pode ser encontrado no trabalho de Kahneman e Tversky de 1984. Este se encontra transcrito e traduzido adiante.

Para 152 pessoas, foi feita a seguinte pergunta:

Problema 1: Imagine que os Estados Unidos da América estão se preparando para o surto de uma doença asiática incomum, onde se espera a morte de 600 pessoas. Dois programas alternativos para combater a doença foram propostos. Assuma que as estimativas científicas exatas das consequências dos programas são as seguintes:

Programa A: se este programa for adotado, 200 pessoas serão salvas;

Programa B: se este programa for adotado, há um terço de probabilidade de que as 600 pessoas serão salvas e uma probabilidade de dois terços de que ninguém será salvo.

Kahneman e Tversky (1984) observaram que do total dos 152 indivíduos, 72\% das pessoas preferiram o programa A ao programa $\mathrm{B}$.

Por sua vez, a mesma pergunta foi feita para outro grupo de 155 pessoas. Contudo, os programas foram assim descritos (algumas pessoas responderam as duas perguntas).

Programa C: se este programa for adotado, 400 pessoas irão morrer; 
Programa D: se este programa for adotado, há um terço de probabilidade que ninguém irá morrer e dois terços de probabilidade de que as 600 pessoas morrerão.

Conforme se noticia, é fácil verificar que o programa $\mathrm{C}$ é estritamente idêntico em termos de conteúdo informacional ao programa $\mathrm{A}$, ao passo em que o programa $\mathrm{D}$ também é idêntico ao programa B. Não há mudança no conteúdo per si. O que mudou severamente foi a forma de como a questão foi abordada.

Entretanto, dos 155 indivíduos que responderam a segunda pergunta, somente $22 \%$ preferiram o programa C. Os outros $78 \%$ escolheram o programa D. Logo, a forma como as alternativas foram dadas mudou severamente a maneira de como as pessoas decidem. Isto é, Kahneman e Tversky (1984) falaram que estes seriam o que se denominou framing of outcomes (quadros de saída), contrariando totalmente a visão axiomática da racionalidade humana da invariância das preferências.

Surpreendentemente, algumas pessoas responderam as duas perguntas e deram respostas claramente conflitantes. Segundo os autores, tal diferença se manifestou devido às diferenças de estados subjacentes à forma como os programas foram escritos. Enquanto o primeiro caso pressuponha uma noção de "vidas salvas", o segundo trazia a noção de "vidas perdidas". Esta simples diferença foi suficiente para os indivíduos fossem majoritariamente avessos ao risco na primeira formulação e atraídos pelo mesmo na segunda.

Kahneman e Tversky (1984) explicam que esse tipo de fenômeno se mostra comum mesmo entre indivíduos sofisticados. Estes efeitos de formulação, assim sendo, podem atingir todos os indivíduos.

Se for assumido que um determinado usuário está lendo as demonstrações financeiras publicadas por uma dada empresa para decidir se vale a pena comprar ou não uma ação da respectiva companhia, os framing of outcomes parecem nutrir uma grande importância, na medida em que a forma como uma dada nota explicativa é escrita, por exemplo, pode fomentar diferentes decisões. Contudo, uma menção precisa ser feita: diferentemente do clássico experimento de Kahneman e Tversky (1984), onde o assunto são vidas salvas (afetando ética e psicologicamente os sujeitos), indivíduos podem não ser tão criteriosos em suas decisões com casos hipotéticos. Assumir que se possui um dinheiro a investir é diferente 
do que investir seu próprio dinheiro, de modo que um sujeito experimentado pode não se esforçar com o mesmo esmero que faria se estivesse fazendo com seu dinheiro real. Assim sendo, é importante que se criem artifícios que visem a incentivar uma participação com esmero por parte do experimentado. Tal aspecto será melhor detalhado quando da explicação da metodologia a ser empregada nessa tese.

Dessa maneira, a importância do efeito framing não pode e nem deve ser subestimada, pois ela sugere que os relatórios contábeis podem ser direcionadores de impactos no mercado financeiro, mas não pelo seu conteúdo informacional, e sim pela forma como o mesmo é redigido.

A seguir, serão tecidos comentários sobre outro experimento descrito por Kahneman e Tversky (1984) que realçam a limitação dos princípios da dominância e invariância testados conjuntamente. Novamente, tal experimento será reproduzido nessa tese para fins de análise de implicações teóricas oriundas do mesmo.

Para 86 indivíduos, foi solicitado que se escolhesse entre duas alternativas:

Alternativa A: $25 \%$ de chance de ganhar $\$ 240$ e $75 \%$ de chance de perder $\$ 760$;

Alternativa B: $25 \%$ de chance de ganhar $\$ 250$ e $75 \%$ de chance de perder $\$ 750$.

Como os autores prontamente observam, é trivial perceber que a alternativa B domina a A. De fato, de todos os 86 indivíduos, todos preferiram B a A.

Agora considere o seguinte problema solicitado para que 150 sujeitos respondessem.

Problema 2: Imagine que você enfrenta o seguinte par de situações para serem decididas concomitantemente. Primeiro, examine ambas as decisões, então indique as opções em que você prefere.

Decisão 1 - Escolha entre:

C. Um ganho certo de $\$ 240$;

D. $25 \%$ de chance de ganhar $\$ 1000$ e $75 \%$ de chance de ganhar nada. 
Decisão 2 - Escolha entre:

E. Uma perda certa de $\$ 750$;

F. $75 \%$ de chance de perder $\$ 1000$ e $25 \%$ de chance de perder nada.

Kahneman e Tversky (1984) relatam que na decisão 1, 84\% dos sujeitos escolheram a alternativa $\mathrm{C}$, ao passo que somente $16 \%$ escolheram a D. Por sua vez, na questão $2,87 \%$ escolheram a alternativa $\mathrm{F}$, em detrimento de $13 \%$ que escolheram a alternativa $\mathrm{E}$.

Agora, é importante se lembrar que o problema solicitava que ambas as decisões fossem tomadas em conjunto. Se um indivíduo escolheu o par dado pelas alternativas $\mathrm{C}$ e $\mathrm{F}$, ele chegou exatamente na alternativa A descrita anteriormente, isto é, 25\% de ganhar $\$ 240$ e $75 \%$ de chance de perder $\$ 760$. Por sua vez, se o par escolhido fosse o D e E, ele chegaria a situação da alternativa $\mathrm{B}$, isto é, $25 \%$ de chance de ganhar $\$ 250$ e $75 \%$ de chance de perder $\$ 750$.

Kahneman e Tversky (1984) notaram que somente 3\% dos indivíduos escolheram concomitantemente as alternativas $\mathrm{D}$ e $\mathrm{E}$, ao passo que $73 \%$ escolheram o par C e F. Logo, as pessoas, em sua maioria, escolheram um par que era claramente dominado pelo outro.

Esse experimento simples levanta questões que podem ter aplicação direta na análise de notas explicativas de demonstrações financeiras. Se as notas explicativas forem analisadas individualmente e as decisões forem também tomadas individualmente, isso pode levar, inevitavelmente, a situações estranhas, como a descrita por Kahneman e Tversky (1984).

\subsection{O surgimento dos experimentos em contabilidade financeira}

Como Libby et al. (2002) explicam, nem sempre experimentos em contabilidade financeira foram necessariamente bem vistos. Dentre as críticas elaboradas no começo, Maines (1995) e Berge, Dickhaut e McCabe (1995) citam:

- A crença da irrelevância no comportamento individual nos mercados, nas quais as forças competitivas eliminariam esses "erros individuais";

- A pobreza dos métodos de pesquisa propriamente ditos; 
- A falta de teoria econômica ou psicológica que previsse os efeitos e os mecanismos nos quais elas ocorrem;

- O fracasso em capturar aspectos relevantes das decisões, em especial os atributos do tomador de decisões e as características institucionais.

Libby et al. (2002) explicam que foi no meio dos anos 90 que ocorreu um renascimento dessa modalidade de pesquisa. Na visão dos autores, os seguintes fatores contribuíram para esse fenômeno:

1. Mudanças na visão da eficiência dos mercados: baseados majoritariamente em Fama (1970), muitos pesquisadores passaram a ter a crença de que se uma pequena fração de investidores são suficientemente sofisticados para responder apropriadamente à informação contábil, eles irão competir entre eles mesmos para colocar o preço de ativos mobiliários igual a seus valores esperados. Nesse sentido, o mercado se tornaria um "jogo justo", onde mesmo os investidores não sofisticados estariam protegidos pela eficiência informacional dos preços. Contudo, Libby et al. (2002) explanam que mesmo nos anos 1980 e 1990, vários estudos começaram ilustrar ineficiências no mercado. Dentre os exemplos, podem-se citar Sloan (1996), Frankel e Lee (1998), Swaminathan (2000), DeBondt e Thaler (1990), dentre vários outros. Indubitavelmente, conforme os autores explanam, parece que há um número cada vez maior de pesquisadores que duvidam da hipótese de eficiência do mercado, mesmo em sua forma mais fraca (onde o mercado responde eficientemente para informações contidas em preços passados);

2. A vantagem comparativa dos experimentos em contabilidade financeira: de acordo com Libby et al. (2002), experimentos são adequados para a tarefa de determinar sob quais situações e processos fenômenos específicos surgem. Tal fato acontece, pois em um cenário de pesquisa construído, um indivíduo pode manipular as variáveis independentes, controlar outras variáveis influenciadoras mantendo-as constantes ou criando cenários aleatórios, além de mensurar o processo de intervenção que afetam os resultados finais;

3. Avanços teóricos em psicologia, finanças e economia: de acordo com Libby et al. (2002), os experimentos em contabilidade financeira podem se assentar em teorias psicológicas bem desenvolvidas em julgamento e tomada de decisão. Sem dúvida, a ideia de que os tomadores de decisão possuem uma capacidade limitada de retirar, manter e processar as informações, colabora a visão de que seus julgamentos estão longe de serem racionais (Simon, 1957). Os autores comentam que o papel das heurísticas na tomada de decisões 
(Kahneman e Tversky, 1974) tiveram grande papel no desenvolvimento teórico da área, assim como os modelos psicológicos de risco (Kahneman e Tverskt, 1979) e ambigüidade (Einhorn e Hogarth, 1986) que mostram que os indivíduos respondem aos riscos e recompensas em vários modos que desviam da teoria da utilidade esperada. Libby et al. (2002) relatam vários trabalhos que surgiram. Dentre alguns exemplos, podese citar os de Gervais e Odean (1997) e Odean (1998) que incorporam o excesso de confiança em modelos de trading, o de Barberis et al. (1998) que usam modelos psicológicos para verificar quão bem as pessoas percebem sequências de passeio aleatório em um modelo com investidor representativo;

4. Aspectos institucionais chaves que influenciam na contabilidade financeira: segundo Libby et al. (2002), a pesquisa experimental mais recente em contabilidade financeira tem considerado os aspectos institucionais que permeiam o ambiente, isto é, tem também se focado nas interações entre os indivíduos e as características do ambiente, analisando o conhecimento e as motivações dos usuários e divulgadores de informações.

De modo geral, Libby et al. (2002) criaram uma taxonomia de trabalhos comportamentais em contabilidade financeira a ser explorada adiante. Assim sendo, os trabalhos se dividem nas seguintes categorias de perguntas:

\section{Como os incentivos dos auditores e administradores e a regulação da contabilidade} financeira determinam como os eventos são divulgados? Esta pergunta, alvo de pesquisas também em estudos archival, busca identificar como a subjetividade da medida contábil propicia aos administradores uma maneira de gerenciar resultados. Essa tese não está seguindo essa linha de pesquisa;

2. Como os usuários das informações contábeis interpretam as demonstrações financeiras divulgadas, dado seus conhecimentos da regulação que os governa e de seus incentivos? Esta pergunta pode ser avaliada de diversas maneiras diferentes. Podese investigar como o uso de um método contábil, em detrimento de outro, influencia as estimativas dos investidores. Pode-se adicionalmente analisar como os investidores respondem à divulgação de informações voluntárias ou mesmo às previsões de analistas, ou mesmo como os investidores e analistas usam as propriedades das séries de ganhos para prever ganhos futuros. Contudo, é na subcategoria de questões gerais que subscrevem a fixação funcional que essa tese se enquadra. Nesta categoria de estudos, há indícios de que a divulgação de informações financeiras em uma seção específica ao 
invés de outra, ou mesmo se estará descrita em uma nota explicativa ou outra, influencia na forma como os agentes tomam decisões;

3. Como as respostas dos indivíduos às informações disponíveis afetam o mercado? Esta linha de pesquisa explora como os indivíduos afetam os preços de mercado, investigando até que ponto os preços podem simplesmente serem definidos como a média da crença dos investidores. Essa tese também não segue essa linha;

4. Como as interações estratégicas entre os divulgadores de informações financeiras e os usuários das mesmas afetam o processo de divulgação e os resultados de mercado? Esta vertente de pesquisa busca, fazendo uso principalmente da teoria dos jogos, observar as interações entre os elaboradores e os usuários das informações financeiras. Novamente, não há relação da mesma com essa tese.

A seguir, se encontra uma revisão de literatura de artigos mais recentes publicados que nutrem relação com este trabalho.

\subsection{Pesquisas Recentes}

Conforme discorrido anteriormente, essa seção passará a levantar pesquisas passadas e algumas de suas implicações.

Bailey et al. (2011) examinaram o efeito de vieses comportamentais em investidores de fundos mútuos. Os autores concluíram que investidores que apresentavam grande viés em suas decisões tipicamente tomavam decisões pobres, o que levava a resultados pobres.

Com conclusões relativamente análogas, Kumar e Lim (2008) notaram que o framing influencia as decisões de investimento de investidores individuais. Os autores notaram que os resultados sugeriam que decisões tomadas em separado estavam mais dispostas a terem viés do que aquelas tomadas conjuntamente, tal como já conjecturado na revisão do artigo de Kahneman e Tversky (1974).

Glaser et al. (2007) também relataram a grande presença do efeito framing nas previsões de mercado de ações, mostrando que os resultados das pesquisas são facilmente influenciadas pela modo em que as expectativas de retorno são elucidadas. 
Por sua vez, Avgouleas (2006) recomenda que para se evitar o efeito framing, faz-se necessário prescrições regulatórias das estruturas de promoção dos investimentos. Packin (2013) também concorda que políticas legais podem reduzir efeitos oriundos de vieses e erros de julgamentos, assinalando inclusive, que tais políticas poderiam dirimir a chance de decisões não serem bem tomadas.

Já Lee e Aaker (2004) demonstraram por meio de experimentos que os frames de ganho são mais persuasivos quando a mensagem é focada na promoção, enquanto os frames de perdas são mais persuasivos quando a mensagem é focada na prevenção.

Estudando o efeito framing, Hoffmann e Fischer (2012) prevêem que em um mundo de dependência de frames, um investidor que é suficientemente avesso ao risco no domínio dos ganhos irá preferir uma posição de compra coberta em relação a uma posição única de ações, independentemente de ambas possuírem o mesmo fluxo de caixa.

Nesse sentido, Versluis et al. (2010) criaram um modelo de precificação de opções que consideram os efeitos propugnados pela Prospect Theory. Os resultados demonstraram que o modelo criado pelos autores significativamente melhoram o desempenho em relação ao clássico modelo de Black-Scholes e que é ao menos equivalente ao modelo de volatilidade estocástica de Heston.

Já Chang (2005) questiona alguns fundamentos basilares da Prospect Theory. Segundo o autor, o fenômeno de atração ao risco no campo das perdas é na realidade o uso inadequado do conceito de custo de oportunidade no campo das perdas.

Visando a testar as teorias e hipóteses dominantes nas finanças comportamentais, Alghalithet al. (2012) tecem algumas críticas à Prospect Theory. Baseando-se em Bovi (2009) e Alghalith (2010), os autores explicam que a teoria fundamentada por Kahneman e Tversky (1979) não sugere qual seria a reação (ou mesmo a interpretação) do mercado para um determinado evento econômico. De acordo com Alghalithet al. (2012), a atitude de risco de uma dada pessoa em uma dada situação depende de outros fatores, tais como a situação econômica de cada indivíduo e como ele a vê ou a interpreta. 
Adicionalmente, os mesmos autores explanam que a Prospect Theory também adota o princípio de que os indivíduos são avessos ou propensos ao risco com base na diminuição ou aumento da utilidade marginal, o que traria limitações a teoria.

No sentido dos resultados da pesquisa de Alghalith et al. (2012), ao utilizar um modelo de portfólio padrão de dados pertencentes à Standard and Poor's 500 (S\&P 500), os autores encontraram evidências de que os indivíduos são pessoas que buscam risco, tanto no campo dos ganhos quanto das perdas, o que acabaria por contradizer a Prospect Theory. Entretanto, é importante relatar que tais achados foram obtidos através da estimação com equações, diferentemente do trabalho feito nessa tese. Nesse sentido, Barberis (2013) explica que desde a consecução da respectiva teoria por Kahneman e Tversky em 1979, os pesquisadores vem apresentando dificuldades em exatamente como aplicar os achados da mesma.

Apesar das dificuldades ressaltadas, Barberis (2013) cita que muitos modelos econômicos vêm incorporando os achados da Prospect Theory, muito embora ainda existam críticas de que os achados empíricos somente se aplicariam sob circunstâncias experimentais. Apesar de relatar esse ponto, o autor deixa bem claro que não compartilha tal visão.

Por sua vez, Cason e Plott (2014) fizeram um simples experimento, em que o valor de um cartão poderia ser trocado por \$2. A medida não produziu as preferências conhecidas pela teoria econômica de preferências, de modo que ela foi mais bem explicada pela teoria dos framings.

Em trabalho de 2015, Bahmanziari e Odom estudaram o efeito framing no cenário de ecommerce. Trabalhando com estudantes de uma universidade matriculados em cursos de contabilidade e administração, os autores concluíram que as evidências fortemente sugeriam que os efeitos de framing influenciavam nas escolhas dos consumidores. Bahmanziari e Odom (2015) também ressaltaram que a garantia interagiam com esses efeitos alterando as escolhas dos indivíduos.

Nesse sentido, Liu et al. (2014) também analisaram as implicações da Prospect Theory em cenário de compras online. Contudo, diferentemente dos anteriores, os autores tiveram como foco em seu estudo o processo de trading financeiro. Buscando fazer um trabalho empírico em grande escala, Liu et al. (2014) analisaram 28,5 milhões de trades feitas por 81.300 
traders de uma comunidade de trading financeiro online por um período de mais de 28 meses. Verificando o comportamento vencedor e perdedor de diferentes traders, os autores encontraram evidências fortes da presença do efeito reflexão, isto é, os investidores se mostravam avesso aos riscos no campo dos ganhos e propensos aos riscos no campo das perdas. Não obstante, Liu et al. (2014) também relataram que foi observado o fenômeno de aversão à perda.

Baseado em Hossain e List (2012), Brooks et al. (2012) sugerem que contratos feitos em termos de perdas (por exemplo, uma dedução é feita por não se atingir uma meta) tendem a guiar os indivíduos para um maior esforço para atingir os objetivos do que se ele for firmado em termos de ganhos (por exemplo, um bônus ser dado por se atingir certa meta). Os autores comentam que isso provavelmente se deve ao fato do bônus ser o status quo na primeira opção.

Neste sentido, Goldsmith e Dhar (2013) colaboram com tal visão. Usando uma amostra de estudantes de graduação e adultos, os autores demonstram que a maneira como um incentivo é dado influencia na motivação na elaboração das tarefas. Os pesquisadores perceberam que as pessoas se sentiam mais motivadas quando o incentivo era dado no sentido de evitar uma perda do que atingir um ganho.

Em trabalho estritamente relacionado ao desenvolvimento dessa tese, Anagol e Gamble (2013) examinaram como a apresentação dos resultados de investimentos afetam os riscos tomados pelos indivíduos. Utilizando uma amostra de 249 participantes em uma simulação de investimentos para aposentadoria, os autores concluíram que os resultados foram consistentes com uma combinação de três aspectos de modelos baseados na Prospect Theory:

(i) Aversão à perda;

(ii) O framing oriundo do resultado de ativos individuais;

(iii) A sensibilidade diminui em relação a ganhos e perdas agregadas.

Baghestanian et al. (2015) estudaram como as interações sociais influenciam nos resultados de mercado. Os autores relatam que informações geradas pelos pares reduzem a "sub diversificação", modificando as atitudes de risco que duram para além do ambiente de mercado. Não obstante, os pesquisadores explanam que o efeito da informação depende de 
seu framing, isto é, destacar o trader de maior ganho aumenta a disposição dos indivíduos de tomarem risco e se expor no mercado.

Por sua vez, Rabin e Weizsacker (2009) testaram as ideias de Tversky e Kahneman (1981) de que analisar decisões de risco separadamente podem conduzir a combinações que são dominadas por outras. Os autores demonstraram que um tomador de decisões que não tem preferências absolutamente constantes de aversão ao risco e que avaliam suas decisões uma por uma, existe um par de decisões binárias onde o tomador de decisão irá escolher uma combinação de escolhas dominadas.

Destacando o poder preditivo da Prospect Theory, Kudryavtsev e Pavlodsky (2012) comentam que a mesma, conjuntamente com o modelo de Expectancy-Valence e suas possíveis combinações, são as melhores para predizer as decisões das pessoas em tarefas de experimentos e descrição.

Por sua vez, Ebert e Wiesen (2014) propõem um método que considera não somente a aversão ao risco, mas seu efeito combinado com a prudência e a temperança. De acordo com os autores, as mesmas se encontram correlacionadas. Entretanto, Ebert e Wiesen (2014) relatam que as compensações suscitadas para a prudência são significativamente maiores do que aquelas observadas à aversão ao risco e à temperança. Os autores comentam que tanto os amantes do risco, quanto os neutros e os conservadores se mostraram prudentes. Logo, isso sugeriria que a prudência pode ser um traço mais universal do que se parece.

Em cenário brasileiro, Decourt et al. (2007) testaram os aspectos propostos pela Prospect Theory no processo de tomada de decisões de investimentos com estudantes de MBA e médicos. No tocante ao efeito framing, os autores relataram que a forma como as informações eram dispostas influenciava tanto como os estudantes de MBA quanto os médicos tomavam suas decisões, o que levanta indícios de que o efeito pode ser observado com profissionais de diferentes campos, sugerindo a amplitude do mesmo.

Testando as ideias de Tversky e Kahneman (1974) em solo brasileiro, Haubert et al. (2012) realizaram pesquisa quantitativa através do uso de questionário com 94 estudantes strictu sensu da Grande Florianópolis. Os autores observaram o que havia sido previsto pela 
Prospect Theory, isto é, os estudantes apresentavam aversão ao risco no campo dos ganhos e propensão a tomar riscos no campo das perdas.

Em trabalho análogo, Haubertet al. (2014) fizeram estudo com 130 estudantes strictu sensu de Lisboa. Os achados foram similares no sentido de que mesmo se tratando de pessoas de localidades geográficas diferentes, ainda assim os estudantes apresentavam aversão ao risco no campo dos ganhos e propensão a tomar riscos no campo das perdas. Como se vislumbra, essa análise comparativa pode sugerir que o efeito framing pode ser observado com pessoas de diferentes países, realçando o caráter intrínseco ao ser humano que ele apresenta.

Por sua vez, Dantas e Macedo (2013) aplicaram outro estudo similar com 215 estudantes do curso de graduação em ciências contábeis de uma instituição de ensino superior da cidade do Rio de Janeiro. Tal como os demais trabalhos citados nessa seção, não houve foco nas notas explicativas e na divulgação dos demonstrativos financeiros propriamente ditos. Novamente analisando sob uma perspectiva mais gerencial de tomada de decisão de investimentos, os autores também concluíram que os indivíduos pesquisados contrariavam princípios da racionalidade econômica, tais como o de invariância, sugerindo que as pessoas se tornavam avessas ao risco no campo dos ganhos e propensos ao risco no campo das perdas. Contudo, Dantas e Macedo (2013) fizeram importantes ressalvas quanto a forma como isso ocorria. Os autores relataram que a experiência profissional e a acadêmica influenciavam no desempenho dos respondentes, de modo que estas ajudavam a "amenizar a ação deste viés nos estudantes da amostra" (p. 63). Adicionalmente, a experiência acadêmica influenciava positivamente na redução do efeito pseudocerteza. Finalmente, Dantas e Macedo (2013) teceram comentários no tocante a indícios de que as mulheres possuíam "maior sensibilidade ao efeito de enquadramento das escolhas" (p.63).

Em trabalho de 2013 com 155 estudantes de pós-graduação lato sensu de cinco Instituições de Ensino Superior do Rio de Janeiro, Barreto et al. também chegaram a mesma conclusão de que as pessoas se tornavam propensas ao risco no campo das perdas, porém eram extremamente avessas ao mesmo quando um ganho já era certo.

Existem vários outros trabalhos publicados em cenário nacional em que houve concordância com tais achados. Silva et al. (2009) fizeram estudo com estudantes de graduação em ciências contábeis e também chegaram a conclusões equivalentes. Seguindo conclusão similar a de 
Dantas e Macedo (2013), os autores notaram que os respondentes do sexo feminino pareciam possuir uma aversão mais acentuada ao risco do que os homens. Entretanto, diferentemente de Dantas e Macedo (2013), os autores realçaram que experiência acadêmica (posição do aluno no curso) não fazia diferença nos achados.

Diferentemente dos demais autores que tiveram suas amostras basicamente composta por estudantes, Yoshinaga e Ramalho (2014) fizeram sua pesquisa com funcionários que trabalham nos segmentos de varejo e alta renda de uma importante instituição financeira brasileira alocada em São Paulo (p. 600). De um total de 21.267 questionários enviados aos respondentes, 2.590 os responderam por completo.

Yoshinaga e Ramalho (2014) chegaram às seguintes conclusões:

a) Os resultados pareceram confirmar a presença do efeito certeza. Segundo o mesmo, um dado indivíduo prefere um ganho certo mesmo que este seja menor um ganho altissimamente provável, o que leva a subestimação da esperança média do ganho;

b) No tocante ao efeito de reflexão, os resultados, de modo geral, não contradisseram o preconizado pela Prospect Theory, que diz que os indivíduos são avessos ao risco no campo dos ganhos e propensos ao risco no campo das perdas;

c) Finalmente, os autores também observaram o efeito isolamento nos resultados. Tal efeito é a análise individual de decisões, sem considerar o efeito conjunto das mesmas, tal como discorrido em seção anterior dessa tese. 


\section{Procedimentos Epistemológicos e Metodológicos}

Este capítulo dessa tese versa sobre os procedimentos metodológicos adotados pela mesma. Para tanto, são discutidos os aspectos epistemológicos e metodológicos adotados, além da aplicação empírica das discussões teóricas do último capítulo.

\subsection{Introdução aos Procedimentos Epistemológicos e Metodológicos}

Essa tese foi desenvolvida sobre o arcabouço epistemológico e metodológico tal como definido por Martins e Theóphilo (2007). Segundo tais autores, o desenvolvimento do conhecimento se dá em quatro polos (Martins e Theóphilo, 2007):

- Polo Epistemológico: exerce uma função de vigilância crítica da pesquisa;

- Polo Teórico: é o que ajuda a definir a construção das hipóteses e dos conceitos subjacente à pesquisa;

- Polo Metodológico: diz respeito de como a realidade será tratada;

- Polo Técnico: cuida dos procedimentos técnicos propriamente ditos, como a coleta dos dados e construção dos experimentos.

Com vistas a organizar como essa tese foi desenvolvida, esta seção se dividirá nos quatro polos, onde serão discutidos os principais problemas atinentes ao desenvolvimento da mesma.

\subsubsection{Polo Epistemológico}

Conforme Martins e Theóphilo (2007) citam, a epistemologia se situa tanto na lógica da descoberta como na lógica da prova. De acordo com os autores, grande parte da lógica da descoberta esteve historicamente definida na busca da relação causal das variáveis.

Para esta tese, foi considerada a visão de Morin (1996) como orientadora do desenvolvimento epistemológico da pesquisa. Este autor se assenta na concepção epistemológica da complexidade. Tal pensador explana que o princípio de explicação da ciência clássica excluía a aleatoriedade para apenas conceber um universo estrita e totalmente determinista. Contudo, hoje em dia, as ciências trabalham cada vez mais com a aleatoriedade, sobretudo para 
compreender tudo aquilo que é evolutivo, e consideram um universo em que se combina o acaso e a necessidade.

Logo, essa tese assume que lida com variáveis aleatórias e que os resultados podem variar na presença de diferentes variáveis de controle e na presença de informações a priori (tal como na estatística bayesiana). Não obstante, é importante mencionar que o uso da concepção epistemológica da complexidade reconhece que nenhum conhecimento é suficientemente simples que possa ser representado meramente por expressões matemáticas, mas que há uma noção de caos associada ao desenvolvimento científico, o que garante que os achados podem divergir na presença de diferentes condições que estão subjacentes ao desenvolvimento do procedimento científico.

Dessa maneira, segundo Morin (1996), surge a necessidade de um princípio de explicação mais rico do que o princípio de simplificação, que o autor denomina de princípio de complexidade. Este, além de se basear na necessidade de distinguir e de analisar, procura estabelecer a comunicação entre aquilo que é distinguido: o objeto e o ambiente, a coisa observada e o seu observador. Se não bastasse isso, ele também se esforça por abrir e desenvolver amplamente o diálogo entre ordem, desordem e organização, para conceber os fenômenos físicos, biológicos e humanos.

\subsubsection{Polo Teórico}

Toda investigação sem teoria é vazia. Assim sendo, a teoria molda a observação, de modo que toda descrição do que está sendo observado possui uma teoria como pré-requisito, mesmo que esta seja o próprio senso comum.

Esta tese possui a teoria do prospecto (Prospect Theory) de Kahneman e Tversky como principal arcabouço teórico subjacente ao desenvolvimento da mesma. Isso não implica, contudo, que teorias conflitantes não possam explicar melhor a realidade.

Dessa maneira, os resultados podem convergir a teorias conflitantes, como os axiomas de preferência que sustentam a regra de utilidade esperada oriunda de princípios simples de escolhas racionais. Esta visão de confrontar empiricamente teorias com o uso de hipóteses é o 
que embasa a concepção popperiana de ciência, a ser melhor detalhada na seção de polo metodológico.

Adicionalmente, tal concepção também está de acordo com Kerlinger (1991). Na visão desse autor, ao se tentar resolver um problema, procuram-se soluções alternativas, meios diferentes de se chegar ao núcleo do problema.

Não obstante, Kerlinger (1991) realça que as próprias hipóteses são deduzidas da teoria e que devem ser testáveis ou conter, no mínimo, implicações para teste.

\subsubsection{Polo Metodológico}

No tocante ao desenvolvimento metodológico, essa tese adota o que se chama de método científico hipotético-dedutivo, que é uma adaptação das ideias de Popper. É importante mencionar, contudo, que não se deve interpretar o método hipotético-dedutivo de forma rígida, imutável. Trata-se de uma metodologia orientadora do proceder científico. Abaixo, segue ilustração desse método, conforme Köche (1997) fez: 


\section{MÉTODO CIENTÍFICO HIPOTÉTICO-DEDUTIVO}

Conhecimento prévio $\longleftrightarrow$ observação $\longleftrightarrow$ fatos, fenômenos

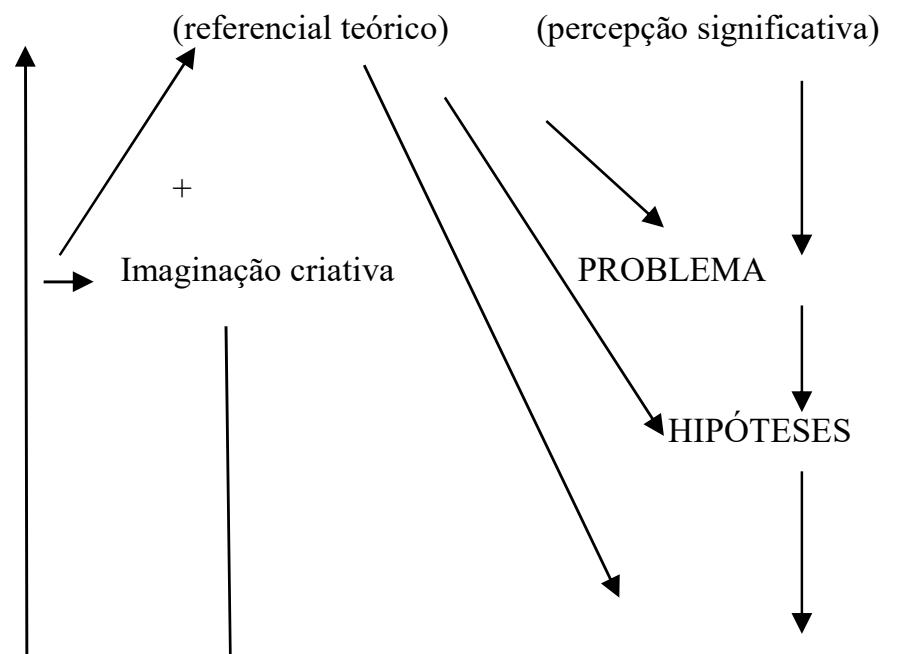

Testagem das hipóteses

(Observação descritiva ou experimentação)

Intersubjetividade e falseabilidade

Interpretação e avaliação da testagem das hipóteses

Rejeição das hipóteses

Não rejeição das hipóteses (corroboração)
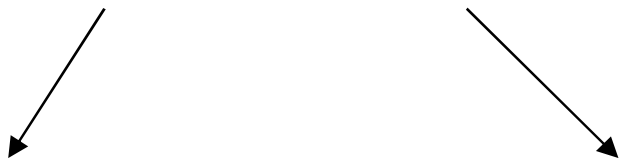

$\mathrm{DE}$

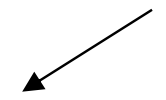

Nova Teoria

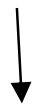

Novo Problema

Figura 3 - Método Científico Hipotético-Dedutivo

Fonte: Köche (1997, p.70)

Tal método, como se observa, parte de um problema, uma situação que mereça investigação. Nessa tese, o problema investigado é: As heurísticas e os vieses influenciam o processo decisório dos indivíduos quando confrontados com os dados oriundos das demonstrações financeiras e contábeis publicadas pelas empresas? 
Com base nesse problema, cria-se uma hipótese, isto é, uma conjectura que busca responder de antemão o que se espera que ocorra, com base na teoria que funciona de arcabouço para sustentar o trabalho (Kerlinger, 1991).

Nesta tese, foi adotada a seguinte conjectura: As heurísticas e os vieses influenciam de modo relevante o processo decisório dos indivíduos quando confrontados com os dados oriundos das demonstrações financeiras e contábeis publicadas pelas empresas.

Como Köche (1997) explana, na visão de Popper, a conjectura é submetida aos testes empíricos mais severos, com vistas a falseá-la, o que explica tal metodologia ser conhecida como o falibalismo popperiano. Estes testes envolveriam, inclusive, a comparação com hipóteses concorrentes. A não rejeição da hipótese poderia levar a novas teorias que colaborariam com o surgimento de novos problemas.

Nesse sentido, Newton-Smith (1997) comenta que na visão de Popper, esse quadro não se baseava numa mera generalização, como visto no método indutivo-confirmável. Na verdade, se baseava num argumento filosófico a priori de Hume. Este pensador se contentava inteiramente com argumentos dedutivos, de modo que qualquer argumento no qual as premissas implicassem a conclusão era aceitável para ele.

De acordo com Newton-Smith (1997), Popper levava Hume a sério, implicando que ele rejeitava todo argumento não-dedutivo, incluindo a estratégia de passar a acreditar na verdade ou na verdade provável parcial de hipóteses, tomando por referência o seu poder explicativo (chamada de inferência para a melhor explicação, um tipo particular de indução).

Newton-Smith (1997) passa a chamar esse aspecto antiindutivo da teoria da ciência de Popper de seu Grande Experimento. O autor explica que para Hume, não há escolha, de modo que temos de agir indutivamente, sendo que isto seria parte de nossa natureza. Por sua vez, para Popper, os cientistas não deveriam utilizar a indução e tampouco tolerá-la.

Newton-Smith (1997) realça novamente que Popper propunha um objetivo mais modesto para a ciência: obter teorias de verossimilhança cada vez maior, isto é, teorias que contem mais verdades e não falsidades do que suas anteriores. O autor comenta que há um argumento que 
corrobora com essa afirmação que ele e outros filósofos da ciência, outrora, deram força. Tal argumento se sustenta no fato de que a melhor explicação de seu sucesso preditivo reside no pressuposto de que estamos acertando mais no nível teórico, pela descoberta das estruturas fundamentais no mundo.

Entretanto, Newton-Smith (1997) explica que este argumento é um grande argumento indutivo, de modo que é um exemplo de inferência para a melhor explicação aplicada ao fenômeno do progresso em direção ao objetivo manifesto da ciência. Nesse âmbito, o autor explica que Popper viu-se num dilema devastador: ou se aceitava esse argumento indutivo para justificar a tese do progresso, ou não se via a ciência como um paradigma de racionalidade.

Essa tese compartilha a ideia de Newton-Smith de que não há a criação de ciência sem o método indutivo, assim como não há desenvolvimento científico sem o raciocínio lógicodedutivo. Apesar de Popper rejeitar a indução (o que implica no método hipotético dedutivo), não há como abandoná-la. Logo, o polo metodológico orientador do desenvolvimento dessa tese é a visão popperiana, mas não no sentido puro de rejeição da indução, mas sim de uma cooperação do raciocínio indutivo e dedutivo e de testes de hipóteses, com vistas a obter teorias cada vez mais verossímeis.

Isso ocorre, pois o próprio emprego de questionários já traz em seu seio um cunho indutivo. Se as ideias de Popper fossem aplicadas de um ponto de vista ipsis literis, isso só levaria o trabalho a um paradoxo lógico, onde se rejeita a indução, mas a utiliza como motor explicativo do progresso da ciência, tal como ocorreu com o próprio Popper.

\subsubsection{Polo Técnico}

Segundo Martins e Theóphilo (2007), “o questionário é um importante e popular instrumento de coleta de dados para uma pesquisa social", isto é, trata-se de um conjunto ordenado e consistente de perguntas a respeito do que se deseja medir.

Nesta tese, foram submetidos 369 questionários a alunos dos cursos de graduação em Ciências Contábeis, Ciências Atuariais e Ciências Econômicas da Faculdade de Economia, Administração e Contabilidade da Universidade de São Paulo. Não obstante, também foram 
submetidos 55 questionários para um grupo de analistas de mercado de uma grande e importante instituição financeira do mercado nacional. Todos os questionários foram submetidos durante o ano de 2016.

De modo geral, pode-se dizer que o questionário era composto por duas grandes seções. $\mathrm{Na}$ primeira delas, buscava-se traçar o perfil social e acadêmico dos respondentes. Vale a pena relatar que esta seção possui algumas diferenças nas versões dos questionários submetidos aos estudantes e aos analistas que serão abordadas a seguir.

Por sua vez, a segunda abordava o perfil de decisão do respondente, isto é, a mesma procurava observar como os indivíduos efetivamente se comportavam em situações de incerteza na presença de informações contábeis. $\mathrm{O}$ objetivo principal era verificar se os sujeitos decidiam tal como o preconizado pela Prospect Theory de Kahneman e Tversky.

Com isso, pode-se dizer que ao passo que a segunda seção busca identificar como os sujeitos decidem na presença de situações que conduzem ao uso de heurísticas que propiciam vieses, a primeira seção levanta variáveis que possam explicar a propensão para responder de acordo com os vieses acima relatados.

Conforme o apêndice 1 ilustra, as questões eram majoritariamente dicotômicas, com exceção de alguns itens do perfil social.

A seguir, são descritas as duas seções do questionário.

\subsubsection{Análise Crítica do Questionário - Perfil Social e Acadêmico}

O perfil social e acadêmico variava se o questionário havia sido submetido aos alunos ou aos analistas de mercado. A seguir, encontra-se tabela sinótica que descreve as informações colhidas junto aos alunos: 


\begin{tabular}{|c|}
\hline Informação Colhida \\
\hline Gênero \\
\hline Idade \\
\hline Estado civil \\
\hline Quantos filhos o respondente possui \\
\hline Curso que o respondente está fazendo \\
\hline Mês de ingresso no curso \\
\hline Mês de previsão do término \\
\hline Se o respondente estagia ou trabalha (se sim, há quanto tempo?) \\
\hline Se o respondente participa ou já participou de um projeto de \\
iniciação científica (se sim, quando?) \\
\hline Se o respondente possui outra formação (Se sim, qual?) \\
\hline
\end{tabular}

Quadro 1 - Informações complementares colhidas junto aos alunos da FEA/USP

Por sua vez, as informações colhidas junto aos analistas se encontram discriminadas abaixo:

\begin{tabular}{|c|}
\hline Informação Colhida \\
\hline Gênero \\
\hline Idade \\
\hline Estado civil \\
\hline Quantos filhos o respondente possui \\
\hline O curso em que o respondente se formou \\
\hline Se o respondente já investiu em renda variável \\
\hline Se o respondente já investiu em renda fixa \\
\hline Se o respondente usa os relatórios financeiros e contábeis \\
divulgados pelas empresas para embasar seu processo decisório \\
\hline
\end{tabular}

Quadro 2 - Informações complementares colhidas junto aos analistas da IF

Essas questões foram submetidas com vistas a levantar o perfil geral de cada indivíduo com vistas a identificar relações com o perfil de decisão do respondente propriamente dito.

\subsubsection{2. $\quad$ Análise Crítica do Questionário - Perfil de Decisão}

A seguir, é feita uma análise crítica do perfil de decisão submetido aos estudantes da Faculdade de Economia, Administração e Contabilidade da Universidade de São Paulo, assim como aos analistas de mercado de uma importante e grande instituição financeira brasileira. Conforme pode ser evidenciado nos apêndices, o perfil de decisão é composto de 8 questões, sendo que cada uma buscou capturar se haviam indícios da presença de um dado viés ou heurística no processo de tomada de decisão de um agente econômico, quando submetido em uma situação de incerteza que envolvia o uso de conceitos contábeis, majoritariamente 
oriundos de notas explicativas de demonstrações financeiras. Serão detalhadas as hipóteses subjacentes a cada questão à luz da teoria que embasa essa tese.

Tendo em vista as discussões de framing feitas a priori, foram criadas duas versões para algumas questões que envolviam pequenas diferenças, de modo que existiam duas versões do questionário aplicado. Os indivíduos não estavam cientes desse fato, tendo em vista que eles o responderam individualmente e os dois questionários eram parecidos em termos de aparência. Quando da discussão dessas questões em particular, serão feitas menções especiais das duas versões.

Vale a pena ressaltar que o questionário também possuía uma parte que visava a levantar o perfil social do respondente. Tal parte será melhor abordada quando da análise estatística dos padrões observados.

\subsection{Questão 1}

O referencial teórico que consubstanciou a elaboração da questão 1 pode ser encontrado no artigo seminal de Kahneman e Tversky de 1984, já discorrido anteriormente, na seção de revisão de literatura.

Seu objetivo era verificar se os respondentes do questionário estavam suscetíveis a sofrerem o efeito certeza, reflexão e isolamento em um ambiente de incerteza envolvendo o uso de informações contábeis.

Kahneman e Tversky (1984) explicam que toda função de valor hipotética é definida em termos de ganhos e perdas e não em termos de riqueza total. Não obstante, a mesma é côncava no domínio dos ganhos e convexa no domínio das perdas, sendo que ela é mais abrupta no domínio das perdas.

Como se nota, a questão 1 é dividida em duas decisões. A decisão 1 buscou verificar se o indivíduo era avesso ao risco no campo dos ganhos, isto é, se o mesmo preferia realizar um lucro certo ao invés de apostar mais. 
No papel de um analista de mercado de capitais, o respondente era colocado numa situação onde ele havia recomendado a compra de 100 ações ordinárias de uma seguradora que trabalha com grandes riscos a um preço de $\mathrm{R} \$ 35,00$ em 31 de Dezembro de 2014. Após a publicação dos demonstrativos financeiros em Abril de 2015, esta seguradora havia apresentado um lucro o que tinha feito com que o preço da ação disparasse para $\mathrm{R} \$ 45,00$. Contudo, conjuntamente com a divulgação do lucro, havia uma nota explicativa que versava sobre um passivo contingente da entidade (uma ação civil) que poderia comprometer cerca de $40 \%$ de seu patrimônio líquido. Contudo, como o mesmo não era provável, sua probabilidade de não ocorrência era de apenas $10 \%$.

Posteriormente, era apresentada uma variável aleatória extremamente simples ao sujeito que estava respondendo o questionário. Se o passivo contingente se materializasse nesse ano, o preço da ação cairia para $\mathrm{R} \$ 30,00$, ao passo que em caso contrário, existiam expectativas de que o preço da ação subiria para $\mathrm{R} \$ 55,00$. Assim sendo, indagava-se se o respondente recomendaria a venda da ação agora ou no final do ano.

Em termos matemáticos, pode-se dizer que o problema era a seguinte questão: valeria a pena não vender a ação ou o lucro certo de R $\$ 10,00$ por ação já deveria ser realizado nesse momento?

Definindo X como o lucro com uma ação no final do ano, pode-se vislumbrar que a mesma é uma variável aleatória com a seguinte função massa de probabilidade:

$P(X=R \$ 55,00-R \$ 35,00=R \$ 20,00)=0,90$
$P(X=R \$ 30,00-R \$ 35,00=-R \$ 5,00)=0,10$

Assim sendo, calculando a esperança da mesma:

$E(X)=R \$ 20,00 \times 0,90-R \$ 5,00 \times 0,10=R \$ 17,50$

Considerando uma taxa de juros de 14\% a.a. (taxa média de juros no Brasil) e calculando o valor presente aproximado (desconto de $3 / 4$ de um ano para colocar o valor da esperança no mesmo momento do ganho certo), chega-se ao seguinte resultado: 
$V P(E(X))=\frac{R \$ 17,50}{(1+0,14)^{3 / 4}} \cong R \$ 15,86$

Como se nota, a esperança da aposta é maior do que o ganho certo de $\mathrm{R} \$ 10,00$, o que poderia sugerir que um indivíduo racional, sem necessidade de liquidez imediata, poderia preferir apostar.

Entretanto, como Kahneman e Tversky (1984) explanam, os indivíduos são conservadores no campo dos ganhos, o que leva ao surgimento do efeito certeza. Assim sendo, esta pesquisa adota a hipótese de que a proporção de indivíduos que optaram por recomendar a venda das ações agora e realizar o lucro de $\mathrm{R} \$ 10,00$ por ação é maior estatisticamente do que os indivíduos que prefeririam recomendar a venda da ação no final do ano. Esta será definida como a hipótese 1 a ser testada nessa tese.

É mister relatar que assim como em todas as questões a posteriori, o perfil social será considerado para verificar se as respostas variam na presença de variáveis de controle.

Por sua vez, a decisão 2 tentava identificar se os sujeitos eram propensos a tomarem risco no campo das perdas, tal como preconizado pelo efeito reflexão de Kahneman e Tversky (1984). $\mathrm{Na}$ visão dos autores, a função hipotética de valor para um dado sujeito é convexa no campo das perdas. Em termos matemáticos, isso implica em dizer que na presença de uma perda certa, um sujeito tende a estar disposto em apostar, mesmo que a esperança matemática da perda seja ainda maior.

De modo estritamente análogo à decisão 1 , o questionário ainda punha o respondente no papel de um analista de mercado de capitais que tinha recomendado a compra de 100 ações ordinárias de uma dada empresa no dia 31 de Dezembro de 2014 a um preço de $\mathrm{R} \$ 20,00$ por ação. Contudo, após a divulgação dos demonstrativos financeiros em Abril de 2015 e um prejuízo oriundo de uma desvalorização de ativos financeiros mantidos a valor justo, o preço da ação tinha caído para $\mathrm{R} \$ 10,00$.

Após essa descrição, era apresentada a situação de incerteza na qual envolvia a decisão. Os ativos mantidos a valor justo tinham $10 \%$ de probabilidade de sofrerem uma grande 
valorização, o que elevaria o preço da ação a $R \$ 25,00$. Por sua vez, se um cenário pessimista se consubstanciasse, a ação passaria a valer $\mathrm{R} \$ 2,00$.

Novamente, definindo Y como o lucro com uma ação no final do ano, pode-se perceber que a mesma é uma variável aleatória com a seguinte função massa de probabilidade:

$P(Y=R \$ 2,00-R \$ 20,00=-R \$ 18,00)=0,90$

$P(Y=R \$ 25,00-R \$ 20,00=R \$ 5,00)=0,10$

Com isso, calculando a esperança de $\mathrm{Y}$ :

$E(Y)=-R \$ 18,00 \times 0,90+R \$ 5,00 \times 0,10=-R \$ 15,70$

Assumindo novamente que o indivíduo seja racional e que ele pudesse arcar com o prejuízo da operação no momento da divulgação das demonstrações contábeis, ele optaria por recomendar a venda da ação imediatamente, pois a perda certa de $\mathrm{R} \$ 10,00$ é menor do que a perda esperada de $\mathrm{R} \$ 15,70$, sem considerar o efeito de taxa de juros.

Considerando uma taxa de juros de 14\% a.a. e calculando o valor presente aproximado (desconto de $3 / 4$ de um ano para colocar o valor da esperança no mesmo momento da perda certa), chega-se ao seguinte resultado:

$V P(E(Y))=\frac{-R \$ 15,70}{(1+0,14)^{3 / 4}} \cong-R \$ 14,23$

Isso implica dizer que mesmo em um cenário de uma alta taxa de juros, a esperança da perda da variável aleatória seria maior do que a perda certa de $\mathrm{R} \$ 10,00$.

Contudo, segundo a Prospect Theory de Kahneman e Tversky (1984), os indivíduos desejam o risco no campo das perdas. Logo, se isso realmente se observar, é de se esperar que a proporção de indivíduos que prefiram recomendar a manutenção das ações até o final do ano seja estatisticamente maior do que àqueles que prefiram recomendar a venda imediata. Esta é a hipótese 2 a ser testada nessa tese. 
É interessante notar que as duas decisões faziam parte de uma mesma questão. Adicionalmente, o questionário deixava claro que se tratavam de problemas concomitantes que o respondente estava passando como analista de mercado de capitais e que envolviam o mesmo cliente. Logo, as decisões não deveriam ser avaliadas de modo isolado pelos indivíduos que responderam o questionário. Dessa maneira, a avaliação conjunta das questões revela se o respondente esteve sob o efeito isolamento, isto é, cada decisão foi tomada de modo individual, sem considerar o efeito conjunto (Kahneman e Tversky, 1984).

Assim sendo, o objetivo agora é estimar as possíveis funções massa de probabilidade da variável aleatória $\mathrm{X}+\mathrm{Y}$ (variáveis discutidas anteriormente). Serão abordados os quatro cenários possíveis e as respectivas esperanças dessa variável aleatória:

\section{Cenário 1}

Neste cenário, o respondente optou por recomendar a venda de ambas as ações no momento de divulgação dos demonstrativos contábeis.

Assim sendo, o mesmo ganharia $\mathrm{R} \$ 10,00$ por ação da primeira decisão e perderia $\mathrm{R} \$ 10,00$ com cada ação da segunda empresa. Como seu cliente tinha investido em 100 ações de cada empresa, ele teria um resultado certo de $\mathrm{R} \$ 0,00$ por ação.

\section{Cenário 2}

Neste cenário, o indivíduo resolveu apostar em ambos os cenários, recomendando que ambas as ações fossem vendidas no final do ano. Assumindo que o preço de ambas as ações seja independente, a função massa de probabilidades de $\mathrm{X}+\mathrm{Y}$ seria assim definida:

$$
\begin{gathered}
P(X+Y=R \$ 55,00-R \$ 35,00+R \$ 2,00-R \$ 20,00=R \$ 2,00)=0,9 \times 0,9=0,81 \\
P(X+Y=R \$ 55,00-R \$ 35,00+R \$ 25,00-R \$ 20,00=R \$ 25,00)=0,9 \times 0,1=0,09 \\
P(X+Y=R \$ 30,00-R \$ 35,00+R \$ 2,00-R \$ 20,00=-R \$ 23,00)=0,9 \times 0,1=0,09
\end{gathered}
$$


$(15) P(X+Y=R \$ 30,00-R \$ 35,00+R \$ 25,00-R \$ 20,00=R \$ 0,00)=0,1 \times 0,1=$ 0,01

Dessa maneira, calculando:

$E(X+Y)=R \$ 2,00 \times 0,81+R \$ 25,00 \times 0,09-R \$ 23,00 \times 0,09+R \$ 0,00 \times 0,01=$ $R \$ 1,80$

Novamente, considerando uma taxa de juros de $14 \%$ a.a. e calculando o valor presente aproximado (desconto de $3 / 4$ de um ano), chega-se ao seguinte resultado:

$$
V P(E(X+Y))=\frac{R \$ 1,80}{(1+0,14)^{3 / 4}} \cong R \$ 1,63
$$

\section{Cenário 3}

No terceiro cenário, o respondente opta por realizar o lucro no momento da divulgação das demonstrações contábeis da primeira ação, mas resolver apostar com a segunda, recomendando sua venda somente no final do ano. Nessa situação, a distribuição de probabilidades de $\mathrm{X}+\mathrm{Y}$ fica assim definida (sem considerar o valor do dinheiro no tempo):

$P(X+Y=R \$ 10,00+R \$ 2,00-R \$ 20,00=-R \$ 8,00)=0,90$

$P(X+Y=R \$ 10,00+R \$ 25,00-R \$ 20,00=R \$ 15,00)=0,10$

Dessa maneira:

$E(X+Y)=R \$ 10,00+E(Y)=R \$ 10,00-R \$ 15,70=-R \$ 5,70$

Adotando uma taxa de juros de 14\% a.a. e calculando o valor presente aproximado (desconto de $3 / 4$ de um ano), tem-se que:

$V P(E(X+Y))=R \$ 10,00-R \$ 14,23=-R \$ 4,23$ 


\section{Cenário 4}

Por fim, o último cenário assume que o respondente opta por realizar o lucro no momento da divulgação das demonstrações contábeis da segunda ação, mas resolve apostar com a primeira, recomendando sua venda somente no final do ano. Com isso, a função distribuição de probabilidades de $\mathrm{X}+\mathrm{Y}$ fica assim definida sem considerar o valor do dinheiro no tempo:

$P(X+Y=R \$ 55,00-R \$ 35,00-R \$ 10,00=R \$ 10,00)=0,90$

$P(X+Y=R \$ 30,00-R \$ 35,00-R \$ 10,00=-R \$ 15,00)=0,10$

Com isso:

$E(X+Y)=E(X)-R \$ 10,00=R \$ 17,50-R \$ 10,00=R \$ 7,50$

Adotando uma taxa de juros de 14\% a.a. e calculando o valor presente aproximado (desconto de $3 / 4$ de um ano), tem-se que:

$V P(E(X+Y))=R \$ 15,86-R \$ 10,00=R \$ 5,86$

Após a análise dos quatro cenários, considerando que o indivíduo não possui problemas de liquidez e que ele possa arcar com qualquer prejuízo, a decisão racional a se adotar seria a de recomendar a venda da primeira ação somente no final do ano, mas recomendar a venda imediata da segunda ação.

Se os indivíduos analisaram o par de decisões de modo individual, há de se supor, considerando a Prospect Theory de Kahneman e Tversky (1984), de que eles foram influenciados pelo efeito certeza e pelo efeito reflexão. Logo, seu par de decisão seria o oposto do preconizado acima, isto é, ele recomendaria a venda imediata da primeira ação e somente recomendaria a venda da segunda ação no final do ano. A hipótese 3 dessa tese busca identificar justamente esse comportamento, isto é, qualquer par de decisões que não seja o discorrido no cenário 4 se configura indícios de que os respondentes estiveram sob o efeito isolamento quando do preenchimento do questionário. 


\subsection{Questão 2}

Diferentemente da questão 1 , a questão 2 possuía duas versões que tinham conteúdo informacional idêntico, mas que estavam ancoradas sob prismas diferentes (Tversky e Kahneman, 1974).

Como Tversky e Kahneman explanam (1974), as pessoas fazem estimativas com base em um valor inicial que vai sendo ajustado para produzir a decisão final. Conhecida como a heurística da ancoragem, essa questão buscou verificar se existiam efeitos de formulação, isto é, se a forma como o problema era apresentado influenciava a forma como os seres humanos tomam suas decisões (Kahneman e Tversky, 1984).

A questão abordava a situação hipotética de uma empresa no setor de varejo que possuía um patrimônio líquido de R\$ 1000,00 (em milhões de reais) no dia 31 de dezembro de 2015. Concomitantemente com essa informação, era apresentada ao respondente uma nota explicativa que versava sobre as estimativas de risco de mercado da referida empresa, que tinha calculado um VaR (Value at Risk) para o próximo ano.

Neste momento, as duas versões do questionário se faziam presentes. A primeira era ancorada na não perda, dizendo que o nível de confiança adotado era de $95 \%$ e que o VaR de toda a empresa era R\$100 (em milhões de reais). Na segunda, tanto o VaR quanto o nível de confiança adotado era estritamente o mesmo. Porém, dizia-se que o VaR havia sido estimado com um nível de significância de 5\%, sendo portanto ancorado na perda.

Então, indagava-se ao respondente se ele recomendaria a compra da ação dessa empresa. Conforme se vislumbra, não há mudança alguma no fato a ser divulgado e em ambos, o VaR da empresa para o próximo ano representa $10 \%$ de seu patrimônio líquido. Entretanto, a formulação do problema variava a ancoragem em que o indivíduo utilizaria para decidir (não perda ou perda).

Tais questões, como já dito anteriormente, podem ser vistas nos apêndices dessa tese. 
Dessa maneira, a hipótese 4 a ser testada nessa tese é a de que a proporção de indivíduos que recomendam a compra da ação é estatisticamente maior quando a nota explicativa está ancorada na não perda.

\subsection{Questão 3}

De modo análogo à última questão, a questão 3 também buscava capturar se o efeito de formulação influenciava o processo decisório em um ambiente que usava informações contábeis. Logo, a mesma também possuía duas versões, de modo que alguns indivíduos responderam a primeira versão e outros responderam a segunda versão.

Nela, era apresentada uma versão resumida de um balanço patrimonial consolidado de uma empresa em 31 de Dezembro de 2015. O balanço apresentado era absolutamente o mesmo em ambas as versões.

Então, o problema pedia para o respondente se portar como um responsável por aprovar um crédito que a empresa estava tentando tomar com o banco em que você trabalhava. Em ambas as versões, era dito de que o empréstimo seria quitado em 12 parcelas no próximo ano. Contudo, o valor do empréstimo era apresentado de maneira diferente. Na primeira versão, falava-se que a referida empresa buscava um empréstimo de $\mathrm{R} \$ 4.500$ (em milhões de reais), ao passo de que na outra, a empresa buscava um empréstimo que equivalia a 5 vezes o patrimônio líquido. Como o patrimônio líquido observado no balanço era de R\$ 900 (em milhões de reais), pode-se facilmente notar de que se tratava exatamente de um empréstimo no mesmo valor.

Com isso, a hipótese 5 dessa tese também busca verificar como a heurística da ancoragem influencia (Tversky e Kahneman, 1974) as decisões tomadas quando confrontadas em diferentes cenários de formulação de situações de incerteza (Kahneman e Tversky, 1984).

Logo, será testado se a proporção de indivíduos que aceitam o empréstimo é estatisticamente maior quando o valor do empréstimo foi apresentado em termos brutos ao invés de alavancagem do patrimônio líquido. 
Vale a pena fazer uma única observação. Antes de contraído o empréstimo, a liquidez corrente da empresa para o ano de 2015 era de:

$L C=\frac{5.500}{4.500} \cong 1,22$

Se tomado o empréstimo, como o mesmo seria quitado em até 12 meses, por aproximação, podemos estimar o efeito marginal do empréstimo na liquidez corrente:

$L C=\frac{5.500}{4.500+4.500}=\frac{5.500}{9.000} \cong 0,61$

O que demonstra que ceteris paribus, há indícios de que a empresa teria problemas para honrar essa despesa. Assim sendo, é de se imaginar de que para indivíduos formandos ou formados na área de negócios ou com experiência como analistas de uma instituição financeira não recomendem o empréstimo, independentemente de como o problema foi apresentado. Para todas as questões, serão traçados como o perfil social influencia na forma como os indivíduos tomam suas decisões.

\subsection{Questão 4}

A questão 4 teve como objetivo verificar se os respondentes sofriam os efeitos da correlação ilusória ou se tinham problemas em identificar o sentido estatístico por detrás da correlação. De acordo com Tversky e Kahneman (1974), a frequência em que dois eventos ocorrem concomitantemente pode fazer com que os indivíduos superestimem a ligação associativa entre os mesmos.

$\mathrm{Na}$ questão propriamente dita, era apresentada uma demonstração dos resultados de um banco para o período que compreendia o intervalo entre 1 de Janeiro de 2015 e 31 de Janeiro de 2015. Também era mencionado que essa instituição financeira havia apresentado um lucro sem precedentes na história. Nele, o indivíduo via a descrição dos resultados, o que incluía um resultado de participação sobre o lucro líquido de uma seguradora no valor de R\$ 4.000 (em milhões de reais). Como o lucro líquido apresentado era de R \$ 6.270 (em milhões de reais), verifica-se que ele havia contribuído de maneira substancial ao resultado do período. 
Diante desse cenário, questionava-se se o respondente, no papel de um analista de uma corretora, recomendaria também a compra de ações dessa seguradora para um cliente que já havia comprado as ações do banco, como forma de garantir um lucro no resultado com ações no próximo período.

Obviamente, pode haver uma correlação positiva entre as duas empresas, na medida em que ambas podem ser coligadas ou mesmo haver uma controladora e uma controlada. Entretanto, se os indivíduos superestimarem a correlação das duas, eles podem chegar a uma correlação ilusória. Não obstante, o cliente queria comprar ações para garantir um lucro no próximo período (uma forma de hedge). Assim, ceteris paribus, sob o paradigma da racionalidade, mesmo que ambas apresentem uma alta correlação positiva, não faria sentido recomendar a compra das ações da seguradora como maneira de garantir o lucro do próximo período.

Não obstante, Tversky e Kahneman (1974) também comentam como se materializa a ilusão da validade. Nesse sentido, os autores explicam que a teoria estatística da correlação assegura que uma previsão pode ser feita de forma mais adequada quando as variáveis são independentes entre si. Entretanto, padrões de repetição tendem a fazer com que as pessoas se sintam mais confiantes de suas previsões.

Logo, a hipótese 6 dessa tese é a de que se ocorre o efeito da correlação ilusória e da ilusão de sua validade, tal como preconizado por Tversky e Kahneman (1974), a proporção de indivíduos que recomendaram a compra da ação da seguradora é estatisticamente maior do que aqueles que não recomendaram.

\subsection{Questão 5}

A questão 5 apresentava um cenário hipotético em que uma grande empresa mineradora havia se envolvido em um grave caso de corrupção há 2 anos. Após terem sido tomadas as medidas necessárias e seus demonstrativos contábeis republicados, era apresentado ao respondente um trecho da nota explicativa que versava sobre os riscos operacionais.

Nela, era dito que de acordo com as boas práticas de governança e gerenciamento de riscos, a respectiva mineradora possui estrutura para que tais riscos sejam identificados, mensurados, avaliados e reportados. 
Após essa etapa, indagava-se ao indivíduo se ele compraria uma ação dessa empresa. De acordo com a heurística da disponibilidade, tal como descrita por Tversky e Kahneman (1974), muitas vezes as pessoas recorrem à facilidade com que os fatos ou ocorrências podem ser trazidos à mente para decidirem em situações de incerteza. Nesse âmbito, a facilidade de recuperar eventos pertencentes a uma determinada classe estaria intimamente associada aos vieses devido à recuperabilidade das ocorrências.

Com isso, a hipótese 7 dessa tese pode ser assim exprimida: assumindo que a heurística da disponibilidade é utilizada pelos respondentes em seu processo decisório, pode-se supor que a proporção de indivíduos que não comprariam a ação dessa empresa seria estatisticamente maior em relação aos que comprariam (em virtude da maioria dos respondentes associar a empresa à imagem de corrupção).

Uma consequência importante dessa hipótese é que mesmo na divulgação de informações em notas explicativas, a heurística da disponibilidade pode se manifestar de modo tão intenso que os indivíduos dariam menor importância a ela.

\subsection{Questão 6}

De modo análogo às questões 2 e 3, a questão 6 também possuía duas versões. Em ambas, o respondente se via numa situação em que ele tinha comprado 2 ações de uma dada empresa ao preço de $\mathrm{R} \$ 5,00$ cada uma, sendo que o preço da mesma tinha caído para $\mathrm{R} \$ 4,00$ após a divulgação das demonstrações contábeis do último período. Contudo, a razão da queda do preço da ação variava de acordo com a versão da questão. Em uma delas, se devia a um lucro abaixo do esperado pelo mercado, ao passo que na segunda, isso ocorria em virtude de um prejuízo apresentado devido à situação econômica ruim em que o país vem passando. Perguntava-se, então, se o sujeito ainda compraria outra ação da empresa.

Como se verifica, havia uma mudança de sentido do cenário, de modo que o significado dos cenários não era o mesmo. Entretanto, essa questão objetiva capturar se o termo "lucro" ancorava os respondentes de um modo diferente (Tversky e Kahneman, 1974). 
Se o termo lucro efetivamente influencia no processo decisório dos indivíduos, é de se supor que a proporção de indivíduos que responderam que comprariam outra ação dessa empresa seja estatisticamente superior aos do que comprariam com a empresa apresentando prejuízo. Para deixar a hipótese 8 (acima descrita)mais robusta, o texto foi escrito de modo que o prejuízo não se devia necessariamente a uma má gerência da administração, mas a uma situação econômica ruim em que todo o país vinha passando. Por sua vez, na outra versão, não se falava nada sobre a situação econômica ruim do país, mas a um lucro abaixo do esperado, o que poderia levar o respondente a inferir que o resultado ocorria devido majoritariamente às decisões tomadas pela companhia.

Assim sendo, se a hipótese 8 não for refutada, isso implica em dizer que a maioria dos sujeitos se predispõe a comprar uma ação de uma empresa que apresentou lucro, mas que não se deveu a uma boa gerência, ao invés de comprar uma ação que gerou prejuízo por razões que fugiam majoritariamente de seu controle. Seria análogo a preferir algo ineficiente simplesmente porque ele apresentou lucro.

\subsection{Questão 7}

A questão 7 apresentava um cenário onde um dado banco havia constituído uma estimativa de perdas para créditos de liquidação duvidosa no valor de $\mathrm{R} \$ 1000,00$ (em milhões de reais). Era salientado, então, que após a análise de nota explicativa, todos esses créditos iriam vencer no próximo exercício societário. Não obstante, elas se deviam a 100 clientes independentes entre si com iguais probabilidades de cada um deles efetivamente virem a inadimplir.

Após essa breve descrição, a questão colocava o respondente no papel de um analista que trabalhava na área de crédito do respectivo banco. Então, era comentado que após estudos internos realizados, o banco havia proposto renegociar as dívidas dos clientes. Adicionalmente, comentava-se que estudos anteriores revelavam que $60 \%$ dos clientes aceitavam renegociar suas dívidas. Assim sendo, suponha-se que o Banco já havia ligado para 10 clientes e que somente um dos clientes não havia aceitado renegociar a dívida. Era dito, então, que o $11^{\circ}$ cliente a receber a ligação era do mesmo setor e que vinha passando por situação financeira análoga ao cliente que não havia aceitado renegociar a dívida. Com isso, indagava-se ao indivíduo se na opinião do mesmo, o $11^{\circ}$ cliente aceitaria ou não a renegociação da dívida. 
Partindo-se da questão relatada no último parágrafo, podem-se definir os seguintes conjuntos:

A: Total de clientes que aceitam renegociar as dívidas;

B: Total de clientes (no universo dos 10 que já haviam recebido a ligação) que aceitam renegociar as dívidas.

Seja, então, a definição de probabilidade baseada em frequências:

$P(A)=\lim _{n \rightarrow \infty} \frac{\# A}{n}$

Onde \#A se refere à quantidade de eventos A e n é o tamanho da amostra. Logo, com base no texto acima descrito, pode-se dizer que:

$P(A)=0,6$

Não obstante, tem-se que:

$P(B)=0,9$

Logo, o objetivo do problema pode-se resumir a estimar:

$P(A \mid B)$

Ou seja, a probabilidade de A condicionada ao evento B. Se a mesma for maior do que $50 \%$, um indivíduo racional optará por dizer que o $11^{\circ}$ cliente aceitará renegociar a dívida.

Do cálculo de probabilidades, tem-se que se A e B são independentes (tal como descrito no corpo da questão):

$P(A \mid B)=P(A)$

Assim: 
$P(A \mid B)=0,6$

O que faria com que um indivíduo racional optasse por dizer que o novo cliente aceitaria renegociar a dívida.

Entretanto, como Tversky e Kahneman (1974) explanam, em situações de incerteza, muitas vezes os indivíduos recorrem à heurística da representatividade para tomar suas decisões, isto é, o quão próximo um fenômeno está de algo análogo. Logo, se os respondentes realmente usaram tal heurística para consubstanciar seu processo decisório, é de se esperar que eles assinalem que o $11^{\circ}$ cliente não aceitará renegociar sua dívida, tendo em vista que ele é do mesmo setor e passa por situação financeira análoga ao outro cliente que não aceitou renegociar suas dívidas. Essa é a hipótese 9 dessa tese.

Isso implica que se essa hipótese não for refutada, a proporção de indivíduos que dirão que o $11^{\circ}$ cliente não aceitará renegociar sua dívida é estatisticamente maior do que a proporção de sujeitos que assinalarão que o $11^{\circ}$ cliente aceitará renegociar sua dívida, mesmo na presença de informações sobre independência dos conjuntos e suas implicações nas probabilidades $a$ priori.

\subsection{Questão 8}

A última questão do questionário assumia que o respondente havia compilado os resultados dos últimos dez exercícios de uma empresa. Adicionalmente, era salientado que o preço da ação apresentava uma correlação de 0,96 com o resultado do exercício, de modo que todos os resultados de exercício se encontravam discriminados.

Assim sendo, perguntava-se se o indivíduo compraria a ação da empresa. Analisando os dados fornecidos pela questão, além da notória alta correlação positiva com o preço da ação, notavam-se dois importantes aspectos:

1) O menor resultado do exercício era relativo ao último período, sendo de $\mathrm{R} \$ 400,00$ (em milhões de reais); 
2) O resultado do exercício flutuava em torno de uma média que era de $\mathrm{R} \$ 673,00$ (em milhões de reais).

A figura abaixo ilustra os aspectos ressaltados:

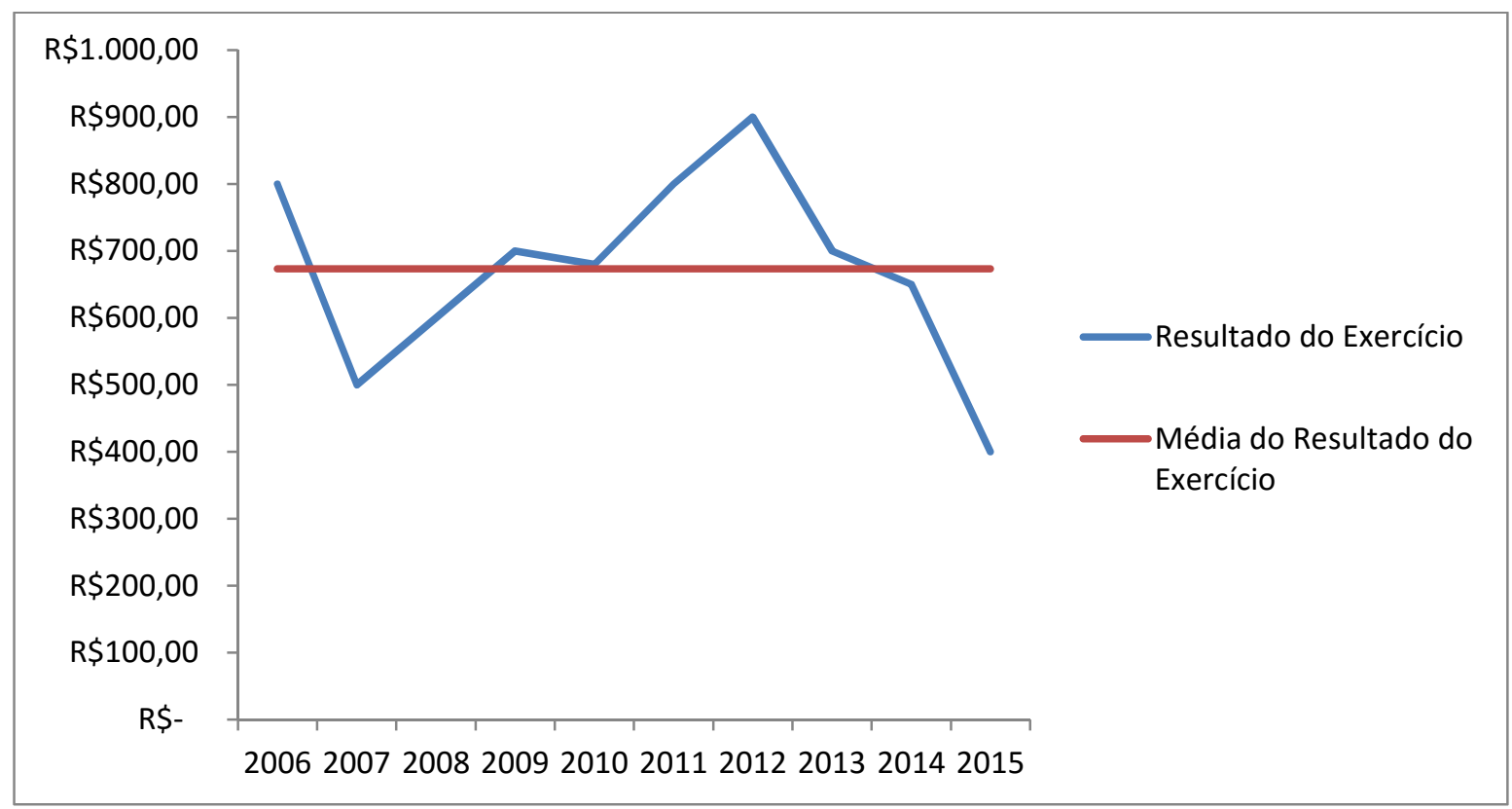

Figura 4 - Série Temporal dos Resultados do Exercício (Questão 8)

Como se vislumbra, a série apresenta traços de estacionariedade na média, tendo em vista que a mesma flutua sobre a média dos resultados dos exercícios. Aplicando o teste de KPSS (Kwiatkowski et al, 1992) para a respectiva série, pode-se verificar que o mesmo apresentou as seguintes estatísticas do teste para as ordens de defasagens:

Tabela 1 - Estatísticas do Teste KPSS para a Série Temporal da Questão 8

\begin{tabular}{|c|c|}
\hline Ordem da Defasagem & Estatística do Teste \\
\hline 0 & 0,146 \\
\hline 1 & 0,120 \\
\hline 2 & 0,118 \\
\hline 3 & 0,134 \\
\hline 4 & 0,176 \\
\hline 5 & 0,249 \\
\hline 6 & 0,344 \\
\hline
\end{tabular}


Tendo em vista que a hipótese nula do teste é a de que a série temporal é estacionária com tendência e de que a estatística crítica para 5\% de significância é de 0,146, pode-se afirmar que para um nível de significância de 5\%, a série temporal de resultado do exercício é estacionária em média para defasagens de até $3^{\mathrm{a}}$ ordem.

Segundo Tversky e Kahneman (1974), a heurística da representatividade também influencia na dificuldade dos indivíduos capturarem o efeito de regressão à média, o que ajuda a causar explicações causais espúrias.

Desse modo, essa questão buscou justamente capturar se havia a dificuldade de observar o efeito de regressão à média por parte dos respondentes, sendo a hipótese 10 dessa tese. Para que a mesma não seja refutada, a proporção de respondentes que não comprariam a ação dessa empresa deve ser estatisticamente maior do que a proporção dos indivíduos que comprariam. Tal fato ocorre, pois esses indivíduos olhariam para a informação mais recente (ponto de mínimo da série) e dariam maior peso a essa informação. Por sua vez, os indivíduos que vissem o efeito de regressão à média tenderiam a comprá-la, pois julgariam que a mesma cresceria para voltar à média, ceteris paribus.

\subsubsection{Sobre os procedimentos estatísticos aplicados}

A seguir, são detalhados os procedimentos estatísticos empregados na análise dos resultados dessa tese. Conforme discorrido anteriormente, são feitos testes de hipóteses de proporção com vistas a verificar se as hipóteses acima discorridas podem ser refutadas.

Não obstante, o questionário também apresenta itens que buscavam traçar o perfil social dos respondentes. Com vistas a levantar quais características influenciam os respondentes a assinalarem as alternativas previstas pela Prospect Theory, foram feitas regressões logísticas (para cada questão) onde o evento da variável resposta era a alternativa propugnada pela teoria que embasa essa tese.

Vale a pena complementar que em virtude dos questionários terem sido aplicados a alunos e analistas de mercado, seria imprudente juntar ambas as amostras e analisá-las de modo unificado. Logo, todas as estatísticas descritivas, testes de hipóteses e regressões logísticas 
são feitas de modo separado, com vistas a levantar como os achados variam entre alunos e analistas de mercado.

\subsection{Testes de Hipóteses Aplicados para Análise das Questões 1, 4, 5, 7 e 8}

Para cada uma das hipóteses 1, 2, 3, 6, 7, 9 e 10, foi feito um teste de hipóteses de proporção da população.

Assim sendo, seja i, o i-ésimo viés ou heurística estudada e definindo $p_{i}$ como a proporção observada de indivíduos que responderam o esperado pela Prospect Theory. Definindo $\mathrm{p}_{0}$ como a proporção a ser testada, tem-se o seguinte teste de hipóteses:

$H_{0}: p_{i}=p_{0}$

$H_{a}: p_{i}>p_{0}$

Para esta tese, foram feitos testes de hipóteses para $\mathrm{p}_{0}=0,5$ e $\mathrm{p}_{0}=0,75$. Com isso, buscou-se verificar, a um dado nível de significância, se a proporção de indivíduos que responderiam de acordo com a Prospect Theory seriam maiores do que $50 \%$ ou $75 \%$ em termos populacionais.

A não rejeição da hipótese para $\mathrm{p}_{0}=0,5$ implica que os indivíduos não respondem de acordo com o esperado pela Prospect Theory. Adicionalmente, se a hipótese for rejeitada para $\mathrm{p}_{0}=$ 0,5 , mas não para $\mathrm{p}_{0}=0,75$, há indícios de que na população, a maioria dos indivíduos responde de acordo com a Prospect Theory. A rejeição da hipótese também para $\mathrm{p}_{0}=0,75$ implica que há indicativos de que a população se comporta de maneira bem forte ao previsto pela Prospect Theory.

Conforme Anderson et al. (2008) explicam, a estatística do teste é dada por:

$z_{i}=\frac{p_{i}-p_{0}}{\sqrt{\frac{p_{0}\left(1-p_{0}\right)}{n}}}$

Em que $n$ é o tamanho da amostra e $z_{i}$ se refere ao argumento da função distribuição de probabilidade normal padrão para o i-ésimo teste. 


\subsection{Testes de Hipóteses Aplicados para Análise das Questões 2, 3 e 6}

As hipóteses 4, 5 e 8 envolviam duas versões de uma mesma questão. Logo, fez-se necessário aplicar um teste de hipóteses que permitisse a inferência sobre a diferença entre as proporções de duas populações, tendo em vista que o objetivo é testar se a proporção de indivíduos que responderam uma alternativa numa versão é estatisticamente maior do que a proporção de indivíduos que a responderam na outra versão.

Definindo $\mathrm{p}_{1 \mathrm{i}}$ como a proporção de indivíduos que responderam a alternativa propugnada pela Prospect Theory na versão 1 da i-ésima hipótese e definindo $\mathrm{p}_{2 \mathrm{i}}$ como a proporção de indivíduos que responderam a mesma alternativa na versão 2 da i-ésima hipótese, tem-se o seguinte teste de hipóteses

$$
\begin{aligned}
& H_{0}: p_{1 i}-p_{21}=0 \\
& H_{a}: p_{1 i}-p_{21} \neq 0
\end{aligned}
$$

De acordo com Anderson et al. (2008), a estatística do teste é assim dada:

$$
z_{i}=\frac{\left(p_{1 i}-p_{2 i}\right)}{\sqrt{p_{i}\left(1-p_{i}\right)\left(\frac{1}{n_{1}}+\frac{1}{n_{2}}\right)}}
$$

Em que:

$p_{i}=\frac{n_{1} p_{1 i}+n_{2} p_{2 i}}{n_{1}+n_{2}}$

$\mathrm{E} \mathrm{n}_{1}$ e $\mathrm{n}_{2}$ são respectivamente o tamanho das amostras de indivíduos que responderam a $1^{\mathrm{a}}$ versão e $2^{\mathrm{a}}$ versão. Adicionalmente, $\mathrm{z}_{\mathrm{i}}$ se refere ao argumento da função distribuição de probabilidade normal padrão para o i-ésimo teste. Todos os testes de hipóteses foram feitos considerando um nível de significância de 5\% no software Stata ${ }^{\circledR} 14$.

\subsection{Regressões Logísticas}


Para todas as hipóteses dessa tese, são feitas regressões logísticas que buscam levantar quais das variáveis de perfil social podem explicar os indivíduos responderem tal como o propugnado pela Prospect Theory.

De acordo com Fávero (2015), “a regressão logística binária tem como objetivo principal estudar a probabilidade de ocorrência de um evento definido por Y que se apresenta na forma qualitativa dicotômica", isto é, $Y$ descreve a ocorrência $(Y=1)$ ou não ocorrência de uma característica de interesse $(\mathrm{Y}=0)$. No caso dessa tese, $\mathrm{Y}$ representa se o indivíduo respondeu tal como previsto pela Prospect Theory ou não.

Conforme Fávero (2015) explica, a regressão logística assume que o logaritmo neperiano da chance é escrito como combinação linear do vetor de variáveis explicativas, ou seja:

$\ln (\text { chance })_{Y=1}=\alpha+\beta_{1} X_{1 i}+\beta_{2} X_{2 i}+\ldots+\beta_{n} X_{k i}$

Em que $\alpha$ representa o intercepto, $\beta_{\mathrm{j}}(\mathrm{j}=1,2, \ldots, \mathrm{k})$ são os parâmetros estimados para cada uma das $\mathrm{k}$ variáveis explicativas, $\mathrm{X}_{\mathrm{k}}$ são as variáveis explicativas (podendo ser dummies ou não) e i se refere a cada observação da amostra de tamanho n.

Por sua vez, Fávero (2015) explica que o conceito de chance é assim definido:

chance $_{Y=1}=\frac{p_{i}}{1-p_{i}}$

Em que $p_{i}$ se refere à probabilidade do i-ésimo indivíduo ser evento.

É importante comentar que o logaritmo neperiano da chance é conhecido na literatura como logito ou logit, ou seja:

$\ln \left(\frac{p_{i}}{1-p_{i}}\right)=Z_{i}$

Assim: 
$\ln \left(\frac{p_{i}}{1-p_{i}}\right)=Z_{i}=\alpha+\beta_{1} X_{1 i}+\beta_{2} X_{2 i}+\ldots+\beta_{n} X_{k i}$

Com isso, isolando $\mathrm{p}_{\mathrm{i}}$, chega-se à expressão da probabilidade de um dado indivíduo ser evento, isto é:

$p_{i}=\frac{1}{1+e^{-\left(\alpha+\beta_{1} X_{1 i}+\beta_{2} X_{2 i}+\ldots+\beta_{n} X_{k i}\right)}}=\frac{1}{1+e^{-Z_{i}}}=\frac{e^{Z_{i}}}{1+e^{Z_{i}}}$

De modo análogo, tem-se que:

$1-p_{i}=\frac{1}{1+e^{Z_{i}}}$

Segundo Fávero (2015), para se estimar o vetor de parâmetros $\alpha, \beta_{1}, \ldots, \beta_{\mathrm{k}}$, a regressão logística utiliza a estimação por máxima verossimilhança.

Assim sendo, seja Y o evento em interesse que segue uma distribuição de Bernoulli e seja $p_{i}$ a probabilidade da i-ésima observação ter incidido no evento de interesse ou não. Conforme discorrido acima, Y é uma variável aleatória que assume dois valores, isto é, 1 (ocorrência do evento) e 0 (não ocorrência do evento). Logo, pode-se escrever a probabilidade da i-ésima observação ser evento como:

$p\left(Y_{i}\right)=p_{i}^{Y_{i}}\left(1-p_{i}\right)^{1-Y_{i}}$

Assumindo que as $\mathrm{n}$ observações são independentes, pode-se estimar a função de verossimilhança como sendo:

$L=\prod_{i=1}^{n}\left[p_{i}^{Y_{i}}\left(1-p_{i}\right)^{1-Y_{i}}\right]$

Substituindo a definição do logit vista acima, chega-se à:

$L=\prod_{i=1}^{n}\left[\left(\frac{e^{Z_{i}}}{1+e^{Z_{i}}}\right)^{Y_{i}}\left(\frac{1}{1+e^{Z_{i}}}\right)^{1-Y_{i}}\right]$ 
O objetivo então passa a achar o vetor de parâmetros $\alpha, \beta_{1}, \ldots, \beta_{\mathrm{k}}$ que maximize a função acima definida, através de um sistema não linear obtido através das derivadas parciais de cada elemento.

Entretanto, a presença do produtório de $\mathrm{n}$ termos na função de verossimilhança acima definida complica essa tarefa, na medida em que a derivada parcial de um produto não é meramente o produto da derivada parcial de cada um dos $n$ termos.

Assim sendo, é usual tomar o logaritmo neperiano da função de verossimilhança, tendo em vista que a função logarítmica é monotônica e preserva os máximos estimados. Assim sendo, ao se tomar o logaritmo e utilizando suas propriedades, o cálculo das derivadas parciais se torna mais prático, na medida em que função logaritmo de máxima verossimilhança passa a ser assim representada:

$L L=\sum_{i=1}^{n}\left[\left(Y_{i}\right) \cdot \ln \left(\frac{e^{Z_{i}}}{1+e^{Z_{i}}}\right)\right]+\left[\left(1-Y_{i}\right) \cdot \ln \left(\frac{1}{1+e^{Z_{i}}}\right)\right]$

Logo, achar o máximo de LL equivale a resolver o seguinte sistema não linear:

$$
\begin{aligned}
& \frac{\partial L L}{\partial \alpha}=0 \\
& \frac{\partial L L}{\partial \beta_{1}}=0 \\
& \vdots \\
& \frac{\partial L L}{\partial \beta_{k}}=0
\end{aligned}
$$

Como o sistema é não-linear, faz-se necessário o emprego de técnicas numéricas como o método de Newton-Raphson, empregado em softwares econométricos como o Stata ${ }^{\circledR} 14$, que foi utilizado nessa tese.

Após a obtenção dos parâmetros desejados, é conveniente verificar se os mesmos são estatisticamente significativos, isto é, se a um dado nível de significância previamente adotado, pode-se garantir que o parâmetro estudado seja diferente de 0 . 
Inicialmente, é feito um teste de hipóteses que busca verificar se existe ao menos um parâmetro estatisticamente diferente de 0 , isto é:

$H_{0}: \beta_{1}=\cdots=\beta_{k}=0$

$H_{a}: \exists i$ tal que $\beta_{i} \neq 0,1 \leq i \leq k$

Seja $\mathrm{LL}_{0}$ a função logaritmo de verossimilhança quando o modelo é nulo, isto é, quando ele é composto somente pela constante $\alpha$ e seja $\mathrm{LL}_{\text {Max }}$ como o máximo da função obtida a priori. De acordo com Fávero (2015), utilize-se a seguinte estatística que segue uma distribuição quiquadrado com $\mathrm{k}$ graus de liberdade para se fazer o teste de hipóteses.

$\chi_{k g . l .}^{2}=-2 .\left(L L_{0}-L L_{m a ́ x}\right)$

Se a estatística calculada estiver na zona de rejeição da hipótese nula previamente definida, pode-se dizer que há ao menos uma variável estatisticamente significativa, ou seja, rejeita-se a hipótese nula desse teste.

Após tal etapa, faz-se necessário verificar qual variável é estatisticamente significativa, que é feito através do teste de hipóteses de Wald. Com isso, para cada parâmetro estimado, faz-se o seguinte teste de hipóteses:

$$
\begin{aligned}
& H_{0}: \beta_{i}=0 \\
& H_{a}: \beta_{i} \neq 0
\end{aligned}
$$

A estatística do teste utiliza a distribuição normal padrão e é dada por:

$z_{\beta_{i}}=\frac{\beta_{i}}{\text { s.e. }\left(\beta_{i}\right)}$

Em que s.e. $\left(\beta_{i}\right)$ é o erro-padrão do parâmetro estimado. Se a estatística calculada estiver dentro da zona de rejeição para um dado nível de significância previamente definido, rejeitase a hipótese nula de que o parâmetro é igual a 0 (em termos populacionais). 
Essa tese utilizou o procedimento de backward stepwise com um nível de significância de $5 \%$, ou seja, para cada modelo de regressão logística, era feito uma regressão com todas as variáveis. Após a primeira regressão, retiravam-se as variáveis não estatisticamente significativas, isto é, aquelas em que não se rejeitava a hipótese nula do teste de Wald. Uma nova regressão era feita e faziam-se novos testes, de modo que iterava-se até que estivessem somente com as variáveis estatisticamente significativas. Todos os cálculos foram realizados no Stata ${ }^{\circledR} 14$.

Algumas medidas de qualidade de modelo foram calculadas para todos os modelos feitos. A primeira delas é conhecida como pseudo $\mathrm{R}^{2}$ de McFadden. Segundo Fávero (2015), sua expressão é dada por:

pseudo $R^{2}=\frac{-2 \cdot\left(L L_{0}-L L_{m a ́ x}\right)}{-2 L L_{0}}$

Apesar de a mesma ter sido calculada nessa tese para fins ilustrativos, sua aplicação é limitada (Fávero, 2015).

Assim sendo, uma medida mais robusta foi empregada. Para tanto, inicialmente é necessário definir um ponto de corte de cada modelo. Seja $\mathrm{p}_{\mathrm{i}}$ a probabilidade do i-ésimo caso ser evento. Se a mesma é maior ou igual do que a probabilidade de corte previamente definida, tal caso é classificado como evento. Se for menor, é classificado como não evento.

Para cada ponto de corte, é possível definir uma matriz de confusão $2 \times 2$ que busca relacionar a classificação do modelo com os dados efetivamente observados (variável aleatória Y), tal como visto abaixo:

Tabela 2 - Exemplo de Matriz de Confusão para um Dado Ponto de Corte

\begin{tabular}{|l|c|c|}
\hline & Incidência Real do evento & Incidência Real do Não Evento \\
\hline Classificado como Evento & $\mathrm{a}_{11}$ & $\mathrm{a}_{12}$ \\
\hline Classificado como Não Evento & $\mathrm{a}_{21}$ & $\mathrm{a}_{22}$ \\
\hline
\end{tabular}

Assim sendo, convém determinar duas medidas. A primeira delas é conhecida na literatura como sensitividade e diz respeito à proporção de casos classificados como eventos dentre o total de eventos efetivamente observados. A segunda, por sua vez, é denominada 
especificidade e se refere à proporção de casos classificados como não eventos dentre o total de não eventos efetivamente observados, isto é:

Sensitividade $=\frac{a_{11}}{a_{11}+a_{21}}$

Especificidade $=\frac{a_{22}}{a_{21}+a_{22}}$

Esta tese calculou para todos os modelos uma medida que considera todas as sensitividades e especificidades possíveis de serem obtidas com todos os pontos de corte (área embaixo da curva Receiver Operatig Characteristic - ROC). Esta medida tem como objetivo verificar quão bem o modelo é capaz de discriminar o evento do não evento.

Segundo Fávero (2015), a curva ROC mostra o comportamento do conflito entre a sensitividade e a especificidade para os diferentes pontos de core, isto é, quando um aumenta, o outro diminui. Como ambas as variáveis possuem direção contrária, é feito um gráfico convexo que relaciona a sensitividade (no eixo das ordenadas) com 1- especificidade (no eixo das abscissas). Se não houver discriminação alguma, esse gráfico gerará uma reta. Caso contrário, a curva será convexa. Desse modo, a área embaixo da curva ROC é definida como a área da curva convexa obtida com o modelo. O gráfico abaixo discrimina um exemplo de curva ROC:

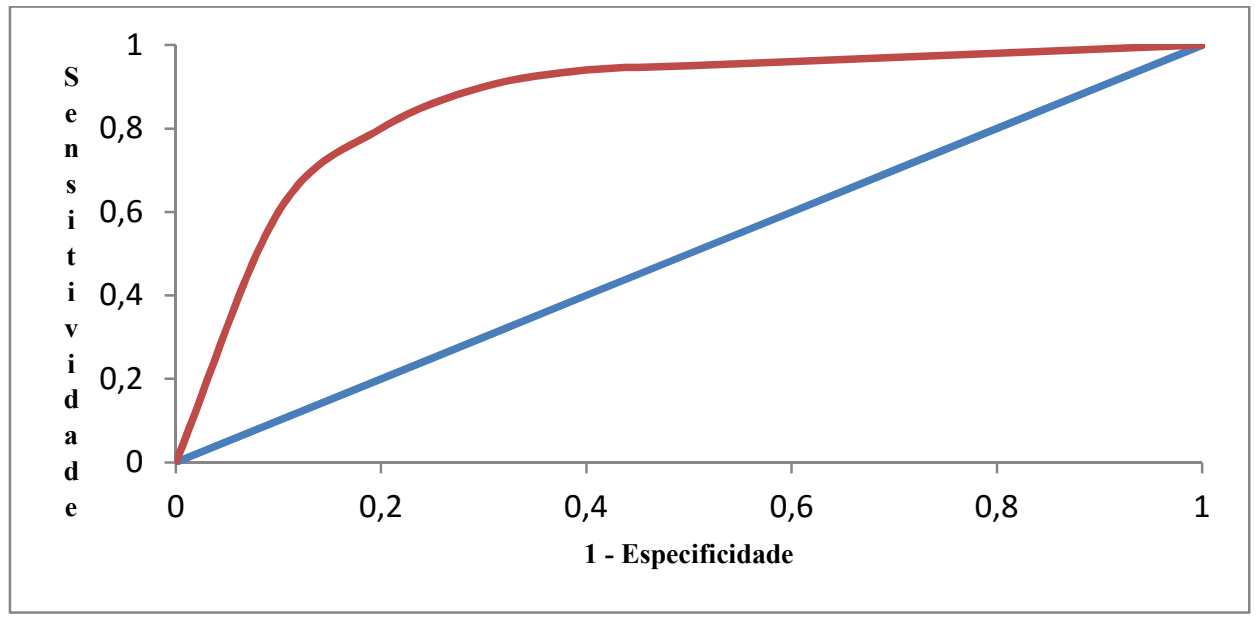

Figura 5 -Um Exemplo de curva ROC 
Esta medida varia entre 0,5 e 1, onde 0,5 representa a ausência completa de discriminação e 1 representa a discriminação perfeita.

Entretanto, essa tese não teve como objetivo criar modelos preditivos, o que traz um menor peso relativo às medidas de desempenho como o pseudo $\mathrm{R}^{2} \mathrm{e}$ a área embaixo da curva ROC. Desse modo, foram estimadas as Odds Ratio (razões de chance) para todas as variáveis estatisticamente significativas de todos os modelos. De acordo com Fávero (2015), para a iésima variável, sua fórmula é dada por:

$e^{\beta_{i}}=$ Odds Ratio $_{i}$

Interpreta-se a mesma da seguinte maneira: ceteris paribus e na presença das demais variáveis, a chance se incorrer no evento é (1-Odds Ratio $) \%$ maior ou menor quando comparada à categoria de referência. Se a variável for quantitativa, este percentual se refere para um acréscimo de 1 unidade da variável.

\subsubsection{Limitações da Pesquisa}

Esta tese apresenta algumas limitações no que diz respeito à aplicação empírica da pesquisa. Dado a dificuldade em contatar analistas de uma instituição financeira para responder ao questionário, os resultados se limitam aos profissionais de uma grande instituição financeira do Brasil em particular. Ainda assim, obter essa amostra de profissionais foi uma tarefa de grande dificuldade, na medida em que essas pessoas possuem uma agenda muito atarefada. Logo, apenas 55 indivíduos responderam ao questionário, apesar do mesmo ter sido enviado para mais de 120 profissionais da mesma empresa.

Não obstante, ciente de que poucos indivíduos responderiam ao questionário, esta pesquisa optou também por trabalhar com os estudantes de uma das melhores faculdades de negócio do Brasil como uma forma de ampliar o escopo de análise: a faculdade de Economia, Administração e Contabilidade da Universidade de São Paulo.

Apesar da amostra de profissionais e de estudantes possuir limitações e vieses inerentes a sua obtenção, esta tese partiu da seguinte premissa: se os vieses e heurísticas fossem observados para indivíduos de duas renomadas instituições (em termos acadêmicos e de mercado 
financeiro), há de se supor que eles ocorram com sujeitos que não tenham sua atuação acadêmica e profissional atreladas às instituições de tanto renome quanto as utilizadas nessa tese.

Com isso, apesar do poder inferencial da tese estar limitado em virtude das conveniências amostrais, os achados não perdem relevância e podem ensejar uma agenda de pesquisas futuras.

Outra limitação importante da pesquisa efetuada diz respeito ao instrumento de medida utilizado, isto é, o questionário. Tendo em vista a dificuldade de selecionar indivíduos que estivessem dispostos a participar da pesquisa, não foi possível fazer um pré-questionário para levantar possíveis inconsistências na sua aplicação. Como forma de tentar combater esse problema, o questionário foi inicialmente aplicado com os estudantes da FEA/USP para verificar possíveis inconsistências, antes de ser aplicado junto aos profissionais. Não se noticiou nenhum ponto que merecesse uma mudança substancial na aplicação do questionário entre os dois públicos. Logo, esse problema foi dirimido, mas não totalmente consertado.

Finalmente, outro aspecto que merece ser ressaltado diz respeito à presença do pesquisador na aplicação dos questionários. Para evitar com que os sujeitos conversassem entre si e eventualmente influenciassem um a decisão do outro, foi feita uma recomendação expressa para que o questionário fosse respondido individualmente. Adicionalmente, para evitar com que o participante pudesse se sentir constrangido com suas respostas, foi dito que não existiam respostas certas e erradas. É importante ressaltar que nenhum participante sabia que a tese envolvia o estudo de vieses e heurísticas no seu processo decisório. Se estes soubessem o real objetivo da pesquisa a priori, suas respostas poderiam mudar substancialmente, pois eles tentariam agir de modo não natural, de modo a tentar demonstrar que não estariam suscetíveis aos vieses e heurísticas discorridas no corpo dessa tese. 


\section{Resultados}

Neste capítulo, são apresentados os resultados da pesquisa efetuada. Para tanto, os resultados são divididos em termos do perfil dos respondentes, isto é, inicialmente são discutidos os resultados obtidos com os estudantes da Faculdade de Economia, Administração e Contabilidade da Universidade de São Paulo. Posteriormente, abordam-se os achados encontrados com os analistas de mercado de capitais de uma importante instituição financeira brasileira. Para cada seção, são apresentados os seguintes resultados: estatística descritiva do perfil dos respondentes, testes de hipóteses realizados e regressões logísticas. Após os resultados serem apresentados, um compêndio dos principais resultados é levantado.

\subsection{Estudantes da Faculdade de Economia, Administração e Contabilidade da Universidade de São Paulo}

Conforme comentando a priori, este item discorre sobre os resultados verificados junto aos estudantes da Faculdade de Economia, Administração e Contabilidade da Universidade de São Paulo.

\subsubsection{Perfil dos Respondentes - Estatísticas Descritivas}

Foram submetidos 369 questionários aos estudantes da Faculdade de Economia, Administração e Contabilidade da Universidade de São Paulo (FEA/USP). Destes, 237 eram homens $(64,23 \%)$. Isso denota que a maioria dos respondentes era do sexo masculino, o que pode sugerir que em termos gerais, o perfil da amostra seja composta por pessoas com menor aversão ao risco, dado que existem indícios de que as mulheres possuem mais aversão ao risco do que os homens (Dantas e Macedo, 2013).

No tocante ao estado civil dos respondentes, 340 se declararam como solteiro $(92,39 \%)$, ao passo que somente $26(7,07 \%)$ eram casados e $2(0,54 \%)$ eram divorciados. Vale a pena relatar que houve um único missing value, ou seja, um indivíduo não assinalou qual era seu estado civil. Assumindo que pessoas casadas tendem a atuar mais preponderantemente como chefes de família, pode-se conjecturar que essas sejam menos propensas a tomarem riscos do que os solteiros. 
Abaixo, encontra-se histograma feito com a variável idade com os respondentes do questionário. É importante relatar que para esta variável, existiram cerca de 20 missing values.

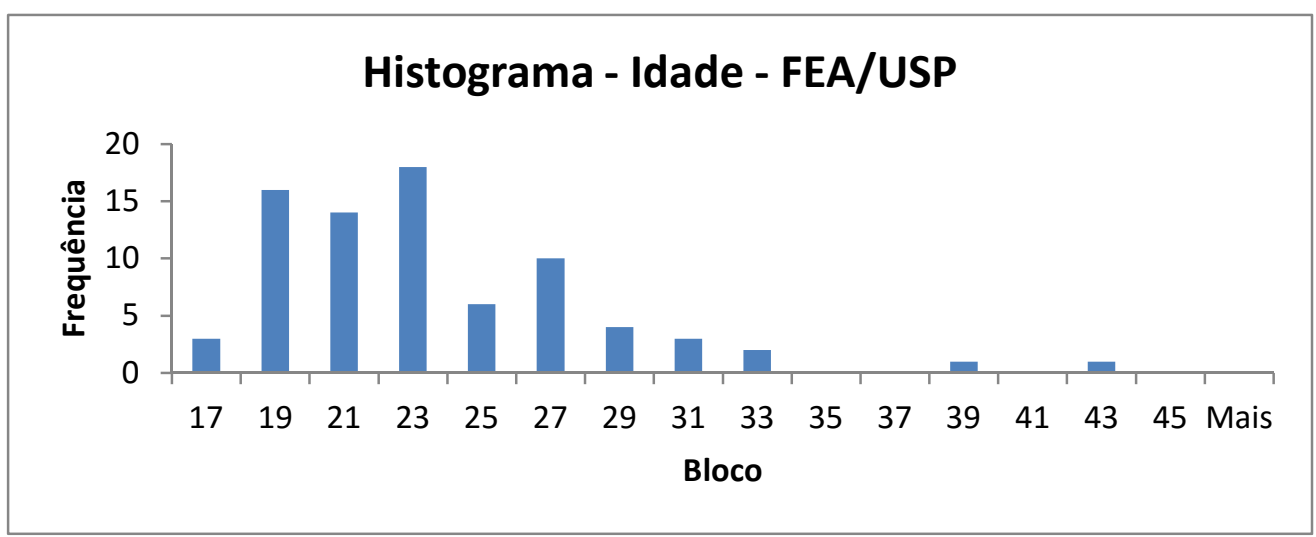

Figura 6 - Histograma de Idade (Alunos FEA/USP)

Como se vislumbra com o histograma, percebe-se que os indivíduos, em sua grande maioria, eram jovens. As estatísticas descritivas colaboram com essa asserção, na medida em que se observam os seguintes percentis:

Tabela 3 - Percentis da Variável Idade para os estudantes da FEA/USP

\begin{tabular}{|c|c|}
\hline Percentil & Idade \\
\hline $1 \%$ & 17 \\
\hline $5 \%$ & 18 \\
\hline $10 \%$ & 18 \\
\hline $25 \%$ & 19 \\
\hline $50 \%$ & 21 \\
\hline $75 \%$ & 24 \\
\hline $90 \%$ & 29 \\
\hline $95 \%$ & 32 \\
\hline $99 \%$ & 43 \\
\hline
\end{tabular}

A análise da distribuição dos percentis mostra que até $50 \%$ da amostra é composta por indivíduos com até 21 anos de idade. Raciocinando de modo estritamente análogo, assinala-se que $75 \%$ da amostra é composta por indivíduos de até 24 anos. Assim sendo, verifica-se que a variável idade apresenta grande assimetria com cauda à direita, conforme o histograma revela. O coeficiente de assimetria de Pearson para a variável é de 2,15 , confirmando o achado geométrico acima relatado.

No tocante ao primeiro momento da variável aleatória em questão, a mesma apresentou uma média de 22,63 anos. Já a variância foi de 27,08 anos ao quadrado, o que leva a um desvio- 
padrão de 5,20 anos. Não obstante, o mínimo obtido foi de 17 anos, ao passo em que o máximo foi de 52 anos.

O perfil mais jovem dessa amostra também corrobora com a ideia de que essa amostra seja menos avessa ao risco do que outras.

Fortalecendo a análise feita acima, 361 respondentes (97,83\%) não possuíam nenhum filho, enquanto que $6(1,63 \%)$ possuíam um único filho e $2(0,54 \%)$ possuíam 2 filhos.

Logo, em termos gerais, os estudantes da amostra eram jovens, solteiros e sem filhos, o que sinaliza de que estes possam ser menos avessos ao risco.

Discutindo sobre o perfil acadêmico propriamente dito dos mesmos, 256 eram alunos do bacharelado em Ciências Contábeis (70,72\%), 80 eram do bacharelado em Ciências Econômicas (22,10\%) e 21 eram do bacharelado em Ciências Atuarias (5,80\%). Os demais indivíduos eram alunos intercambistas ou de outros cursos da Universidade de São Paulo. Vale a pena complementar que 7 indivíduos não responderam a questão, configurando-se como missing value.

Analisando o perfil acadêmico, vislumbra-se que a maioria dos sujeitos que responderam o questionário serão futuros contadores. Como todos os vieses e heurísticas testados estavam envoltos em cenários que faziam uso do conhecimento contábil, pode-se argumentar que as hipóteses que não foram rejeitadas podem indicar que mesmo o ensino formal de Ciências Contábeis não é suficiente e que alguns vieses estão mais associados a natureza humana e que mesmo o ensino formal não é suficiente para evitar com que os indivíduos respondam de modo enviesado.

Adicionalmente, 258 respondentes eram alunos do período noturno $(70,30 \%)$, o que poderia sugerir que muitos indivíduos já poderiam atuar profissionalmente. Entretanto, somente 164 indivíduos já trabalham ou estagiam (44,44\%), ao passo que os outros $205(55,56 \%)$ ainda não trabalham ou estagiam. É importante relatar que 109 estudantes são do período diurno (29,70\%). Complementarmente, 2 respondentes não responderam em qual período estudam. 
Um dos objetivos dessa tese é justamente verificar se a baixa experiência profissional pode contribui ou não para que os indivíduos decidam de modo enviesado e fazendo uso de heurísticas.

No tocante aos respondentes que trabalham, verifica-se que pelo menos 30\% dos indivíduos ainda trabalham ou estagiam há menos de 1 ano, ao passo que 50\% dos respondentes trabalham somente há pelo menos 2 anos, fortalecendo a visão de que a amostra é composta por um perfil extremamente jovem e inexperiente de indivíduos.

Dos 369 respondentes, 9 não indicaram em que ano de estudo se encontram. Nesse sentido, a amostra foi composta por 157 pessoas que estavam no primeiro ano de Ensino Superior (46,61\%), 57 no segundo ano $(15,83 \%), 65$ no terceiro ano $(18,06 \%), 42$ no quarto ano $(11,67 \%), 27$ no quinto ano $(7,50 \%)$ e os demais com pelo menos 6 anos de estudo. Posteriormente, é testado se o fato do indivíduo ser mais veterano faz diferença ou não na possibilidade de as hipóteses serem rejeitadas ou não.

Não obstante, somente 40 respondentes $(10,84 \%)$ já participaram de programas de iniciação científica. Essa tese também testa se a iniciação científica faz alguma diferença no estudo dos vieses e heurísticas considerados.

Vale a pena fazer uma observação sobre a iniciação científica. Estudando quando os indivíduos fizeram suas iniciações científicas, vislumbrou-se que cerca de $30 \%$ dos 40 indivíduos fizeram iniciação científica em outra graduação, enquanto que a outra parte fez nos seus primeiros anos de sua graduação.

Cerca de 72 sujeitos (19,51\%) apresentavam outra formação. Desses, 69 assinalaram qual era a outra formação. Desses, 16 indivíduos (23,19\%) tinham outra formação em uma área correlata de ciências sociais aplicadas, isto é, Ciências Contábeis, Ciências Atuarias, Ciências Econômicas e Administração de Empresas. Por sua vez, 14 eram engenheiros (20,29\%) e 6 tinham feito Direito $(8,70 \%)$. Os demais possuíam formações diversas.

A seguir, são feitos os testes de hipóteses e as regressões logísticas discorridas no capítulo de metodologia para a amostra composta pelos alunos da Faculdade de Economia, Administração e Contabilidade da Universidade de São Paulo. 


\subsubsection{Questão 1 - Estudantes da Faculdade de Economia, Administração e Contabilidade da Universidade de São Paulo}

Conforme discorrido anteriormente, através da questão 1, foram testadas as hipóteses 1, 2 e 3 dessa tese.

A hipótese 1 estava intimamente associada à decisão 1 da questão 1 do referido questionário. Ela argumentava que a proporção de indivíduos que optaram por recomendar a venda das ações agora e realizar o lucro de $\mathrm{R} \$ 10,00$ por ação é maior estatisticamente do que os indivíduos que prefeririam recomendar a venda da ação no final do ano.

Verificando as estatísticas descritivas referentes a essa primeira questão, somente 176 $(47,70 \%)$ da amostra assinalaram que optariam por recomendar a venda das ações no presente momento. Isso se configura como um forte indício de que a hipótese 1 dessa tese pode ser rejeitada para o universo de alunos da FEA/USP.

Fazendo o teste de hipóteses apropriado para $\mathrm{p}_{0}=0,5$, testou-se se a proporção de indivíduos que assinalaram de acordo com a hipótese 1 era estatisticamente igual a 50\%. Para a hipótese alternativa $\mathrm{p}_{0}>0,5$, foi obtido um $p$-value de 0,8119 . De modo estritamente análogo, para uma hipótese nula de $\mathrm{p}_{0}=0,75$ e uma alternativa de $\mathrm{p}_{0}>0,75$, foi encontrado um $p$-value de 1,000 .

Com isso, não existem indícios de que a maioria dos alunos da FEA/USP estão sujeitos ao efeito certeza, tal como propugnado pela Prospect Theory de Kahneman e Tversky.

O próximo passo foi fazer uma regressão logística para buscar entender quais eram as variáveis que eram capazes de explicar o motivo de 47,70\% dos indivíduos responderem tal como o propugnado pela hipótese 1 .

Assim sendo, assumindo que a variável explicada do modelo é uma dummy que recebe 1 se o indivíduo respondeu conforme a hipótese 1 e 0 caso contrário, foi feita uma regressão logística pelo método stepwise através do procedimento Backward usando a estatística de Wald com um nível de significância de $5 \%$. Os procedimentos realçados nesse parágrafo foram adotados em todas as regressões logísticas dessa tese. Logo, este conjunto de informações não será repetido O conjunto de variáveis explicativas do modelo foi: 


\begin{tabular}{|l|l|l|}
\hline $\begin{array}{c}\text { Conjunto de Variáveis Explicativas - Regressão } \\
\text { Logística - Hip. 1 (efeito certeza)-FEA/USP }\end{array}$ & Categorias da Variável ou Escala de Medida & Categoria de Referência \\
\hline Gênero & Feminino ou Masculino & Feminino \\
\hline Estado Civil & $\begin{array}{l}\text { Solteiro(a), Casado(a), Divorciado(a) ou } \\
\text { Viúvo(a) }\end{array}$ & Casado \\
\hline Idade & Dado em anos & \\
\hline Número de Filhos & & \\
\hline Curso & $\begin{array}{l}\text { Ciências Contábeis, Ciências Econômicas, } \\
\text { Ciências Atuariais ou Outros }\end{array}$ & Outros \\
\hline Período do Curso & Diurno ou Noturno & Diurno \\
\hline Ano no Curso & Dado em anos & \\
\hline Trabalha ou Estagia & Sim ou Não & Não \\
\hline Há Quanto Tempo Trabalha & Dado em anos & Não \\
\hline Participou ou Participa de Iniciação Científica & Sim ou Não & Não \\
\hline Possui Outra Formação & Sim ou Não & Não \\
\hline Respondeu de acordo com a hipótese 2 & Sim ou Não & Não \\
\hline Respondeu de acordo com a hipótese 3 & Sim ou Não & Não \\
\hline Respondeu de acordo com a hipótese 6 & Sim ou Não & Não \\
\hline Respondeu de acordo com a hipótese 7 & Sim ou Não & Não \\
\hline Respondeu de acordo com a hipótese 9 & Sim ou Não & Não \\
\hline Respondeu de acordo com a hipótese 10 & Sim ou Não & \\
\hline
\end{tabular}

Quadro 3 - Conjunto de Variáveis Explicativas - Regressão Logística - Hip. 1 (efeito certeza)FEA/USP

É importante ressaltar que as hipóteses 4,5 e 8 foram construídas de modo diferente às hipóteses 2, 3, 6, 7, 9 ou 10, tal como verificado no capítulo de procedimentos metodológicos empregados, o que impossibilitou sua inclusão como variável explicativa nas regressões logísticas que envolvessem as hipóteses 1, 2, 3, 6, 7, 9 e 10.

O modelo logístico final foi o seguinte: 
Tabela 4 -Resultado da Regressão Logística - Hip. 1 (efeito certeza) - FEA/USP

\begin{tabular}{|c|c|c|c|c|c|}
\hline & $\begin{array}{l}\text { Coeficiente } \\
\text { estimado }\end{array}$ & Erro Padrão & $\mathrm{z}$ & $P$-value & $\begin{array}{c}\text { Intervalo de Confiança - } \\
95 \%\end{array}$ \\
\hline Sexo Masculino** & $-1,343735$ & 0,6024307 & $-2,23$ & 0,026 & {$[-2,524477 ;-1629923]$} \\
\hline Constante*** & 1,791759 & 0,5400617 & 3,32 & 0,001 & {$[0,7332579 ; 2,850261]$} \\
\hline \multicolumn{6}{|c|}{ Log likelihood-50,934917 } \\
\hline \multicolumn{6}{|l|}{ LR chi2 (1)5,90 } \\
\hline \multicolumn{6}{|l|}{ Prob $>$ chi20,0151 } \\
\hline \multicolumn{6}{|l|}{ Pseudo $R^{2} 0,0548$} \\
\hline Área Embaixo ROC & 0,6259 & & & & \\
\hline \multicolumn{6}{|c|}{ * Significante pelo menos a $10 \%$} \\
\hline \multicolumn{6}{|c|}{$* *$ Significante pelo menos a $5 \%$} \\
\hline$* * *$ Significante pelc & os a $1 \%$ & & & & \\
\hline
\end{tabular}

O mesmo apresentou uma área embaixo da curva Receive Operating Characteristic (ROC) de 0,6259, o que denota que o modelo não é capaz de discriminar muito bem o evento do não evento, conforme visto em gráfico abaixo.

Entretanto, o objetivo dessa tese não envolve a criação de modelos preditivos que buscariam classificar adequadamente os indivíduos que responderam cada questão de acordo com a Prospect Theory. Logo, o que realmente é estudado para todos os modelos da mesma são os sinais das variáveis estatisticamente significativas e seus respectivos Odds Ratio.

Calculando a Odds Ratio da variável sexo masculino, obtém-se que:

$e^{-1,343735}=0,2608696$

Logo, ceteris paribus e na presença das demais variáveis, pode-se dizer que um estudante do sexo masculino possuía uma chance $73,91 \%$ menor em relação às mulheres de assinalar de acordo com o propugnado pela hipótese 1. Esse achado é importante, na medida em que confirma a ideia de que as mulheres são mais conservadoras em relação aos homens, o que as levaria a recomendar a venda da ação nesse exato momento, mesmo que isso contrariasse o cálculo das esperanças matemáticas denotados anteriormente. Isto implica que para a amostra estudada, as pessoas do sexo feminino estão mais sujeitas ao efeito certeza discorrido a priori.

Após a discussão das implicações evidenciadas na hipótese 1, será abordada como a amostra de estudantes da FEA/USP se comportou diante de uma perda certa, isto é, a hipótese 2. 
Apenas 26,29\% responderam de acordo com o propugnado pela Prospect Theory, o que implica que somente 97 alunos arriscaram, recomendando a venda das ações somente no final do ano (decisão 2). Novamente, isso também reflete um fortíssimo indício de que não há como afirmar que os estudantes da FEA/USP se comportam tal como o propugnado pela Prospect Theory.

Analogamente, fazendo o teste de hipóteses apropriado para $\mathrm{p}_{0}=0,5$ e $\mathrm{p}_{0}=0,75$, testou-se se a proporção de indivíduos que assinalaram de acordo com a hipótese 2 era estatisticamente igual a $50 \%$ e $75 \%$ respectivamente. Para as hipóteses alternativas $\mathrm{p}_{0}>0,5$ e $\mathrm{p}_{0}>0,75$, os $p$ values de ambos os testes foram de 1,0000 e 1,0000 respectivamente. Logo, não se pode rejeitar, a um nível de significância de $5 \%$ de que de que a verdadeira proporção dentre os estudantes da Faculdade de Economia, Administração e Contabilidade da Universidade de São Paulo seja sequer igual a 50\%. Logo, assumindo um erro do tipo I de 5\%, não há indícios de que a maioria dos alunos da FEA/USP estejam sujeitos ao efeito reflexão tal como propugnado pela Prospect Theory.

Tal como na hipótese 1, também foi feita uma regressão logística buscando identificar o que levaram 26,29\% dos respondentes se comportarem tal como o propugnado pela hipótese 2.Assim sendo, a variável explicada do modelo é uma dummy que recebe 1 se o indivíduo respondeu conforme a hipótese 2 e 0 caso contrário.

Com isso, foi feita uma regressão logística para investigar o que levava alguns indivíduos a responder de acordo com o efeito reflexão. O conjunto de variáveis explicativas do segundo modelo foi: 


\begin{tabular}{|c|c|c|}
\hline $\begin{array}{l}\text { Conjunto de Variáveis Explicativas - Regressão } \\
\text { Logística - Hip. } 2 \text { (efeito reflexão)- FEA/USP }\end{array}$ & Categorias da Variável ou Escala de Medida & Categoria de Referência \\
\hline Gênero & Feminino ou Masculino & Feminino \\
\hline Estado Civil & $\begin{array}{l}\text { Solteiro(a), Casado(a), Divorciado(a) ou } \\
\text { Viúvo(a) }\end{array}$ & Casado \\
\hline Idade & Dado em anos & \\
\hline \multicolumn{3}{|l|}{ Número de Filhos } \\
\hline Curso & $\begin{array}{l}\text { Ciências Contábeis, Ciências Econômicas, } \\
\text { Ciências Atuariais ou Outros }\end{array}$ & Outros \\
\hline Período do Curso & Diurno ou Noturno & Diurno \\
\hline Ano no Curso & Dado em anos & \\
\hline Trabalha ou Estagia & Sim ou Não & Não \\
\hline Há Quanto Tempo Trabalha & Dado em anos & \\
\hline Participou ou Participa de Iniciação Científica & Sim ou Não & Não \\
\hline Possui Outra Formação & Sim ou Não & Não \\
\hline Respondeu de acordo com a hipótese 1 & Sim ou Não & Não \\
\hline Respondeu de acordo com a hipótese 3 & Sim ou Não & Não \\
\hline Respondeu de acordo com a hipótese 6 & Sim ou Não & Não \\
\hline Respondeu de acordo com a hipótese 7 & Sim ou Não & Não \\
\hline Respondeu de acordo com a hipótese 9 & Sim ou Não & Não \\
\hline Respondeu de acordo com a hipótese 10 & Sim ou Não & Não \\
\hline
\end{tabular}

Quadro 4 - Conjunto de Variáveis Explicativas - Regressão Logística - Hip. 2 (efeito reflexão) FEA/USP

Logo, obteve-se o seguinte modelo:

Tabela 5 -Resultado da Regressão Logística - Hip. 2 (efeito reflexão) - FEA/USP

\begin{tabular}{|l|c|c|c|c|c|}
\hline & $\begin{array}{c}\text { Coeficiente } \\
\text { estimado }\end{array}$ & Erro Padrão & $\mathrm{z}$ & $P$-value & $\begin{array}{c}\text { Intervalo de Confiança - } \\
95 \%\end{array}$ \\
\hline Hipótese 10-Sim** & 0,6781453 & 0,3385213 & 2,00 & 0,045 & {$[0,146557 ; 1,341635]$} \\
\hline Trabalha ** & $-0,7058725$ & 0,3427909 & $-2,06$ & 0,039 & {$[-1,37773 ;-0,0340146]$} \\
\hline Constante** & $-0,5993006$ & 0,2880418 & $-2,08$ & 0,037 & {$[-1,163852 ;-0,0347491]$} \\
\hline Log likelihood-101,9915 & & & \\
LR chi2 (2) & & & \\
Prob> chi2 & 0,65 & & \\
Pseudo R ${ }^{2}$ & 0,0132 \\
Área Embaixo ROC & 0,6281 & & \\
* Significante pelo menos a 10\% & & \\
** Significante pelo menos a 5\% \\
*** Significante pelo menos a 1\%
\end{tabular}

Calculando a Odds Ratio para as variáveis explicativas, encontra-se que:

$$
\begin{aligned}
& e^{0,6781453}=1,97022 \\
& e^{-0,7058725}=0,4936777
\end{aligned}
$$


Analisando os achados acima transcritos, nota-se uma surpresa. Estudantes que responderam de acordo com o proposto pela hipótese 10, isto é, não conseguiram ver o efeito de regressão à média, possuem uma chance 97,02\% maior de também responderem de acordo com o proposto pela hipótese 2 em relação aos que perceberam o efeito de regressão à média.

Analogamente, este modelo também revela que para os indivíduos que trabalham ou fazem estágio, a chance deles arriscarem diante de uma perda certa é 50,63\% menor quando comparados aos que não trabalham e nem estagiam. Esse resultado pode não surpreender se for conjecturado que o indivíduo que já trabalha não é sustentado por outros membros familiares, o que o faria temer uma postura mais arriscada.

É importante salientar que todas essas análises de Odds Ratio são ceteris paribus e consideram todo o vetor de variáveis conjuntamente.

Enquanto as hipóteses 1 e 2 discorriam sobre o comportamento dos respondentes no tocante aos efeitos certeza e reflexão, a hipótese 3 testou se os indivíduos sofriam do efeito isolamento, isto é, se eles analisavam o par de decisões isoladamente ao invés de um conjunto.

Do conjunto de 369 respondentes, 205 (55,56\%) não responderam considerando o par de decisões conjuntamente, isto é, estes indivíduos não responderam de acordo com o cenário que trazia maior esperança matemática de retorno.

De modo análogo às demais hipóteses, foram feitos testes de hipóteses apropriados para $\mathrm{p}_{0}=$ 0,5 e $\mathrm{p}_{0}=0,75$. Para as hipóteses alternativas $\mathrm{p}_{0}>0,5$ e $\mathrm{p}_{0}>0,75$, os $p$-values obtidos foram respectivamente de 0,0164 e 1,0000. Assim sendo, para um nível de confiança de 95\%, há indícios de que a verdadeira proporção de alunos da FEA/USP que estão sujeitos ao efeito isolamento é maior do que 50\%, mas menor do que 75\%. Logo, a hipótese 3 dessa tese não pode ser rejeitada.

Assim como nas hipóteses 1 e 2, também foi feita uma regressão logística buscando identificar o que levaram $55,56 \%$ dos respondentes se comportarem tal como o propugnado 
pela hipótese 2.Assim sendo, a variável explicada do modelo é uma dummy que recebe 1 se o indivíduo respondeu conforme a hipótese 3 e 0 caso contrário.

Com isso, foi feita uma regressão logística para identificar o que levava alguns respondentes a sofrerem o efeito isolamento. O conjunto de variáveis explicativas do terceiro modelo foi:

\begin{tabular}{|l|l|l|}
\hline $\begin{array}{l}\text { Conjunto de Variáveis Explicativas - Regressão } \\
\text { Logística (efeito isolamento) - Hip. 3-FEA/USP }\end{array}$ & Categorias da Variável ou Escala de Medida & Categoria de Referência \\
\hline Gênero & Feminino ou Masculino & Feminino \\
\hline Estado Civil & $\begin{array}{l}\text { Solteiro(a), Casado(a), Divorciado(a) ou } \\
\text { Viúvo(a) }\end{array}$ & Casado \\
\hline Idade & Dado em anos & \\
\hline Número de Filhos & & \\
\hline Curso & $\begin{array}{l}\text { Ciências Contábeis, Ciências Econômicas, } \\
\text { Ciências Atuariais ou Outros }\end{array}$ & Outros \\
\hline Período do Curso & Diurno ou Noturno & Diurno \\
\hline Ano no Curso & Dado em anos & \\
\hline Trabalha ou Estagia & Sim ou Não & Não \\
\hline Há Quanto Tempo Trabalha & Dado em anos & Não \\
\hline Participou ou Participa de Iniciação Científica & Sim ou Não & Não \\
\hline Possui Outra Formação & Sim ou Não & Não \\
\hline Respondeu de acordo com a hipótese 6 & Sim ou Não & Não \\
\hline Respondeu de acordo com a hipótese 7 & Sim ou Não & Não \\
\hline Respondeu de acordo com a hipótese 9 & Sim ou Não & Não \\
\hline Respondeu de acordo com a hipótese 10 & Sim ou Não & \\
\hline
\end{tabular}

Quadro 5 - Conjunto de Variáveis Explicativas - Regressão Logística - Hip. 3 (efeito isolamento) - FEA/USP

Vale a pena observar que a hipótese 3 (efeito isolamento) é função das hipóteses 1 (efeito certeza) e 2 (efeito reflexão), isto implica em dizer que a variável dependente do modelo não pode incluir as outras duas como explicativas. 
Tabela 6 -Resultado da Regressão Logística - Hip. 3 (efeito isolamento) - FEA/USP

\begin{tabular}{|c|c|c|c|c|c|}
\hline & $\begin{array}{l}\text { Coeficiente } \\
\text { estimado }\end{array}$ & Erro Padrão & $\mathrm{z}$ & $P$-value & $\begin{array}{c}\text { Intervalo de Confiança- } \\
95 \%\end{array}$ \\
\hline Constante** & 0,2178665 & 0,1089493 & 2,00 & 0,046 & {$[0,0043298 ; 0,4314032]$} \\
\hline \multicolumn{6}{|c|}{ Log likelihood-234,3519 } \\
\hline LR chi2 $(0)$ & 0,00 & & & & \\
\hline \multicolumn{6}{|l|}{ Prob $>$ chi 2} \\
\hline Pseudo $\mathrm{R}^{2}$ & 0,000 & & & & \\
\hline Área Embaixo ROC & 0,5000 & & & & \\
\hline \multicolumn{6}{|c|}{ * Significante pelo menos a $10 \%$} \\
\hline \multicolumn{6}{|c|}{$* *$ Significante pelo menos a $5 \%$} \\
\hline *** Significante pelc & os a $1 \%$ & & & & \\
\hline
\end{tabular}

Como se verifica, nenhuma variável explicativa foi estatisticamente significativa, o que implica em dizer que não há um perfil em específico que leve os sujeitos a sofrerem o efeito certeza, ou seja, esse vetor de variáveis explicativas foi incapaz de descrever o evento. Dessa maneira, concluí-se de que o mesmo possa ser universal dentre o universo de alunos da FEA/USP.

Mais do que a discussão propriamente dita sobre o perfil dos respondentes, a não rejeição da hipótese 3 para os alunos da FEA/USP sugere um aspecto intrigante para os órgãos criadores dos procedimentos técnicos a serem aplicados, tais como o IASB. Se os indivíduos lerem cada nota explicativa de uma empresa de modo separado, eles podem estar sujeitos ao efeito isolamento, o que implicaria de que a forma como as informações são apresentadas (em termos de notas explicativas separadas), pode ensejar uma visão fragmentada das informações financeiras por parte dos seus usuários.

\subsubsection{Questão 2 - Estudantes da Faculdade de Economia, Administração e Contabilidade da Universidade de São Paulo}

Tendo em vista o abordado no capítulo de metodologia, a questão 2 buscava verificar se a heurística da ancoragem influenciava a decisão dos respondentes (hipótese 4). Para tanto, a questão 2 havia sido dividida em 2 versões, uma ancorada na perda e outra na não perda. Logo, o objetivo foi investigar se o framing era estatisticamente significativo, isto é, se a proporção de indivíduos que recomendavam a compra da ação era estatisticamente maior quando a nota explicativa estava ancorada na não perda. 
Dos 369 respondentes, 250 indivíduos responderam a questão ancorada na perda, enquanto que 119 responderam na ancorada na não perda. A diferença entre o número de respondentes em ambas as versões se deve a um fator de conveniência. Foram distribuídos vários questionários, de modo que existiram mais retornos na primeira versão. Entretanto, esse fato não prejudica em nada os achados obtidos, na medida em que os testes de hipóteses comparam as proporções observadas e não os valores absolutos.

Na versão ancorada na perda, 188 respondentes $(75,20 \%)$ recomendaram a compra da ação, ao passo de que na não perda, 83 indivíduos $(69,75 \%)$ recomendaram a compra. Os achados são conflitantes, na medida em que parecem levantar a ideia de que a proporção de respondentes que recomendam a compra é maior em uma situação que está claramente ancorada na perda.

Entretanto, a aplicação do teste de hipóteses que busca verificar se existe diferença nas proporções observadas entre as versões, revela que a um nível de significância de $5 \%$, não existem indícios de que haja diferenças entre uma abstrata população de alunos que responderia a versão ancorada na perda e uma outra não ancorada na perda. Assumindo que a hipótese nula do teste seja de que a diferença é igual a 0 , para a hipótese alternativa de que a diferença é diferente de 0 , obteve-se um p-value de 0,2677 , o que realça o discorrido nesse excerto.

Adicionalmente, buscou-se verificar efetivamente quais variáveis poderiam explicar a recomendação da compra da ação através de uma regressão logística. O conjunto de variáveis explicativas do quarto modelo foi: 


\begin{tabular}{|l|l|l|}
\hline $\begin{array}{l}\text { Conjunto de Variáveis Explicativas - Regressão } \\
\text { Logística (efeito ancoragem) - Hip.4-FEA/USP }\end{array}$ & Categorias da Variável ou Escala de Medida & Categoria de Referência \\
\hline Gênero & Feminino ou Masculino & Feminino \\
\hline Estado Civil & $\begin{array}{l}\text { Solteiro(a), Casado(a), Divorciado(a) ou } \\
\text { Viúvo(a) }\end{array}$ & Casado \\
\hline Idade & Dado em anos & \\
\hline Número de Filhos & & \\
\hline Curso & $\begin{array}{l}\text { Ciências Contábeis, Ciências Econômicas, } \\
\text { Ciências Atuariais ou Outros }\end{array}$ & Outros \\
\hline Período do Curso & Diurno ou Noturno & Diurno \\
\hline Ano no Curso & Dado em anos & \\
\hline Trabalha ou Estagia & Sim ou Não & Não \\
\hline Há Quanto Tempo Trabalha & Dado em anos & \\
\hline Participou ou Participa de Iniciacão Científica & Sim ou Não & Não \\
\hline Possui Outra Formação & Sim ou Não & Não \\
\hline Versão da Questão 2 & Ancorada na Perda ou na Não Perda & Ancorada na Perda \\
\hline Respondeu de acordo com a hipótese 1 & Sim ou Não & Não \\
\hline Respondeu de acordo com a hipótese 2 & Sim ou Não & Não \\
\hline Respondeu de acordo com a hipótese 3 & Sim ou Não & Não \\
\hline Respondeu de acordo com a hipótese 6 & Sim ou Não & Não \\
\hline Respondeu de acordo com a hipótese 7 & Sim ou Não & Não \\
\hline Respondeu de acordo com a hipótese 9 & Sim ou Não \\
\hline Respondeu de acordo com a hipótese 10 & Sim ou Não & \\
\hline
\end{tabular}

Quadro 6 - Conjunto de Variáveis Explicativas - Regressão Logística - Hip. 4 (efeito ancoragem) - FEA/USP

O resultado do modelo é apresentado abaixo:

Tabela 7 -Resultado da Regressão Logística - Hip. 4 (efeito ancoragem) - FEA/USP

\begin{tabular}{|c|c|c|c|c|c|}
\hline & $\begin{array}{l}\text { Coeficiente } \\
\text { estimado }\end{array}$ & Erro Padrão & $\mathrm{Z}$ & P-value & $\begin{array}{c}\text { Intervalo de Confiança - } \\
95 \%\end{array}$ \\
\hline $\operatorname{Idade}^{* * *}$ & $-0,0820177$ & 0,0239667 & $-3,42$ & 0,001 & {$[-0,1289916 ;-0,0350438]$} \\
\hline Constante ${ }^{* * *}$ & 2,975028 & 0,5702416 & 5,22 & 0,000 & {$[1,857375 ; 4,092681]$} \\
\hline \multicolumn{6}{|c|}{ Log likelihood-184,73326 } \\
\hline \multicolumn{6}{|l|}{ LR chi2 (1)12,35 } \\
\hline Prob $>$ chi 2 & 0,0004 & & & & \\
\hline Pseudo $\mathrm{R}^{2}$ & 0,0323 & & & & \\
\hline Área Embaixo ROC & 0,5881 & & & & \\
\hline \multicolumn{6}{|c|}{ * Significante pelo menos a $10 \%$} \\
\hline \multicolumn{6}{|c|}{ ** Significante pelo menos a $5 \%$} \\
\hline \multicolumn{6}{|c|}{$* * *$ Significante pelo menos a $1 \%$} \\
\hline
\end{tabular}

Conforme o teste de hipóteses relata, a versão da questão não explica como os indivíduos tomam suas decisões, ou seja, para um mesmo conteúdo informacional, somente a ancoragem na perda ou na não perda não foram suficientes para discriminar adequadamente o evento. 
A $95 \%$ de confiança, somente a variável idade se mostrou estatisticamente significativa. Calculando a Odds Ratio para mesma, encontra-se que:

$e^{-0,0820177}=0,9212557$

Logo, para a população de alunos da FEA/USP, conclúí-se que ceteris paribus, e na presença das demais variáveis, 1 ano a mais de idade, faz com que a chance de recomendar a compra da ação seja 7,87\% menor. Isso implica em dizer que os estudantes com maior idade tendem a ser mais conservadoras, o que não se trata de uma surpresa.

\subsubsection{Questão 3 - Estudantes da Faculdade de Economia, Administração e Contabilidade da Universidade de São Paulo}

Conforme discorrido no capítulo 3, a hipótese 5 também buscava observar se o efeito de formulação influenciava o processo decisório em um ambiente que usa informações contábeis.

A mesma também possuía duas versões com o mesmo conteúdo informacional, sendo que uma apresentava o empréstimo em termos de valores brutos, ao passo em que a outra o mostrava em termos de alavancagem do patrimônio líquido.

Do total de 369 respondentes, 250 responderam a versão da questão que apresentava o valor do empréstimo em termos brutos, ao passo que 119 responderam a versão em que o mesmo era apresentado em termos de alavancagem do patrimônio líquido.

Dos 250 indivíduos que fizeram a primeira versão, somente $59(23,60 \%)$ aprovou o empréstimo dado a situação financeira da empresa. Por sua vez, na outra versão, foram cerca de 30 indivíduos $(25,21 \%)$. Esse resultado, em primeira instância, pode surpreender, pois sugere que a proporção de respondentes que aprovaram o empréstimo na versão em termos de alavancagem do patrimônio líquido é ligeiramente maior. Nessa versão, era escrito explicitamente que o financiamento representava 5 vezes o patrimônio líquido, o que poderia sugerir que os indivíduos ficariam mais receosos. 
Entretanto, a aplicação do teste de hipóteses de diferença de proporções, revela que a um nível de significância de 5\%, não existem indícios de que haja diferenças entre uma abstrata população de alunos da FEA/USP que responderia a versão formulada em termos de valores brutos e uma em termos de alavancagem do patrimônio líquido. Assumindo que a hipótese nula do teste seja de que a diferença é igual a 0 , para a hipótese alternativa de que a diferença é diferente de 0 , obteve-se um p-value de 0,7354 , o que realça o discorrido nesse excerto.

Assim sendo, não existem indícios de que o efeito de formulação seja observado para os alunos de ciências contábeis, o que pode fortalecer a ideia de que a essência econômica prevaleça sobre a forma.

Não obstante, procurou-se verificar efetivamente quais variáveis poderiam explicar a aprovação do empréstimo, mesmo em um cenário no qual a empresa poderia apresentar dificuldades em honrar com seu compromisso. Com isso, foi feita uma regressão logística com o seguinte conjunto de variáveis explicativas: 


\begin{tabular}{|c|c|c|}
\hline $\begin{array}{c}\text { Conjunto de Variáveis Explicativas - Regressão } \\
\text { Logística (números brutos x números relativos) - } \\
\text { Hip. 5- FEA/USP }\end{array}$ & Categorias da Variável ou Escala de Medida & Categoria de Referência \\
\hline Gênero & Feminino ou Masculino & Feminino \\
\hline Estado Civil & $\begin{array}{llll}\text { Solteiro(a), Casado(a), } & \text { Divorciado(a) } & \text { ou } \\
\text { Viúvo(a) } & & \\
\end{array}$ & Casado \\
\hline Idade & Dado em anos & \\
\hline \multicolumn{3}{|l|}{ Número de Filhos } \\
\hline Curso & $\begin{array}{l}\text { Ciências Contábeis, Ciências Econômicas, } \\
\text { Ciências Atuariais ou Outros }\end{array}$ & Outros \\
\hline Período do Curso & Diurno ou Noturno & Diurno \\
\hline Ano no Curso & Dado em anos & \\
\hline Trabalha ou Estagia & Sim ou Não & Não \\
\hline Há Quanto Tempo Trabalha & Dado em anos & \\
\hline Participou ou Participa de Iniciação Científica & Sim ou Não & Não \\
\hline Possui Outra Formação & Sim ou Não & Não \\
\hline Versão da Questão 3 & 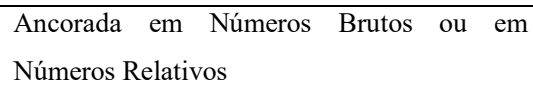 & Ancorada em Números Brutos \\
\hline Respondeu de acordo com a hipótese 1 & Sim ou Não & Não \\
\hline Respondeu de acordo com a hipótese 2 & Sim ou Não & Não \\
\hline Respondeu de acordo com a hipótese 3 & Sim ou Não & Não \\
\hline Respondeu de acordo com a hipótese 6 & Sim ou Não & Não \\
\hline Respondeu de acordo com a hipótese 7 & Sim ou Não & Não \\
\hline Respondeu de acordo com a hipótese 9 & Sim ou Não & Não \\
\hline Respondeu de acordo com a hipótese 10 & Sim ou Não & Não \\
\hline
\end{tabular}

\section{Quadro 7 - Conjunto de Variáveis Explicativas - Regressão Logística - Hip. 5 (números brutos x} números relativos) - FEA/USP

O resultado do modelo é apresentado abaixo:

Tabela 8 - Resultado da Regressão Logística - Hip. 5 (números brutos x números relativos) - FEA/USP

\begin{tabular}{|c|c|c|c|c|c|}
\hline & $\begin{array}{l}\text { Coeficiente } \\
\text { estimado }\end{array}$ & Erro Padrão & $\mathrm{z}$ & $P$-value & $\begin{array}{c}\text { Intervalo de Confiança - } \\
95 \%\end{array}$ \\
\hline $\begin{array}{l}\text { Ciências } \\
\text { Contábeis*** }\end{array}$ & $-0,9179688$ & 0,3194544 & $-2,87$ & 0,004 & {$[-1,544088 ;-0,2918497]$} \\
\hline Noturno*** & $-0,840326$ & 0,3203356 & $-2,62$ & 0,009 & {$[-1,468172 ;-0,2124798]$} \\
\hline Constante & $-0,0258518$ & 0,3815272 & $-0,07$ & 0,946 & {$[-0,7736314 ; 0,7219278]$} \\
\hline \multicolumn{6}{|c|}{ Log likelihood-177,46523 } \\
\hline LR chi2 (2) & 10,77 & & & & \\
\hline Prob $>$ chi 2 & 0,0046 & & & & \\
\hline Pseudo $\mathrm{R}^{2}$ & 0,0295 & & & & \\
\hline Área Embaixo ROC & 0,6057 & & & & \\
\hline \multicolumn{6}{|c|}{ * Significante pelo menos a $10 \%$} \\
\hline \multicolumn{6}{|c|}{ ** Significante pelo menos a $5 \%$} \\
\hline \multicolumn{6}{|c|}{ *** Significante pelo menos a $1 \%$} \\
\hline
\end{tabular}


Como já era de se esperar (em virtude do teste de hipóteses), a versão da questão não explica como os indivíduos tomam suas decisões de aprovação dos empréstimos, ou seja, para um mesmo conteúdo informacional, somente a ancoragem no número bruto ou na alavancagem do patrimônio líquido não foram suficientes para discriminar adequadamente o evento.

A 5\% de significância, as variáveis que dizem respeito ao curso em que o respondente está fazendo e o período foram estatisticamente significativas. Com isso, calculando a Odds Ratio de ambas as variáveis, temos que:

$$
\begin{aligned}
& e^{-0,9179688}=0,3993293 \\
& e^{-0,840326}=0,4315698
\end{aligned}
$$

Logo, para a população de alunos da FEA/USP, conclui-se que ceteris paribus, e na presença das demais variáveis, um aluno do curso de ciências contábeis possui uma chance $60,07 \%$ menor de aprovar o empréstimo em relação aos demais cursos. Esse achado denota que o ensino formal em ciências contábeis ajuda a reduzir a probabilidade de um indivíduo responder de modo enviesado, tal como o propugnado pela Prospect Theory.

Raciocinando analogamente, um aluno do período noturno possui uma chance $56,84 \%$ menor de aprovar o empréstimo, quando comparado ao aluno do período diurno, ceteris paribus e na presença das demais variáveis. Pode-se conjecturar que isso possa ser devido a uma eventual postura mais conservadora por parte desses estudantes.

\subsubsection{Questão 4 - Estudantes da Faculdade de Economia, Administração e Contabilidade da Universidade de São Paulo}

Tal como discutido anteriormente, a hipótese 6 buscava verificar se os respondentes sofriam os efeitos da correlação ilusória ou se tinham problemas em identificar o sentido estatístico por detrás da correlação.

Na questão, indagava-se indiretamente se um indivíduo recomendaria a compra de uma ação de uma empresa do mesmo grupo (coligada ou controlada) como forma de garantir o lucro do próximo período, sendo assim uma correlação ilusória. 
No universo dos 369 respondentes, 243 (65,85\%) afirmaram que recomendariam a compra de uma ação do mesmo grupo como forma de garantir o lucro do próximo período. Esse fato, por si só, já sinaliza de que há fortes indícios de que os alunos da FEA/USP estão, de modo geral, sofrendo os efeitos do viés de correlação ilusória, mesmo para alunos do curso de Ciências Contábeis, que teriam maior expertise para interpretar a Demonstração de Resultados providenciada.

De fato, fazendo o teste de hipóteses apropriado para $\mathrm{p}_{0}=0,5$ e $\mathrm{p}_{0}=0,75$, testou-se se a proporção de indivíduos que assinalaram de acordo com a hipótese 6 era estatisticamente igual a $50 \%$ e $75 \%$ respectivamente. Para as hipóteses alternativas $\mathrm{p}_{0}>0,5$ e $\mathrm{p}_{0}>0,75$, os $p$ values de ambos os testes foram de 0,0000 e 1,0000 respectivamente. Logo, a verdadeira proporção de alunos da FEA/USP que recomendariam a compra da ação do mesmo grupo como forma de garantir lucros (hedge) é superior a 50\%, mas inferior a $75 \%$, considerando um nível de significância de 5\%.

Esse é um indício importante que mesmo a educação formal de alunos de uma das melhores escolas de negócio do Brasil não os exime de riscos oriundos da ilusão de validade proporcionada pela correlação ilusória. A questão exigia simples conhecimentos de finanças (noção mínima de diversificação de riscos), mas isso não impediu que a simples linha do método por equivalência patrimonial fizesse com que todo o raciocínio dos respondentes não seguisse a essência econômica de uma decisão mais acurada com os procedimentos teóricos normalmente observados.

Tal como nas demais hipóteses, uma regressão logística foi feita buscando identificar o que levaram $65,85 \%$ dos respondentes não verificassem a correlação ilusória. Assim sendo, a variável explicada do modelo é uma dummy que recebe 1 se o indivíduo respondeu conforme a hipótese 6 e 0 caso contrário.

O conjunto de variáveis explicativas deste modelo foi: 


\begin{tabular}{|l|l|l|}
\hline $\begin{array}{c}\text { Conjunto de Variáveis Explicativas - Regressão } \\
\text { Logística - Hip. 6 (correlação ilusória)- FEA/USP }\end{array}$ & Categorias da Variável ou Escala de Medida & Categoria de Referência \\
\hline Gênero & Feminino ou Masculino & Feminino \\
\hline Estado Civil & $\begin{array}{l}\text { Solteiro(a), Casado(a), Divorciado(a) ou } \\
\text { Viúvo(a) }\end{array}$ & Casado \\
\hline Idade & Dado em anos & \\
\hline Número de Filhos & & \\
\hline Curso & Ciências Contábeis, Ciências Econômicas, & Outros \\
\hline Período do Curso & Ciências Atuariais ou Outros & \\
\hline Ano no Curso & Diurno ou Noturno & Diurno \\
\hline Trabalha ou Estagia & Dado em anos & Não \\
\hline Há Quanto Tempo Trabalha & Sim ou Não & \\
\hline Participou ou Participa de Iniciação Científica & Dado em anos & Não \\
\hline Possui Outra Formação & Sim ou Não & Não \\
\hline Respondeu de acordo com a hipótese 1 & Sim ou Não & Não \\
\hline Respondeu de acordo com a hipótese 2 & Sim ou Não & Não \\
\hline Respondeu de acordo com a hipótese 3 & Sim ou Não & Não \\
\hline Respondeu de acordo com a hipótese 7 & Sim ou Não & Não \\
\hline Respondeu de acordo com a hipótese 9 & Sim ou Não & Não \\
\hline Respondeu de acordo com a hipótese 10 & Sim ou Não \\
\hline
\end{tabular}

Quadro 8 - Conjunto de Variáveis Explicativas - Regressão Logística - Hip. 6 (correlação ilusória) - FEA/USP

Logo, obteve-se o seguinte modelo:

Tabela 9 - Resultado da Regressão Logística - Hip. 6 (correlação ilusória) - FEA/USP

\begin{tabular}{|c|c|c|c|c|c|}
\hline & $\begin{array}{l}\text { Coeficiente } \\
\text { estimado }\end{array}$ & Erro Padrão & $\mathrm{z}$ & $P$-value & $\begin{array}{c}\text { Intervalo de Confiança - } \\
95 \%\end{array}$ \\
\hline Constante*** & 0,6405034 & 0,1142432 & 5,61 & 0,000 & {$[0,4165909 ; 0,864416]$} \\
\hline \multicolumn{6}{|c|}{ Log likelihood-218,44531 } \\
\hline LR chi2 $(0)$ & 0,00 & & & & \\
\hline \multicolumn{6}{|l|}{ Prob $>$ chi 2} \\
\hline Pseudo $\mathrm{R}^{2}$ & 0,000 & & & & \\
\hline Área Embaixo ROC & 0,5000 & & & & \\
\hline \multicolumn{6}{|c|}{ * Significante pelo menos a $10 \%$} \\
\hline \multicolumn{6}{|c|}{$* *$ Significante pelo menos a $5 \%$} \\
\hline$* * *$ Significante pelc & $1 \%$ & & & & \\
\hline
\end{tabular}

Nenhuma variável demonstrou ser estatisticamente significativa a um nível de confiança de $95 \%$, o que sugere que o efeito de correlação ilusória não depende do perfil social e acadêmico dos respondentes, conferindo-lhe um caráter mais holístico dentre os alunos da FEA/USP. 


\subsubsection{Questão 5 - Estudantes da Faculdade de Economia, Administração e Contabilidade da Universidade de São Paulo}

Tal como discutido anteriormente, a questão 5 envolvia diretamente a hipótese 7 dessa tese. A mesma estava intimamente associada à facilidade com que os indivíduos tinham de recuperar eventos pertencentes a uma determinada classe, isto é, ela testava como a heurística da disponibilidade influenciava a recuperabilidade das ocorrências.

Nela, indagava-se se o respondente compraria uma ação de uma empresa que tinha passado recentemente por uma crise de corrupção. Apesar de a nota explicativa atentar que a empresa já tinha tomado as boas práticas de governança e gerenciamento de riscos, $242(65,58 \%)$ indivíduos responderam que não comprariam a ação dessa empresa.

Esse fato, por si só, já se consubstancia como um indicativo de que a hipótese 7 dessa tese não pode ser refutada. Entretanto, conforme o capítulo de metodologia expôs, testes de hipóteses de proporção foram feitos. Aplicando o teste de hipóteses apropriado para $\mathrm{p}_{0}=0,5$ e $\mathrm{p}_{0}=$ 0,75 , testou-se se a proporção de indivíduos que assinalaram de acordo com a hipótese 7 era estatisticamente igual a $50 \%$ e $75 \%$ respectivamente. Para as hipóteses alternativas $\mathrm{p}_{0}>0,5 \mathrm{e}$ $\mathrm{p}_{0}>0,75$, os $p$-values de ambos os testes foram de 0,0000 e 1,0000 respectivamente. Logo, tal como no par de teste de hipóteses atinente à questão 4, a verdadeira proporção de alunos da FEA/USP que comprariam essa ação é superior a 50\%, mas inferior a $75 \%$, considerando um nível de significância de 5\%.

Assim sendo, há uma sinalização de que não há como rejeitar que o efeito de disponibilidade atue sobre o processo decisório dos agentes. Isso pode implicar que em determinados cenários, a informação contábil possa ficar relegada a um segundo plano, mesmo que ela seja completamente acurada. Nesse cenário, a forma com que a informação foi transmitida não seria tão impactante. Entretanto, de modo complementar, a essência econômica também não estaria sendo respeitada, dado que mesmo se os demonstrativos financeiros fossem auditados, muitas pessoas estariam agindo com base em uma memória ruim heuristicamente disponível para tomar sua decisão. 
Uma regressão logística também foi feita para tentar identificar se existia alguma variável dentre o perfil acadêmico e social dos alunos que poderia explicar esse comportamento. Com isso,o conjunto de variáveis explicativas deste modelo foi:

\begin{tabular}{|l|l|l|}
\hline $\begin{array}{c}\text { Conjunto de Variáveis Explicativas - Regressão } \\
\text { Logística - Hip. 7 (heurística da disponibilidade)- } \\
\text { FEA/USP }\end{array}$ & Categorias da Variável ou Escala de Medida & Categoria de Referência \\
\hline Gênero & Feminino ou Masculino & Feminino \\
\hline Estado Civil & $\begin{array}{l}\text { Solteiro(a), Casado(a), Divorciado(a) ou } \\
\text { Viúvo(a) }\end{array}$ & Casado \\
\hline Idade & Dado em anos & \\
\hline Número de Filhos & & \\
\hline Curso & Ciências Contábeis, Ciências Econômicas, & Outros \\
\hline Período do Curso & Ciências Atuariais ou Outros & \\
\hline Ano no Curso & Diurno ou Noturno & Diurno \\
\hline Trabalha ou Estagia & Dado em anos & Não \\
\hline Há Quanto Tempo Trabalha & Sim ou Não & \\
\hline Participou ou Participa de Iniciação Científica & Dado em anos & Sim ou Não \\
\hline Possui Outra Formação & Sim ou Não & Não \\
\hline Respondeu de acordo com a hipótese 1 & Sim ou Não & Não \\
\hline Respondeu de acordo com a hipótese 2 & Sim ou Não & Não \\
\hline Respondeu de acordo com a hipótese 3 & Sim ou Não & Não \\
\hline Respondeu de acordo com a hipótese 6 & Sim ou Não & Não \\
\hline Respondeu de acordo com a hipótese 9 & Sim ou Não \\
\hline Respondeu de acordo com a hipótese 10 & Sim ou Não & \\
\hline
\end{tabular}

Quadro 9 - Conjunto de Variáveis Explicativas - Regressão Logística - Hip. 7 (heurística da disponibilidade) - FEA/USP

Logo, obteve-se o seguinte modelo:

Tabela 10 - Resultado da Regressão Logística - Hip. 7 (heurística da disponibilidade) - FEA/USP

\begin{tabular}{|l|c|c|c|c|c|}
\hline & $\begin{array}{c}\text { Coeficiente } \\
\text { estimado }\end{array}$ & Erro Padrão & $\mathrm{z}$ & P-value & $\begin{array}{c}\text { Intervalo de Confiança - } \\
95 \%\end{array}$ \\
\hline Idade** & 0,0650689 & 0,0266478 & 2,44 & 0,015 & {$[0,0128401 ; 0,1172977]$} \\
\hline Constante & $-0,8577762$ & 0,5956489 & $-1,44$ & 0,150 & {$[-2,025227 ; 0,3096743]$} \\
\hline Log likelihood-217,47919 & & & \\
LR chi2 (1) & & & \\
Prob> chi2 & 6,85 & & \\
Pseudo R ${ }^{2}$ & 0,0089 & & \\
Área Embaixo ROC & 0,0155 & & \\
* Significante pelo menos a 10\% & & \\
** Significante pelo menos a 5\% & & \\
*** Significante pelo menos a 1\% & & \\
\end{tabular}


A 5\% de significância, somente a variável idade se mostrou estatisticamente significativa. Com isso, calculando a Odds Ratio dela, temos que:

$e^{0,0650689}=1,06723$

Assim, ceteris paribus, e na presença das demais variáveis, 1 ano a mais de idade leva a uma chance $6,72 \%$ maior de se decidir utilizando a heurística da disponibilidade. Esse é um achado importante, pois revela que no universo de alunos da FEA/USP, pessoas mais velhas tendem a evocar mais facilmente memórias desagradáveis.

\subsubsection{Questão 6 - Estudantes da Faculdade de Economia, Administração e Contabilidade da Universidade de São Paulo}

Assim como as questões 2 e 3, a questão 6 (envolvia a hipótese 8) também possuía duas versões. $\mathrm{O}$ objetivo da mesma foi verificar se existia algum tipo de ancoragem às palavras lucro e prejuízo. Em ambos os cenários, o preço de uma dada ação tinha se comportado de modo estritamente idêntico. Contudo, na primeira, a empresa havia apresentado um lucro abaixo do esperado, enquanto na segunda, a queda no preço se dava devido a um prejuízo devido a fatores exógenos, isto é, o prejuízo não era decorrente de uma má administração.

As estatísticas descritivas parecem sugerir que a amostra de estudantes da FEA/USP está mais preocupada com a variação do preço do mercado per si e não à ancoragem a termos como prejuízo e lucro.

$\mathrm{Na}$ primeira versão descrita anteriormente, de um total de 250 respondentes, 57,60\% ainda sim comprariam uma nova ação. Já na segunda versão, dos 119 respondentes, 58,82\% também comprariam, o que sugere que a hipótese 8 dessa tese pode ser refutada no universo dos alunos.

Esse achado é corroborado pelo teste de hipóteses de diferença de proporções. Este revela que a um nível de significância de 5\%, não existem indícios de que haja diferenças entre uma abstrata população de alunos da FEA/USP que responderia a versão onde há lucro e na que há prejuízo. Assumindo que a hipótese nula do teste seja de que a diferença é igual a 0 , para a 
hipótese alternativa de que a diferença é diferente de 0 , obteve-se um p-value de 0,8239 , o que explica o comentado acima.

Diante desse cenário, percebe-se que as três hipóteses $(4,5$ e 8$)$ que buscavam verificar a ocorrência de alguma ancoragem foram refutadas perante os alunos da FEA/USP. A posteriori, é feito um quadro comparativo com as hipóteses que não foram refutadas pelos alunos e as que não foram refutadas pelos profissionais de uma grande instituição financeira, com as devidas conclusões.

Ainda assim, foi feita uma regressão logística para tentar capturar se existia algum outro fator social e acadêmico que explicasse os resultados obtidos. As variáveis explicativas foram:

\begin{tabular}{|l|l|l|}
\hline $\begin{array}{l}\text { Conjunto de Variáveis Explicativas - Regressão } \\
\text { Logística (lucro x prejuízo) - Hip. 8- FEA/USP }\end{array}$ & Categorias da Variável ou Escala de Medida & Categoria de Referência \\
\hline Gênero & Feminino ou Masculino & Feminino \\
\hline Estado Civil & $\begin{array}{l}\text { Solteiro(a), Casado(a), Divorciado(a) ou } \\
\text { Viúvo(a) }\end{array}$ & Casado \\
\hline Idade & Dado em anos & \\
\hline Número de Filhos & & \\
\hline Curso & $\begin{array}{l}\text { Ciências Contábeis, Ciências Econômicas, } \\
\text { Ciências Atuariais ou Outros }\end{array}$ & Outros \\
\hline Período do Curso & Diurno ou Noturno & Diurno \\
\hline Ano no Curso & Dado em anos & \\
\hline Trabalha ou Estagia & Sim ou Não & Não \\
\hline Há Quanto Tempo Trabalha & Dado em anos & \\
\hline Participou ou Participa de Iniciacão Científica & Sim ou Não & Não \\
\hline Possui Outra Formação & Sim ou Não & Não \\
\hline Versão do Questão 6 & Ancorada no Lucro ou no Prejuízo & Lucro \\
\hline Respondeu de acordo com a hipótese 1 & Sim ou Não & Não \\
\hline Respondeu de acordo com a hipótese 2 & Sim ou Não & Não \\
\hline Respondeu de acordo com a hipótese 3 & Sim ou Não & Não \\
\hline Respondeu de acordo com a hipótese 6 & Sim ou Não & Não \\
\hline Respondeu de acordo com a hipótese 7 & Sim ou Não & Não \\
\hline Respondeu de acordo com a hipótese 9 & Sim ou Não \\
\hline Respondeu de acordo com a hipótese 10 & Sim ou Não \\
\hline
\end{tabular}

Quadro 10 - Conjunto de Variáveis Explicativas - Regressão Logística - Hip. 8 (lucro x prejuízo) - FEA/USP

O modelo obtido foi: 
Tabela 11 - Resultado da Regressão Logística - Hip. 8 (lucro x prejuízo) - FEA/USP

\begin{tabular}{|c|c|c|c|c|c|}
\hline & $\begin{array}{l}\text { Coeficiente } \\
\text { estimado }\end{array}$ & Erro Padrão & $\mathrm{Z}$ & $P$-value & $\begin{array}{c}\text { Intervalo de Confiança - } \\
95 \%\end{array}$ \\
\hline Constante*** & 0,31527 & 0,1099775 & 2,87 & 0,004 & {$[0,0997181 ; 0,5308219]$} \\
\hline \multicolumn{6}{|c|}{ Log likelihood-230,81678 } \\
\hline LR chi2 $(0)$ & 0,00 & & & & \\
\hline \multicolumn{6}{|l|}{ Prob $>$ chi2 } \\
\hline Pseudo $\mathrm{R}^{2}$ & 0,000 & & & & \\
\hline Área Embaixo ROC & 0,5000 & & & & \\
\hline \multicolumn{6}{|c|}{ * Significante pelo menos a $10 \%$} \\
\hline \multicolumn{6}{|c|}{ ** Significante pelo menos a $5 \%$} \\
\hline$* * *$ Significante pelc & a $1 \%$ & & & & \\
\hline
\end{tabular}

Assim, nenhuma variável do modelo foi capaz de explicar com precisão o que motivou os agentes a dizer que comprariam uma ação dessa empresa.

\subsubsection{Questão 7 - Estudantes da Faculdade de Economia, Administração e Contabilidade da Universidade de São Paulo}

A questão 7 trazia a hipótese 9 dessa tese. Seu objetivo era verificar se os respondentes faziam uso da heurística da representatividade para tomar suas decisões, isto é, se eles avaliavam o quão próximo um fenômeno está de algo análogo.

Na referida questão, era dito explicitamente que os clientes devedores de um banco eram independentes entre si, sendo que cada um tinha uma probabilidade maior de $50 \%$ de aceitar renegociar sua dívida. Após essa observação, um excerto era criado, onde um cliente era equiparado a outro que não havia aceitado a renegociação da dívida por analogia de setor de negócios e situação financeira.

Apesar dos clientes serem independentes entre si, o simples uso da heurística da representatividade fez com que $253(68,56 \%)$ respondentes concluíssem que este novo cliente também não aceitaria a renegociação. Com isso, há um forte indicativo de que a hipótese 9 não pode ser refutada.

De fato, ao se aplicar o teste de hipóteses apropriado para $\mathrm{p}_{0}=0,5$ e $\mathrm{p}_{0}=0,75$, testou-se se a proporção de indivíduos que assinalaram de acordo com a hipótese 9 era estatisticamente igual a $50 \%$ e $75 \%$ respectivamente. Para as hipóteses alternativas $\mathrm{p}_{0}>0,5$ e $\mathrm{p}_{0}>0,75$, os $p$ - 
values de ambos os testes foram de 0,0000 e 0,9979 respectivamente. Assim, a verdadeira proporção de alunos da FEA/USP que usariam a heurística da representatividade é superior a $50 \%$, mas inferior a $75 \%$, considerando um nível de significância de 5\%.

Essa implicação é forte e relevante para a ciência contábil, pois pode indicar que apesar da essência econômica dizer o contrário, a equiparação por analogias é capaz de convencer os usuários das informações contábeis de similaridades entre alguns pontos, quando estes não são de fato parecidos.

Tentando investigar o que levou os alunos da FEA/USP a responderem tal como o propugnado acima, foi feita uma regressão logística com o seguinte conjunto de variáveis explicativas:

\begin{tabular}{|c|c|c|}
\hline $\begin{array}{c}\text { Conjunto de Variáveis Explicativas - Regressão } \\
\text { Logística - Hip. } 9 \text { (heurística da } \\
\text { representatividade)- FEA/USP }\end{array}$ & Categorias da Variável ou Escala de Medida & Categoria de Referência \\
\hline Gênero & Feminino ou Masculino & Feminino \\
\hline Estado Civil & $\begin{array}{l}\text { Solteiro(a), Casado(a), Divorciado(a) ou } \\
\text { Viúvo(a) }\end{array}$ & Casado \\
\hline Idade & Dado em anos & \\
\hline \multicolumn{3}{|l|}{ Número de Filhos } \\
\hline Curso & $\begin{array}{l}\text { Ciências Contábeis, Ciências Econômicas, } \\
\text { Ciências Atuariais ou Outros }\end{array}$ & Outros \\
\hline Período do Curso & Diurno ou Noturno & Diurno \\
\hline Ano no Curso & Dado em anos & \\
\hline Trabalha ou Estagia & Sim ou Não & Não \\
\hline Há Quanto Tempo Trabalha & Dado em anos & \\
\hline Participou ou Participa de Iniciação Científica & Sim ou Não & Não \\
\hline Possui Outra Formação & Sim ou Não & Não \\
\hline Respondeu de acordo com a hipótese 1 & Sim ou Não & Não \\
\hline Respondeu de acordo com a hipótese 2 & Sim ou Não & Não \\
\hline Respondeu de acordo com a hipótese 3 & Sim ou Não & Não \\
\hline Respondeu de acordo com a hipótese 6 & Sim ou Não & Não \\
\hline Respondeu de acordo com a hipótese 7 & Sim ou Não & Não \\
\hline Respondeu de acordo com a hipótese 10 & Sim ou Não & Não \\
\hline
\end{tabular}

Quadro 11 - Conjunto de Variáveis Explicativas - Regressão Logística - Hip. 9 (heurística da representatividade) - FEA/USP

O resultado do modelo é tal que: 
Tabela 12 - Resultado da Regressão Logística - Hip. 9 (heurística da representatividade) - FEA/USP

\begin{tabular}{|c|c|c|c|c|c|}
\hline & $\begin{array}{l}\text { Coeficiente } \\
\text { estimado }\end{array}$ & Erro Padrão & $\mathrm{z}$ & $P$-value & $\begin{array}{c}\text { Intervalo de Confiança - } \\
95 \%\end{array}$ \\
\hline Trabalha*** & $-0,6626478$ & 0,2353784 & $-2,82$ & 0,005 & {$[-1,123981 ;-0,2013146]$} \\
\hline Constante ${ }^{* * *}$ & 1,05694 & 0,1658323 & 6,37 & 0,000 & {$[0,7319142 ; 1,381965]$} \\
\hline \multicolumn{6}{|c|}{ Log likelihood-208,89892 } \\
\hline LR chi2 (1) & 8,00 & & & & \\
\hline Prob $>$ chi 2 & 0,0047 & & & & \\
\hline Pseudo $\mathrm{R}^{2}$ & 0,0188 & & & & \\
\hline Área Embaixo ROC & 0,5818 & & & & \\
\hline \multicolumn{6}{|c|}{ * Significante pelo menos a $10 \%$} \\
\hline \multicolumn{6}{|c|}{$* *$ Significante pelo menos a $5 \%$} \\
\hline$* * *$ Significante pelc & os a $1 \%$ & & & & \\
\hline
\end{tabular}

Calculando a Odds Ratio para a variável que diz respeito se o indivíduo trabalha ou estagia, tem-se que:

$e^{-0,6626478}=0,5154846$

Por ele, verifica-se que um aluno que estagia ou trabalha possuí uma chance 48,45\% menor de utilizar a heurística da representatividade, quando comparado ao aluno que não trabalha nem estagia, ceteris paribus e na presença das demais variáveis. Isso leva a conclusão de que a experiência profissional pode produzir resultados diversos nesse cenário.

\subsubsection{Questão 8 - Estudantes da Faculdade de Economia, Administração e Contabilidade da Universidade de São Paulo}

A hipótese 10 dessa tese foi testada através da questão 8. Seu objetivo era verificar se os respondentes não conseguiam enxergar o efeito de regressão à média de uma dada variável aleatória.

Conforme discorrido no capítulo de procedimentos metodológicos adotados, tal questão apresentava uma compilação dos resultados de uma empresa nos últimos 10 exercícios. $\mathrm{O}$ menor resultado de exercício era referente ao período mais recente. Contudo, o mesmo flutuava em torno de uma média maior do que o mínimo da série. Assim sendo, se o indivíduo visse o efeito de regressão à média, ele tenderia comprar a ação dessa empresa, pois ele julgaria que a mesma cresceria. 
Dos 369 respondentes, 192 (52,03\%) indivíduos não comprariam a ação dessa empresa. Isto relata a presença de indícios de que a maioria não conseguiu ver o efeito de regressão à média comentado a priori.

Entretanto, ao se aplicar o teste de hipóteses apropriado para $\mathrm{p}_{0}=0,5$ e $\mathrm{p}_{0}=0,75$, não se pode rejeitar as hipóteses nulas acima delineadas. Para as hipóteses alternativas $\mathrm{p}_{0}>0,5$ e $\mathrm{p}_{0}>0,75$, os p-values de ambos os testes foram de 0,2174 e 1,000 respectivamente. Logo, considerando um nível de significância de 5\%, não há indícios de que a maioria dos alunos da FEA/USP não consigam enxergar o efeito de regressão à média, pois em termos populacionais, não se pode refutar que a verdadeira proporção seja igual a $50 \%$.

Ainda assim, uma regressão logística foi feita para explicar se existe alguma característica social e acadêmica que poderia explicar o fato de $52,03 \%$ dos respondentes terem dito que não comprariam a ação.

Assim, o seguinte conjunto de variáveis explicativas foi utilizado: 


\begin{tabular}{|c|c|c|}
\hline $\begin{array}{c}\text { Conjunto de Variáveis Explicativas - Regressão } \\
\text { Logística - Hip. } 10 \text { (regressão à média)- } \\
\text { FEA/USP }\end{array}$ & Categorias da Variável ou Escala de Medida & Categoria de Referência \\
\hline Gênero & Feminino ou Masculino & Feminino \\
\hline Estado Civil & $\begin{array}{l}\text { Solteiro(a), Casado(a), Divorciado(a) ou } \\
\text { Viúvo(a) }\end{array}$ & Casado \\
\hline Idade & Dado em anos & \\
\hline \multicolumn{3}{|l|}{ Número de Filhos } \\
\hline Curso & $\begin{array}{l}\text { Ciências Contábeis, Ciências Econômicas, } \\
\text { Ciências Atuariais ou Outros }\end{array}$ & Outros \\
\hline Período do Curso & Diurno ou Noturno & Diurno \\
\hline Ano no Curso & Dado em anos & \\
\hline Trabalha ou Estagia & Sim ou Não & Não \\
\hline Há Quanto Tempo Trabalha & Dado em anos & \\
\hline Participou ou Participa de Iniciação Científica & Sim ou Não & Não \\
\hline Possui Outra Formação & Sim ou Não & Não \\
\hline Respondeu de acordo com a hipótese 1 & Sim ou Não & Não \\
\hline Respondeu de acordo com a hipótese 2 & Sim ou Não & Não \\
\hline Respondeu de acordo com a hipótese 3 & Sim ou Não & Não \\
\hline Respondeu de acordo com a hipótese 6 & Sim ou Não & Não \\
\hline Respondeu de acordo com a hipótese 7 & Sim ou Não & Não \\
\hline Respondeu de acordo com a hipótese 9 & Sim ou Não & Não \\
\hline
\end{tabular}

Quadro 12 - Conjunto de Variáveis Explicativas - Regressão Logística - Hip. 10 (regressão à média) - FEA/USP

O resultado do modelo é tal que:

Tabela 13 - Resultado da Regressão Logística - Hip. 10 (regressão à média) - FEA/USP

\begin{tabular}{|l|c|c|c|c|c|}
\hline & $\begin{array}{c}\text { Coeficiente } \\
\text { estimado }\end{array}$ & Erro Padrão & $\mathrm{z}$ & P-value & $\begin{array}{c}\text { Intervalo de Confiança - } \\
95 \%\end{array}$ \\
\hline Hipótese 2-Sim** & 0,5392416 & 0,253355 & 2,13 & 0,033 & {$[0,0426748 ; 1,035808]$} \\
\hline Constante & $-0,0953102$ & 0,1261312 & $-0,76$ & 0,450 & {$[-0,3425229 ; 0,1519025]$} \\
\hline Log likelihood-232,59954 & & & \\
LR chi2 (1) & & & \\
Prob> chi2 & 4,61 & & \\
Pseudo R ${ }^{2}$ & 0,0318 & & \\
Área Embaixo ROC & 0,0098 & & \\
* Significante pelo menos a 10\% & & \\
** Significante pelo menos a 5\% & & \\
*** Significante pelo menos a 1\%
\end{tabular}

Por ele, vê-se que os alunos que sofreram o efeito reflexão, isto é, arriscaram na perda, foram os que não viram o efeito de regressão à média. De fato, em modelo logístico anteriormente apresentado, quando a variável dependente era quem sofria o efeito reflexão, os alunos que 
não tinham visto o efeito de regressão à média já tinha se mostrado estatisticamente significativo.

Esse fato possui uma implicação interessante para os alunos que sofreram tanto o efeito reflexão e a não visão do efeito de regressão à média. Eles normalmente não são agressivos em sua postura de investimentos, dado que o fato de a série de resultados estar no seu ponto mínimo já foi o suficiente para que eles não comprassem a ação da empresa. Contudo, quando diante de uma perda, eles passam a ser extremamente agressivos. Essa visão colabora com a Prospect Theory de Kahneman e Tversky.

Finalmente, calculando-se a Odds Ratio dessa variável, tem-se que:

$e^{0,5392416}=1,714706$

A mesma revela que um aluno que sofreu o efeito reflexão possui uma chance $71,47 \%$ maior de não enxergar o efeito de regressão à média quando comparado a um aluno que não sofreu o efeito reflexão. Vale a pena complementar que essa constatação é ceteris paribus e na presença das demais variáveis.

\subsection{Profissionais de uma Grande Instituição Financeira do Brasil}

A seguir, são levantados os resultados obtidos com os profissionais de uma grande instituição financeira do Brasil (IF). Posteriormente, é apresentada uma comparação entre o observado com os estudantes da FEA/USP e da instituição financeira.

\subsubsection{Perfil dos Respondentes - Estatísticas Descritivas}

Foram submetidos 120 questionários aos profissionais e analistas de uma grande instituição financeira do Brasil. 55 questionários foram preenchidos. Destes, 36 eram homens $(65,45 \%)$, o que denota que a maior parte dessa amostra era composta por pessoas do sexo masculino, o que pode sugerir que eles sejam menos conservadores (Dantas e Macedo, 2013).

Diferentemente do perfil dos estudantes, a maioria dos indivíduos disse ser casada, isto é, 37 $(67,27 \%)$ sujeitos eram casados, $14(25,45 \%)$ eram solteiros e $4(7,27 \%)$ eram divorciados. 
Novamente, se assume que pessoas casadas tendem a atuar mais preponderantemente como chefes de família, o que faz com que eles sejam menos propensos a tomarem riscos se comparados aos solteiros. Logo, é de se esperar que os profissionais dessa instituição financeira, no geral, sejam mais conservadores do que os estudantes da FEA/USP.

Colaborando com a afirmação acima, 32 (58,18\%) respondentes possuíam ao menos um filho, que corrobora com o perfil mais conservador ensejado acima. Discutindo sobre a distribuição do número de filhos propriamente dita, verificou-se que 23 (41,82\%) não possuíam nenhum filho, 18 (32,73\%) possuíam um único filho, 10 (18,18\%) tinham 2 fillhos e 4 (7,27\%) tinham mais de 3 filhos.

Abaixo, encontra-se um histograma da variável idade dos respondentes. É importante comentar que existiram 4missingvalues, isto é, 4 respondentes não informaram sua idade.

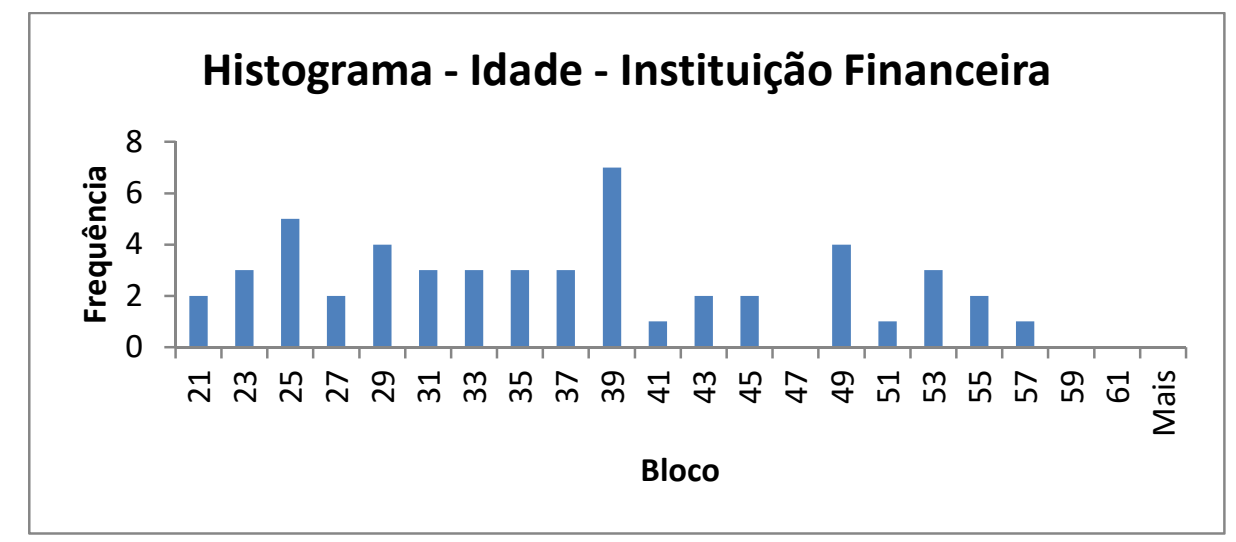

Figura 7 - Histograma de Idade (Profissionais da Instituição Financeira)

O histograma reflete que na amostra de profissionais, encontravam-se respondentes das mais variadas faixas etárias. De fato, essa distribuição apresentou baixa assimetria. O coeficiente de assimetria de Pearson foi de aproximadamente 0,30 . Foram observados os seguintes percentis: 
Tabela 14 - Percentis da Variável Idade para os analistas da Instituição Financeira

\begin{tabular}{|c|c|}
\hline Percentil & Idade \\
\hline $1 \%$ & 21 \\
\hline $5 \%$ & 21 \\
\hline $10 \%$ & 22 \\
\hline $25 \%$ & 22 \\
\hline $50 \%$ & 36 \\
\hline $75 \%$ & 44 \\
\hline $90 \%$ & 52 \\
\hline $95 \%$ & 54 \\
\hline $99 \%$ & 57 \\
\hline
\end{tabular}

A variável idade tinha um mínimo de 21 anos e um máximo de 57 anos. A tabela acima revela que até $25 \%$ da amostra era composta por profissionais em início de carreira (até 22 anos de idade). Por sua vez, outros 25\% tinham até 36 anos, ao passo que 75\% tinham até 44 anos. Como se vislumbra, essa análise está de acordo com a ideia de que a distribuição possui baixa assimetria, englobando profissionais das mais diferentes idades e cargos na hierarquia profissional.

Para fins elucidativos, os indivíduos apresentaram uma média de 36,37 anos, uma variância de 105,16 anos ao quadrado e um desvio-padrão de 10,25 anos. A pequena diferença entre a média e a mediana também está de acordo com a baixa assimetria observada.

Dos 55 respondentes, $35(63,64 \%)$ tinham formação em um curso de ciências sociais aplicadas, isto é, eram graduados em Administração de Empresas, Ciências Econômicas, Ciências Contábeis ou cursos correlatos, tais como Comércio Exterior, Marketing, etc. Por sua vez, 14 (25,45\%) possuíam formação em alguma Engenharia ou algum outro curso de Ciências Exatas, como Estatística, Ciências da Computação, etc. Finalmente, 6 (10,91\%) tinham formações diversas, como Jornalismo e Letras.

Logo, a maioria dos respondentes teve educação formal, mesmo que em nível mais introdutório, sobre os temas abordados no questionário. Não obstante, mesmo os que não tiveram, trabalham diariamente com os sistemas contábeis da empresa e tomam decisões de negócio envolvendo tais dados, o que requer algum tipo de expertise. Em conversas privadas, muitos alegaram terem feitos cursos Master in Business Administration (MBA), o que fortalece esse posicionamento. 
Vale a pena complementar que os profissionais que responderam esse questionário eram de áreas como Relacionamento com o Mercado. Não obstante, os que não eram e fazem uso de sistemas contábeis para tomadas de decisão de negócios internas (controladoria e estudos voltados à rentabilidade de clientes, etc).

Apesar de lidarem diariamente com esse tipo de informação, somente 27 (49,09\%) disseram já ter investido em renda variável para fins pessoais, ao passo que $47(85,45 \%)$ alegaram já terem investido em renda fixa. Esse resultado não surpreende, dado que a cultura brasileira de investimento não é muito forte em renda variável, sendo provavelmente ainda menor se a amostra fosse aleatória. Esse número já foi alto em virtude de serem profissionais de uma grande instituição financeira brasileira.

O que realmente surpreende é que dos 27 que já investiram em renda variável, somente 9 $(33,33 \%)$ alegaram que usam os relatórios financeiros e contábeis divulgados pelas empresas para embasar seu processo de decisão. Isso pode sinalizar que a informação contábil não é vista como relevante para esses indivíduos (a nível pessoal), mesmo que eles trabalhem diariamente com a mesma (alguns considerando sistemas contábeis internos).

\subsubsection{Questão 1 - Profissionais de uma Grande Instituição Financeira Brasileira}

De modo análogo aos procedimentos estatísticos aplicados com a amostra de alunos da FEA/USP, todos estes também foram feitos com a amostra dos analistas de uma das principais instituições financeiras do Brasil.

Assim sendo, conforme já discorrido, a hipótese 1 estava associada ao efeito certeza. Em termos de estatísticas descritivas, de um total de 55 sujeitos, 27 (49,09\%) responderam que já recomendariam a venda da referida ação. Tal como no universo de estudantes, isso já se configura como um forte indício de que a hipótese 1 dessa tese também é rejeitada para o universo de profissionais dessa instituição financeira.

Desse modo, com o teste de hipóteses apropriado para $\mathrm{p}_{0}=0,5$, verificou-se se a proporção de indivíduos que assinalaram de acordo com a hipótese 1 era estatisticamente igual a 50\%. Para a hipótese alternativa $p_{0}>0,5$, foi obtido um $p$-value de 0,5536 . De modo estritamente 
análogo, para uma hipótese nula de $\mathrm{p}_{0}=0,75$ e uma alternativa de $\mathrm{p}_{0}>0,75$, foi encontrado um $p$-value de 1,000 .

Logo, os dados não corroboram com a hipótese de que a maioria dos analistas da IF sofram do efeito certeza.

Ainda assim, uma regressão logística foi feita para identificar o que levou 49,09\% da amostra a sofrer esse efeito. Abaixo, encontra-se o vetor de variáveis explicativas utilizado para essa regressão:

\begin{tabular}{|l|l|l|}
\hline \multicolumn{1}{|c|}{$\begin{array}{c}\text { Conjunto de Variáveis Explicativas - Regressão } \\
\text { Logística - Hip. 1 (efeito certeza)- IF }\end{array}$} & Categorias da Variável ou Escala de Medida & Categoria de Referência \\
\hline Gênero & Feminino ou Masculino & Feminino \\
\hline Estado Civil & $\begin{array}{l}\text { Solteiro(a), Casado(a), Divorciado(a) ou } \\
\text { Viúvo(a) }\end{array}$ & Casado \\
\hline Idade & Dado em anos & \\
\hline Número de Filhos & & \\
\hline Categoria do curso em que se formou & $\begin{array}{l}\text { Ciências Aplicadas, } \\
\text { Engenharia/Computação, Outros }\end{array}$ & Ciências Sociais Aplicadas \\
\hline Se já investiu em Renda Variável & Sim ou Não & Não \\
\hline Se já investiu em Renda Fixa & Sim ou Não & Não \\
\hline $\begin{array}{l}\text { Se usa as Informações Contábeis na Tomada de } \\
\text { Decisão }\end{array}$ & Sim ou Não & Não \\
\hline Respondeu de acordo com a hipótese 2 & Sim ou Não & Não \\
\hline Respondeu de acordo com a hipótese 3 & Sim ou Não & Não \\
\hline Respondeu de acordo com a hipótese 6 & Sim ou Não & Não \\
\hline Respondeu de acordo com a hipótese 7 & Sim ou Não & Não \\
\hline Respondeu de acordo com a hipótese 9 & Sim ou Não & Não \\
\hline Respondeu de acordo com a hipótese 10 & Sim ou Não & Não \\
\hline
\end{tabular}

Quadro 13 - Conjunto de Variáveis Explicativas - Regressão Logística - Hip. 1 (efeito certeza) Instituição Financeira

Com isso, foi obtido o seguinte modelo: 
Tabela 15 - Resultado da Regressão Logística - Hip. 1 (efeito certeza) - Instituição Financeira

\begin{tabular}{|c|c|c|c|c|c|}
\hline & $\begin{array}{l}\text { Coeficiente } \\
\text { estimado }\end{array}$ & Erro Padrão & $\mathrm{Z}$ & $P$-value & $\begin{array}{c}\text { Intervalo de Confiança - } \\
95 \%\end{array}$ \\
\hline Constante & 0 & 0,3429972 & 0,00 & 1,000 & {$[-0,6722621 ; 0,6722621]$} \\
\hline \multicolumn{6}{|c|}{ Log likelihood-101,9915 } \\
\hline LR chi2 $(0)$ & 8,65 & & & & \\
\hline Prob $>$ chi 2 & 0,0132 & & & & \\
\hline Pseudo $\mathrm{R}^{2}$ & 0,0407 & & & & \\
\hline Área Embaixo ROC & 0,6281 & & & & \\
\hline \multicolumn{6}{|c|}{ * Significante pelo menos a $10 \%$} \\
\hline \multicolumn{6}{|c|}{ ** Significante pelo menos a $5 \%$} \\
\hline$* * *$ Significante pel & a $1 \%$ & & & & \\
\hline
\end{tabular}

Tal como se verifica, nenhuma das variáveis explicativas foi capaz de explicar o que levou esses $49,09 \%$ a optarem pela recomendação imediata da venda da ação agora.

Já no tocante a como os profissionais da IF se comportam quando confrontados diante de uma perda certa, $36(65,45 \%)$ da amostra se mostrou disposta a arriscar, recomendando a venda da ação somente no final do ano. Esse resultado preliminar, por si só, já se configura como uma indicação de que a hipótese 2 dessa tese, diferentemente do observado pelos alunos da FEA/USP, não pode ser refutada para o universo dos analistas dessa IF.

De fato, ao se fazer o teste de hipóteses apropriado para $\mathrm{p}_{0}=0,5$ e $\mathrm{p}_{0}=0,75$, obteve-se os $p$ values de 0,0109 e 0,9490 contra as hipóteses alternativas $\mathrm{p}_{0}>0,5$ e $\mathrm{p}_{0}>0,75$, respectivamente. Considerando uma probabilidade de erro do tipo I de 5\%, pode-se afirmar de que a proporção da população de analistas dessa IF que estariam propensos a arriscar em uma situação de perda certa é superior a $50 \%$, mas inferior a $75 \%$. Desse modo, não se pode refutar a hipótese 2 dessa tese para os profissionais dessa IF.

Considerando procedimentos metodológicos já empregados nessa tese, também foi feita uma regressão logística para levantar variáveis que poderiam explicar esse procedimento. $\mathrm{O}$ conjunto de variáveis explicativas se encontra discriminado abaixo: 


\begin{tabular}{|l|l|l|}
\hline $\begin{array}{c}\text { Conjunto de Variáveis Explicativas - Regressão } \\
\text { Logística - Hip. 2 (efeito reflexão)- IF }\end{array}$ & Categorias da Variável ou Escala de Medida & Categoria de Referência \\
\hline Gênero & Feminino ou Masculino & Feminino \\
\hline Estado Civil & $\begin{array}{l}\text { Solteiro(a), Casado(a), Divorciado(a) ou } \\
\text { Viúvo(a) }\end{array}$ & Casado \\
\hline Idade & Dado em anos & \\
\hline Número de Filhos & & \\
\hline Categoria do curso em que se formou & $\begin{array}{l}\text { Ciências Aplicadas, } \\
\text { Engenharia/Computação, Outros }\end{array}$ & Ciências Sociais Aplicadas \\
\hline Se já investiu em Renda Variável & Sim ou Não & Não \\
\hline Se já investiu em Renda Fixa & Sim ou Não & Não \\
\hline $\begin{array}{l}\text { Se usa as Informações Contábeis na Tomada de } \\
\text { Decisão }\end{array}$ & Sim ou Não & Não \\
\hline Respondeu de acordo com a hipótese 1 & Sim ou Não & Não \\
\hline Respondeu de acordo com a hipótese 3 & Sim ou Não & Não \\
\hline Respondeu de acordo com a hipótese 6 & Sim ou Não & Não \\
\hline Respondeu de acordo com a hipótese 7 & Sim ou Não & Não \\
\hline Respondeu de acordo com a hipótese 9 & Sim ou Não & Não \\
\hline Respondeu de acordo com a hipótese 10 & Sim ou Não & Não \\
\hline
\end{tabular}

Quadro 14 - Conjunto de Variáveis Explicativas - Regressão Logística - Hip. 2 (efeito reflexão) Instituição Financeira

O seguinte modelo foi encontrado:

Tabela 16 - Resultado da Regressão Logística - Hip. 2 (efeito reflexão) - Instituição Financeira

\begin{tabular}{|l|c|c|c|c|c|}
\hline & $\begin{array}{c}\text { Coeficiente } \\
\text { estimado }\end{array}$ & Erro Padrão & $\mathrm{z}$ & P-value & $\begin{array}{c}\text { Intervalo de Confiança - } \\
95 \%\end{array}$ \\
\hline Solteiro** & 2,181957 & 1,090433 & 2,00 & 0,045 & {$[0,0447475 ; 4,319166]$} \\
\hline Constante & 0,3829923 & 0,3348451 & 1,14 & 0,253 & {$[-0,273292 ; 1,039277]$} \\
\hline Log likelihood-28,582737 & & & \\
LR chi2 (1) & & & \\
Prob> chi2 & 6,28 & & \\
Pseudo R ${ }^{2}$ & 0,0122 & & \\
Área Embaixo ROC & 0,0990 & & \\
* Significante pelo menos a 10\% & & & \\
** Significante pelo menos a 5\% & & \\
*** Significante pelo menos a 1\%
\end{tabular}

Como se verifica, o fato do indivíduo ser solteiro foi estatisticamente significativo considerando um nível de significância de 5\%.

Calculando a Odds Ratio para a variável em questão, tem-se que: 
Isto implica em dizer que, ceteris paribus, e na presença das demais variáveis, um indivíduo solteiro tem $786,36 \%$ mais chance de arriscar diante de uma perda certa, quando comparado a um indivíduo casado. Esse achado não contradiz empiricamente o fato de que indivíduos solteiros são mais propensos a tomarem o risco.

Finalmente, a hipótese 3 dizia respeito ao efeito isolamento, isto é, se cada par de decisão era tomado individualmente ou se o respondente considerava o fato explicitamente discriminado de que se tratava de um par de decisões relacionado.

Dos 55 analistas da IF, $45(81,82 \%)$ não responderam de acordo com o cenário que trazia maior esperança matemática, o que fortalece a hipótese 3, isto é, a maioria dos indivíduos não consideram o par de decisões conjuntamente.

Os testes de hipóteses para $\mathrm{p}_{0}=0,5$ e $\mathrm{p}_{0}=0,75$ apresentaram $p$-values de 0,0000 e 0,1215 , respectivamente. Isso implica em dizer que para um nível de significância de 5\%, pode-se dizer que a proporção de todos os analistas da IF que não escolheriam a combinação ótima é superior a $50 \%$, mas inferior a $75 \%$.

Logo, o efeito isolamento foi observado tanto no universo de estudantes da FEA/USP quanto no de profissionais da IF, garantindo-lhe um caráter mais holístico.

Com vistas a estimar quais variáveis poderiam explicar o porquê da maioria dos analistas sofrerem o efeito isolamento, uma nova regressão logística foi feita. Vale a pena ressaltar que levando em consideração que a hipótese 3 (efeito isolamento) é função das hipóteses 1 (efeito certeza) e 2 (efeito reflexão), isto implica em dizer que a variável dependente do modelo não pode incluir as outras duas como explicativas. Assim sendo, tem-se o seguinte conjunto de variáveis explicativas: 


\begin{tabular}{|l|l|l|}
\hline $\begin{array}{c}\text { Conjunto de Variáveis Explicativas - Regressão } \\
\text { Logística - Hip. 3 (efeito isolamento)- IF }\end{array}$ & Categorias da Variável ou Escala de Medida & Categoria de Referência \\
\hline Gênero & Feminino ou Masculino & Feminino \\
\hline Estado Civil & $\begin{array}{l}\text { Solteiro(a), Casado(a), Divorciado(a) ou } \\
\text { Viúvo(a) }\end{array}$ & Casado \\
\hline Idade & Dado em anos & \\
\hline Número de Filhos & & Aplicadas, \\
\hline Categoria do curso em que se formou & $\begin{array}{l}\text { Ciências Sociais Sociais Aplicadas } \\
\text { Engenharia/Computação, Outros }\end{array}$ & \\
\hline Se já investiu em Renda Variável & Sim ou Não & Não \\
\hline Se já investiu em Renda Fixa & Sim ou Não & Não \\
\hline $\begin{array}{l}\text { Se usa as Informações Contábeis na Tomada de } \\
\text { Decisão }\end{array}$ & Sim ou Não & Não \\
\hline Respondeu de acordo com a hipótese 6 & Sim ou Não & Não \\
\hline Respondeu de acordo com a hipótese 7 & Sim ou Não & Não \\
\hline Respondeu de acordo com a hipótese 9 & Sim ou Não & Não \\
\hline Respondeu de acordo com a hipótese 10 & Sim ou Não & Não \\
\hline
\end{tabular}

Quadro 15 - Conjunto de Variáveis Explicativas - Regressão Logística - Hip. 3 (efeito isolamento) - Instituição Financeira

O seguinte modelo foi obtido:

Tabela 17 - Resultado da Regressão Logística - Hip. 3 (efeito isolamento) - Instituição Financeira

\begin{tabular}{|c|c|c|c|c|c|}
\hline & $\begin{array}{c}\text { Coeficiente } \\
\text { estimado }\end{array}$ & Erro Padrão & $\mathrm{z}$ & $P$-value & $\begin{array}{c}\text { Intervalo de Confiança - } \\
95 \%\end{array}$ \\
\hline Divorciado** & $-2,80336$ & 1,237054 & $-2,27$ & 0,023 & {$[-5,227942 ;-0,3787788]$} \\
\hline Constante*** & 1,704748 & 0,4438127 & 3,84 & 0,000 & {$[0,8348912 ; 2,574605]$} \\
\hline \multicolumn{6}{|c|}{ Log likelihood-18,992938 } \\
\hline LR chi2 (1) & 6,13 & & & & \\
\hline Prob $>$ chi 2 & 0,0133 & & & & \\
\hline Pseudo $\mathrm{R}^{2}$ & 0,1390 & & & & \\
\hline Área Embaixo ROC & 0,6520 & & & & \\
\hline \multicolumn{6}{|c|}{ * Significante pelo menos a $10 \%$} \\
\hline \multicolumn{6}{|c|}{ ** Significante pelo menos a $5 \%$} \\
\hline \multicolumn{6}{|c|}{$* * *$ Significante pelo menos a $1 \%$} \\
\hline
\end{tabular}

Como se observa, o fato do analista ser divorciado foi estatisticamente significativo (a 95\% de confiança) em explicar o porquê da maioria desses profissionais terem incorrido no efeito isolamento. Calculando a Odds Ratio para essa variável:

$e^{-2,80336}=0,0606061$ 
Logo, na presença das demais variáveis e ceteris paribus, um analista que é divorciado tem uma chance $93,94 \%$ menor de incorrer ao efeito isolamento se comparado a um sujeito casado. Não há literatura que explique esse fenômeno observado.

\subsubsection{Questão 2 - Profissionais de uma Grande Instituição Financeira Brasileira}

Tal como discorrido anteriormente, a questão 2tinha como objetivo verificar se a heurística da ancoragem influenciava a decisão dos respondentes (hipótese 4). Logo, existiam duas versões de uma mesma questão, sendo uma ancorada na perda e outra na não perda.

De um total de 55 respondentes, 28 responderam a versão ancorada na perda, ao passo em que 27 responderam a outra versão. Na versão ancorada na perda, 21 (75,00\%) recomendaram a compra da ação, ao passo em que na segunda versão, 18 (66,67\%) também recomendaram a compra da ação.

Tal como na análise dos resultados da hipótese 2 para os estudantes, os achados novamente podem ser vistos como conflitantes, na medida em que levantam a ideia de que a proporção de indivíduos que recomendam a compra da ação em uma situação ancorada na perda é maior do que na não perda.

Contudo, a aplicação do teste de hipóteses que busca verificar se existe diferença nas proporções observadas entre as versões, também revela, que a um nível de significância de $5 \%$, não existem indícios de que haja diferença entre uma abstrata população de profissionais que responderia a versão ancorada na perda e outra ancorada na não perda. Novamente, assumindo que a hipótese nula do teste seja de que a diferença é igual a 0 , para a hipótese alternativa de que a diferença é diferente de 0 , foi obtido um p-value de 0,4963.

Logo, a hipótese 4 da tese foi refutada tanto para o universo de estudantes da FEA/USP quanto para os analistas da IF, o que pode fortalecer a ideia de que a essência econômica prevaleça sobre a forma.

Ainda assim, uma regressão logística foi feita com vistas a estimar quais variáveis poderiam explicar efetivamente a recomendação da ação. Desse modo, o conjunto de variáveis explicativas do modelo foi: 


\begin{tabular}{|l|l|l|}
\hline $\begin{array}{c}\text { Conjunto de Variáveis Explicativas - Regressão } \\
\text { Logística - Hip. 4 (efeito ancoragem)- IF }\end{array}$ & Categorias da Variável ou Escala de Medida & Categoria de Referência \\
\hline Gênero & Feminino ou Masculino & Feminino \\
\hline Estado Civil & $\begin{array}{l}\text { Solteiro(a), Casado(a), Divorciado(a) ou } \\
\text { Viúvo(a) }\end{array}$ & Casado \\
\hline Idade & Dado em anos & \\
\hline Número de Filhos & & Aplicadas, \\
\hline Categoria do curso em que se formou & $\begin{array}{l}\text { Ciências } \\
\text { Engenharia/Computação, Outros Sociais Aplicadas }\end{array}$ \\
\hline Se já investiu em Renda Variável & Sim ou Não & Não \\
\hline Se já investiu em Renda Fixa & Sim ou Não & Não \\
\hline $\begin{array}{l}\text { Se usa as Informações Contábeis na Tomada de } \\
\text { Decisão }\end{array}$ & Sim ou Não & Não \\
\hline Versão da Questão 2 & Ancorada na Perda ou na Não Perda & Perda \\
\hline Respondeu de acordo com a hipótese 1 & Sim ou Não & Não \\
\hline Respondeu de acordo com a hipótese 2 & Sim ou Não & Não \\
\hline Respondeu de acordo com a hipótese 3 & Sim ou Não & Não \\
\hline Respondeu de acordo com a hipótese 6 & Sim ou Não & Não \\
\hline Respondeu de acordo com a hipótese 7 & Sim ou Não & Não \\
\hline Respondeu de acordo com a hipótese 9 & Sim ou Não & Não \\
\hline Respondeu de acordo com a hipótese 10 & Sim ou Não & Não \\
\hline
\end{tabular}

Quadro 16 - Conjunto de Variáveis Explicativas - Regressão Logística - Hip. 4 (efeito ancoragem) - Instituição Financeira

Foi obtido o seguinte modelo:

Tabela 18 - Resultado da Regressão Logística - Hip. 4 (efeito ancoragem) - Instituição Financeira

\begin{tabular}{|c|c|c|c|c|c|}
\hline & Coeficiente estimado & Erro Padrão & $\mathrm{z}$ & $P$-value & $\begin{array}{c}\text { Intervalo de Confiança - } \\
95 \%\end{array}$ \\
\hline $\begin{array}{l}\text { Cursos de } \\
\text { Engenharia ou } \\
\text { Computação** }\end{array}$ & 2,704256 & 1,14109 & 2,37 & 0,018 & {$[0,4677602 ; 4,940752]$} \\
\hline Solteiro** & 2,586699 & 1,146886 & 2,26 & 0,024 & {$[0,3388431 ; 4,834554]$} \\
\hline Constante & $-0,4887985$ & 0,4488289 & $-1,09$ & 0,276 & {$[-1,368487 ; 0,39089]$} \\
\hline \multicolumn{6}{|c|}{ Log likelihood-20,362099 } \\
\hline \multicolumn{6}{|l|}{ LR chi2 (2)14,02 } \\
\hline Prob $>$ chi 2 & 0,0009 & & & & \\
\hline Pseudo $\mathrm{R}^{2}$ & 0,2561 & & & & \\
\hline Área Embaixo ROC & 0,7914 & & & & \\
\hline \multicolumn{6}{|c|}{ * Significante pelo menos a $10 \%$} \\
\hline \multicolumn{6}{|c|}{$* *$ Significante pelo menos a $5 \%$} \\
\hline$* * *$ Significante pelo & nos a $1 \%$ & & & & \\
\hline
\end{tabular}

Como já era de esperar, a versão da questão 2 não foi uma variável estatisticamente significativa considerando um erro do tipo I de 5\%. Entretanto, o fato do profissional ter feito um curso voltado às engenharias ou ciências da computação, além do estado civil ser solteiro 
se mostraram explicativas. Não obstante, esse é um dos melhores modelos na capacidade de discriminar o evento do não evento dessa tese, tendo em vista que a área embaixo da curva ROC foi de 0,7914 .

Calculando as Odds Ratio para as variáveis em questão, temos:

$$
\begin{aligned}
& e^{2,704256}=14,94319 \\
& e^{2,586699}=13,28584
\end{aligned}
$$

Logo, um profissional da instituição financeira que tenha feito algum curso de engenharia ou ciências da computação possui uma chance 1394,32\% maior de recomendar a compra da referida ação quando comparado a um analista formado em ciências sociais aplicadas, ao passo em que um solteiro possui uma chance $1228,58 \%$ maior quando comparado a um casado.

É importante mencionar que todas essas análises são ceteris paribus e na presença das demais variáveis.

Apesar da hipótese 4 ter sido refutada, esta regressão revela que solteiros podem ter maior propensão a investir no mercado de renda variável quando comparados à casados, o que não é uma surpresa, tendo em vista que eles tendem a ser mais agressivos que os últimos.

A observação empírica que merece menção é que no universo de analistas dessa IF, a formação em cursos de engenharia ou ciências da computação dão um caráter mais agressivo ao analista, quando comparado a um outro profissional formado em ciências sociais aplicadas.

\subsubsection{Questão 3 - Profissionais de uma Grande Instituição Financeira Brasileira}

A questão 3 (englobava a hipótese 5) dessa tese, de modo análogo às questões 2 e 6, também objetivava averiguar se o efeito de formulação também influenciava o processo decisório em um ambiente que usa informações contábeis. 
Tal como já explanado anteriormente, a questão possuía duas versões, sendo que uma apresentava o valor de um hipotético empréstimo apresentado em termos brutos, ao passo que na segunda, o mesmo era demonstrado na forma de alavancagem do patrimônio líquido.

Dentre os 28 profissionais que responderam a versão com o valor do empréstimo apresentado em termos brutos, $12(42,86 \%)$ aprovariam o empréstimo, mesmo em uma situação em que a empresa apresenta baixa liquidez corrente. Por sua vez, na segunda versão (em termos de alavancagem do patrimônio líquido), dos 27 analistas, 11 (40,74\%) também aprovariam o empréstimo.

A baixa diferença das proporções levantadas sugerem que a hipótese 5 também deve ser refutada para o universo de analistas da IF, assim como no caso dos alunos da FEA/USP. De fato, a aplicação do teste de hipóteses de diferença de proporções, revela que a um nível de significância de 5\%, não existem indícios de que haja diferenças entre uma abstrata população de analistas da IF que responderia a versão formulada em termos de valores brutos e uma em termos de alavancagem do patrimônio líquido. Assumindo que a hipótese nula do teste seja de que a diferença é igual a 0 , para a hipótese alternativa de que a diferença é diferente de 0 , obteve-se um p-value de 0,8736 , confirmando a intuição acima mencionada.

Novamente, é um indício que fortalece a ideia de que a essência sobre a forma persiste dentre o universo de analistas. Complementarmente a análise feita acima, uma regressão logística foi feita com vistas a levantar quais variáveis podem explicar ainda a aprovação de um empréstimo, mesmo em um cenário onde a empresa aparenta ter problemas de liquidez. Foi adotado o seguinte conjunto de variáveis explicativas: 


\begin{tabular}{|l|l|l|}
\hline $\begin{array}{c}\text { Conjunto de Variáveis Explicativas - Regressão } \\
\text { Logística (números brutos x números relativos) - } \\
\text { Hip. 5- IF }\end{array}$ & Categorias da Variável ou Escala de Medida & Categoria de Referência \\
\hline Gênero & Feminino ou Masculino & \\
\hline Estado Civil & $\begin{array}{l}\text { Solteiro(a), Casado(a), Divorciado(a) ou } \\
\text { Viúvo(a) }\end{array}$ & Casado \\
\hline Idade & Dado em anos & \\
\hline Número de Filhos & & \\
\hline Categoria do curso em que se formou & Ciências Aplicadas, & Ciências Sociais Aplicadas \\
\hline Se já investiu em Renda Variável & Engenharia/Computação, Outros & \\
\hline Se já investiu em Renda Fixa & Sim ou Não & Não \\
\hline $\begin{array}{l}\text { Se usa as Informações Contábeis na Tomada de } \\
\text { Decisão }\end{array}$ & Sim ou Não & Nim ou Não \\
\hline Versão da Questão 3 & Ancorada em Números Brutos ou em & Ancorada em Números Brutos \\
\hline Respondeu de acordo com a hipótese 1 & Números Relativos & \\
\hline Respondeu de acordo com a hipótese 2 & Sim ou Não & Não \\
\hline Respondeu de acordo com a hipótese 3 & Sim ou Não & Não \\
\hline Respondeu de acordo com a hipótese 6 & Sim ou Não & Não \\
\hline Respondeu de acordo com a hipótese 7 & Sim ou Não & Não \\
\hline Respondeu de acordo com a hipótese 9 & Sim ou Não & Não \\
\hline Respondeu de acordo com a hipótese 10 & Sim ou Não \\
\hline
\end{tabular}

Quadro 17 - Conjunto de Variáveis Explicativas - Regressão Logística - Hip. 5 (números brutos $\mathrm{x}$ números relativos) - Instituição Financeira

Assim sendo, obteve-se o seguinte modelo:

Tabela 19 - Resultado da Regressão Logística - Hip. 5 (números brutos x números relativos) - Instituição Financeira

\begin{tabular}{|c|c|c|c|c|c|}
\hline & $\begin{array}{l}\text { Coeficiente } \\
\text { estimado }\end{array}$ & Erro Padrão & $\mathrm{z}$ & $P$-value & $\begin{array}{c}\text { Intervalo de Confiança - } \\
95 \%\end{array}$ \\
\hline Constante & $-0,1967103$ & 0,2814117 & $-0,70$ & 0,485 & {$[-0,7482671 ; 0,3548465]$} \\
\hline \multicolumn{6}{|c|}{ Log likelihood-35,105014 } \\
\hline LR chi2 (0) & 0,00 & & & & \\
\hline \multicolumn{6}{|l|}{ Prob $>$ chi 2} \\
\hline Pseudo $\mathrm{R}^{2}$ & 0,0000 & & & & \\
\hline Área Embaixo ROC & 0,50 & & & & \\
\hline \multicolumn{6}{|c|}{ * Significante pelo menos a $10 \%$} \\
\hline \multicolumn{6}{|c|}{ ** Significante pelo menos a $5 \%$} \\
\hline$* * *$ Significante pelc & os a $1 \%$ & & & & \\
\hline
\end{tabular}

Como se verifica, nenhuma das variáveis do modelo foi capaz de explicar o que levou a aproximadamente metade da amostra de profissionais a aprovar o empréstimo.

\subsubsection{Questão 4 - Profissionais de uma Grande Instituição Financeira Brasileira}


A questão 4 trazia embutida nela a hipótese 6 dessa tese. A mesma buscava verificar se os respondentes sofriam os efeitos da correlação ilusória ou se tinham problemas em identificar o sentido estatístico por detrás da correlação.

Assim sendo, do total da amostra de analistas da IF, $33(60,0 \%)$ recomendaram a compra de uma ação de uma empresa do mesmo grupo (coligada ou controlada) como forma de garantir o lucro do próximo período, o que sugere que há indícios de que a maioria dos profissionais dessa IF também sofram os efeitos da correlação ilusória, de modo similar ao visto com os alunos da FEA/USP.

Os testes de hipóteses de proporção para $\mathrm{p}_{0}=0,5$ e $\mathrm{p}_{0}=0,75$ corroboram com essa intuição observada nessa estatística descritiva. Para as hipóteses alternativas $\mathrm{p}_{0}>0,5$ e $\mathrm{p}_{0}>0,75$, os $p$ values de ambos os testes foram de 0,0690 e 0,9940 respectivamente. Logo, adotando uma postura menos conservadora, isto é, considerando um nível de significância de $10 \%$ e não de $5 \%$, pode-se dizer que a verdadeira proporção de profissionais dessa IF que possuem problemas em identificar o sentido estatístico por detrás da correlação é superior a $50 \%$, mas inferior a $75 \%$.

De modo equivalente, uma regressão logística foi feita para identificar o que levou a $60 \%$ da amostra de analistas da IF a se comportarem como o propugnado pela hipótese 6. Assim sendo, foi adotado o seguinte conjunto de variáveis explicativas: 


\begin{tabular}{|l|l|l|}
\hline $\begin{array}{c}\text { Conjunto de Variáveis Explicativas - Regressão } \\
\text { Logística - Hip. 6 (correlação ilusória)- IF }\end{array}$ & Categorias da Variável ou Escala de Medida & Categoria de Referência \\
\hline Gênero & Feminino ou Masculino & Feminino \\
\hline Estado Civil & $\begin{array}{l}\text { Solteiro(a), Casado(a), Divorciado(a) ou } \\
\text { Viúvo(a) }\end{array}$ & Casado \\
\hline Idade & Dado em anos & \\
\hline Número de Filhos & & \\
\hline Categoria do curso em que se formou & $\begin{array}{l}\text { Ciências Aplicadas, } \\
\text { Engenharia/Computação, Outros }\end{array}$ & Ciências Sociais Aplicadas \\
\hline Se já investiu em Renda Variável & Sim ou Não & Não \\
\hline Se já investiu em Renda Fixa & Sim ou Não & Não \\
\hline $\begin{array}{l}\text { Se usa as Informações Contábeis na Tomada de } \\
\text { Decisão }\end{array}$ & Sim ou Não & Não \\
\hline Respondeu de acordo com a hipótese 1 & Sim ou Não & Não \\
\hline Respondeu de acordo com a hipótese 2 & Sim ou Não & Não \\
\hline Respondeu de acordo com a hipótese 3 & Sim ou Não & Não \\
\hline Respondeu de acordo com a hipótese 7 & Sim ou Não & Não \\
\hline Respondeu de acordo com a hipótese 9 & Sim ou Não & Não \\
\hline Respondeu de acordo com a hipótese 10 & Sim ou Não & Não \\
\hline
\end{tabular}

Quadro 18 - Conjunto de Variáveis Explicativas - Regressão Logística - Hip. 6 (correlação ilusória) - Instituição Financeira

O seguinte modelo foi obtido:

Tabela 20 - Resultado da Regressão Logística - Hip. 6 (correlação ilusória) - Instituição Financeira

\begin{tabular}{|c|c|c|c|c|c|}
\hline & $\begin{array}{l}\text { Coeficiente } \\
\text { estimado }\end{array}$ & Erro Padrão & $\mathrm{z}$ & $P$-value & $\begin{array}{c}\text { Intervalo de Confiança- }- \\
95 \%\end{array}$ \\
\hline $\begin{array}{l}\text { Cursos de } \\
\text { Engenharia ou } \\
\text { Computação** }\end{array}$ & 2,569745 & 1,098199 & 2,34 & 0,019 & {$[0,4173153 ; 4,722175]$} \\
\hline Constante & $-0,1718503$ & 0,3393104 & $-0,51$ & 0,613 & {$[-0,8368865 ; 0,493186]$} \\
\hline \multicolumn{6}{|c|}{ Log likelihood-27,573454 } \\
\hline \multicolumn{6}{|l|}{ LR chi2 (1)8,96 } \\
\hline Prob $>$ chi2 & 0,0028 & & & & \\
\hline Pseudo $\mathrm{R}^{2}$ & 0,1398 & & & & \\
\hline Área Embaixo ROC & 0,6787 & & & & \\
\hline \multicolumn{6}{|c|}{ * Significante pelo menos a $10 \%$} \\
\hline \multicolumn{6}{|c|}{ ** Significante pelo menos a $5 \%$} \\
\hline *** Significante pelc & s $1 \%$ & & & & \\
\hline
\end{tabular}

Ter se graduado em um curso de engenharia ou ciências da computação se mostrou estatisticamente significativo (a um nível de confiança de 95\%) para explicar o porquê da maioria dos analistas terem sofrido o efeito de correlação ilusória.

Calculando a Odds Ratio da variável em questão: 
$e^{2,569745}=13,0625$

Isto implica em dizer que, ceteris paribus, e na presença das demais variáveis, um analista que é formado em cursos de engenharia ou ciências da computação tem uma chance 1206,25\% maior de incorrer no efeito de correlação ilusória se comparado a um profissional com formação em ciências sociais aplicadas.

Esse resultado pode ser interpretado sob dois vértices. Se for considerado que estes indivíduos não tiveram educação formal sobre processos de tomada de investimentos, ele realça a importância de um ensino formal sobre o tema, que aborda a teoria da diversificação.

Por sua vez, é de se esperar que um indivíduo formado em engenharia ou cursos da área de ciências da computação possua uma maior erudição em matemática e estatística. Nesse sentido, o fenômeno da correlação é estudado nesses cursos. Assim sendo, ele implica em dizer que mesmo se o indivíduo possua uma forte formação matemática, ele não está isento de sofrer o efeito da correlação ilusória.

\subsubsection{Questão 5 - Profissionais de uma Grande Instituição Financeira Brasileira}

Como já discorrido anteriormente, a questão 5 e sua respectiva hipótese 7 dessa tese tinha como objetivo investigar como à facilidade com que os indivíduos tinham de recuperar eventos pertencentes a uma determinada classe, ou seja, como a heurística da disponibilidade influenciava em um ambiente com informações contábeis.

Do total de 55 analistas da IF, 37 (67,27\%) não comprariam a ação de uma empresa que tinha passado recentemente por uma crise de corrupção, independentemente de a nota explicativa atentar que a empresa já tinha tomado boas práticas de governança.

Essa pequena estatística descritiva já se consubstancia como um indicativo de que a hipótese 7 dessa tese também não pode ser rejeitada no universo de analistas dessa IF. Logo, ao se aplicar o teste de hipóteses apropriado para $\mathrm{p}_{0}=0,5$ e $\mathrm{p}_{0}=0,75$, testou-se se a proporção de indivíduos que assinalaram de acordo com a hipótese 7 era estatisticamente igual a $50 \%$ e $75 \%$ respectivamente. Para as hipóteses alternativas $\mathrm{p}_{0}>0,5$ e $\mathrm{p}_{0}>0,75$, os $p$-values de ambos os testes foram de 0,0052 e 0,9072 respectivamente. Dessa maneira, a real proporção de 
analistas dessa IF que invocaria a heurística da disponibilidade é superior a 50\%, mas inferior a 75\%. Assim sendo, não há como refutar a hipótese 7 dessa tese, nem para os estudantes da FEA/USP (como visto anteriormente) e tampouco para os analistas dessa IF.

Tal como nos demais casos dessa tese, uma regressão logística foi feita. Foi adotado o seguinte conjunto de variáveis para explicar o fenômeno observado:

\begin{tabular}{|c|c|c|}
\hline $\begin{array}{c}\text { Conjunto de Variáveis Explicativas - Regressão } \\
\text { Logística - Hip. } 7 \text { (heurística da disponibilidade)- } \\
\text { IF }\end{array}$ & Categorias da Variável ou Escala de Medida & Categoria de Referência \\
\hline Gênero & Feminino ou Masculino & Feminino \\
\hline Estado Civil & $\begin{array}{l}\text { Solteiro(a), Casado(a), Divorciado(a) ou } \\
\text { Viúvo(a) }\end{array}$ & Casado \\
\hline Idade & Dado em anos & \\
\hline \multicolumn{3}{|l|}{ Número de Filhos } \\
\hline Categoria do curso em que se formou & $\begin{array}{lcl}\text { Ciências } & \text { Sociais } & \text { Aplicadas, } \\
\text { Engenharia/Computação, Outros } & \end{array}$ & Ciências Sociais Aplicadas \\
\hline Se já investiu em Renda Variável & Sim ou Não & Não \\
\hline Se já investiu em Renda Fixa & Sim ou Não & Não \\
\hline $\begin{array}{l}\text { Se usa as Informações Contábeis na Tomada de } \\
\text { Decisão }\end{array}$ & Sim ou Não & Não \\
\hline Respondeu de acordo com a hipótese 1 & Sim ou Não & Não \\
\hline Respondeu de acordo com a hipótese 2 & Sim ou Não & Não \\
\hline Respondeu de acordo com a hipótese 3 & Sim ou Não & Não \\
\hline Respondeu de acordo com a hipótese 6 & Sim ou Não & Não \\
\hline Respondeu de acordo com a hipótese 9 & Sim ou Não & Não \\
\hline Respondeu de acordo com a hipótese 10 & Sim ou Não & Não \\
\hline
\end{tabular}

Quadro 19 - Conjunto de Variáveis Explicativas - Regressão Logística - Hip. 7 (heurística da disponibilidade) - Instituição Financeira

O seguinte modelo foi obtido: 
Tabela 21 - Resultado da Regressão Logística - Hip. 7 (heurística da disponibilidade) - Instituição Financeira

\begin{tabular}{|c|c|c|c|c|c|}
\hline & Coeficiente estimado & Erro Padrão & $\mathrm{z}$ & $P$-value & $\begin{array}{c}\text { Intervalo de Confiança - } \\
95 \%\end{array}$ \\
\hline Idade $^{* *}$ & 0,0906255 & 0,0457461 & 1,98 & 0,048 & {$[0,0009648 ; 0,1802861]$} \\
\hline $\begin{array}{l}\text { Se já Investiu em } \\
\text { Renda Fixa** }\end{array}$ & 2,676874 & 1,167853 & 2,29 & 0,022 & {$[0,3879241 ; 4,965825]$} \\
\hline Constante** & $-4,761312$ & 1,870949 & $-2,54$ & 0,011 & {$[-8,428305 ;-1,094319]$} \\
\hline \multicolumn{6}{|c|}{ Log likelihood-22,800031 } \\
\hline LR chi2 (2) & 15,91 & & & & \\
\hline Prob $>$ chi 2 & 0,0004 & & & & \\
\hline Pseudo $\mathrm{R}^{2}$ & 0,2587 & & & & \\
\hline Área Embaixo RO & 0,7892 & & & & \\
\hline \multicolumn{6}{|c|}{ * Significante pelo menos a $10 \%$} \\
\hline \multicolumn{6}{|c|}{$* *$ Significante pelo menos a $5 \%$} \\
\hline \multicolumn{6}{|c|}{$* * *$ Significante pelo menos a $1 \%$} \\
\hline
\end{tabular}

Inicialmente, vale a pena mencionar que este também é um bom modelo preditivo, tendo em vista que a área embaixo da curva ROC foi de 78,92\%.

Analisando os resultados acima denotados, verifica-se que as variáveis idade e se o analista em questão já tinha investido em renda fixa para fins pessoais foram estatisticamente significativas (considerando uma probabilidade de erro do tipo I de 5\%).

Logo, calculando as Odds Ratio delas:

$$
\begin{aligned}
& e^{0,0906255}=1,094859 \\
& e^{2,676874}=14,53958
\end{aligned}
$$

Isto implica nas seguintes interpretações: a cada um ano a mais de idade, a chance de analista invocar a heurística da disponibilidade para seu processo decisório é 9,49\% maior. De modo complementar, um analista que já investiu em renda fixa para fins pessoais possui uma chance $1353,96 \%$ maior de utilizar a heurística da disponibilidade para tomar seu processo de tomada de decisão.

Os achados demonstram que na medida em que as pessoas vão ficando mais velhas, as experiências ruins tendem a ser mais persistentes, utilizando mais acentuadamente a heurística da disponibilidade. De modo não menos surpreendente, um indivíduo que investe em renda 
fixa tende a ser mais conservador. Logo, experiências ruins podem ter um efeito mais duradouro para um sujeito que já é naturalmente mais conservador.

É importante mencionar que todas essas análises são ceteris paribus e feitas na presença de todas as variáveis.

\subsubsection{Questão 6 - Profissionais de uma Grande Instituição Financeira Brasileira}

De modo análogo às questões 2 e 3, a questão 6 dessa tese também possuía duas versões. Conforme discussões a priori, seu objetivo era verificar se existia algum tipo de ancoragem às palavras lucro e prejuízo para um cenário onde o preço de uma dada ação tinha se comportado de modo idêntico.

Dos 28 analistas que responderam a versão ancorada no lucro, 14 (50,0\%) comprariam a ação dessa empresa, ao passo em que na versão ancorada no prejuízo, somente 9 (33,33\%) comprariam a mesma ação da empresa.

Essa estatística acima levantada pode sugerir de que os profissionais dessa IF possam sofrer algum tipo de ancoragem a essas palavras, mesmo em situações onde a variação do preço da ação é o mesmo.

Entretanto, a aplicação do teste de hipóteses de diferenças de proporções revela que a um nível de significância de 5\%, não existem indícios de que haja diferenças entre uma abstrata população de analistas dessa IF que responderia a versão onde há lucro e na que há prejuízo. Assumindo que a hipótese nula do teste seja de que a diferença é igual a 0, para a hipótese alternativa de que a diferença é diferente de 0 , obteve-se um p-value de 0,2103, o que explica o comentado acima. Vale a pena ressaltar que o $p$-value observado é relativamente pequeno, o que pode sugerir de que a variável versão da questão possa ainda assim fazer efeito.

Dessa maneira, verifica-se que todas as hipóteses relacionadas à ocorrência de algum tipo de ancoragem (hipóteses 4, 5 e 8) foram rejeitadas tanto para o universo de estudantes da FEA/USP quanto para os analistas da IF. 
Ainda assim, uma nova regressão logística foi feita com vistas a capturar se existia algum outro fator social ou de perfil de investimentos que explicasse os resultados obtidos. As variáveis explicativas foram:

\begin{tabular}{|l|l|l|}
\hline \multicolumn{1}{|c|}{$\begin{array}{c}\text { Conjunto de Variáveis Explicativas - Regressão } \\
\text { Logística (lucro x prejuízo) - Hip. 8- IF }\end{array}$} & Categorias da Variável ou Escala de Medida & Categoria de Referência \\
\hline Gênero & Feminino ou Masculino & Feminino \\
\hline Estado Civil & $\begin{array}{l}\text { Solteiro(a), Casado(a), Divorciado(a) ou } \\
\text { Viúvo(a) }\end{array}$ & Casado \\
\hline Idade & Dado em anos & \\
\hline Número de Filhos & & \\
\hline Categoria do curso em que se formou & $\begin{array}{l}\text { Ciências Sociais } \\
\text { Engenharia/Computação, Outros }\end{array}$ & Ciências Sociais Aplicadas \\
\hline Se já investiu em Renda Variável & Sim ou Não & Não \\
\hline Se já investiu em Renda Fixa & Sim ou Não & Não \\
\hline $\begin{array}{l}\text { Se usa as Informações Contábeis na Tomada de } \\
\text { Decisão }\end{array}$ & Sim ou Não & Não \\
\hline Versão do Questão 6 & Ancorada no Lucro ou no Prejuízo & Lucro \\
\hline Respondeu de acordo com a hipótese 1 & Sim ou Não & Não \\
\hline Respondeu de acordo com a hipótese 2 & Sim ou Não & Não \\
\hline Respondeu de acordo com a hipótese 3 & Sim ou Não & Não \\
\hline Respondeu de acordo com a hipótese 6 & Sim ou Não & Não \\
\hline Respondeu de acordo com a hipótese 7 & Sim ou Não & Não \\
\hline Respondeu de acordo com a hipótese 9 & Sim ou Não & Não \\
\hline Respondeu de acordo com a hipótese 10 & Sim ou Não & Não \\
\hline
\end{tabular}

Quadro 20 - Conjunto de Variáveis Explicativas - Regressão Logística - Hip. 8 (lucro x prejuízo)

- Instituição Financeira

O seguinte modelo foi obtido: 
Tabela 22 - Resultado da Regressão Logística - Hip. 8 (lucro x prejuízo) - Instituição Financeira

\begin{tabular}{|c|c|c|c|c|c|}
\hline & Coeficiente estimado & Erro Padrão & $\mathrm{Z}$ & $P$-value & $\begin{array}{c}\text { Intervalo de Confiança - } \\
95 \%\end{array}$ \\
\hline Hipótese 6-Sim** & $-1,632384$ & 0,6997469 & $-2,33$ & 0,020 & {$[-3,003863 ;-0,2609052]$} \\
\hline $\begin{array}{l}\text { Versão Ancorada } \\
\text { no Prejuízo** }\end{array}$ & -1.47162 & 0,7206083 & $-2,04$ & 0,041 & {$[-2,883987 ;-0,0592539]$} \\
\hline Hipótese 9-Sim* & $-1,579703$ & 0,7209226 & 0,028 & 0,028 & {$[-2,992685 ;-0,1667206]$} \\
\hline Constante*** & 2,23724 & 0,8058632 & 2,78 & 0,005 & {$[0,6577767 ; 3,816702]$} \\
\hline \multicolumn{6}{|c|}{$\begin{array}{ll}\text { Log likelihood } & -26,592501\end{array}$} \\
\hline Prob $>$ chi2 & 0,0007 & & & & \\
\hline Pseudo $\mathrm{R}^{2}$ & 0,2425 & & & & \\
\hline Área Embaixo ROC & 0,8090 & & & & \\
\hline \multicolumn{6}{|c|}{ * Significante pelo menos a $10 \%$} \\
\hline \multicolumn{6}{|c|}{$* *$ Significante pelo menos a $5 \%$} \\
\hline *** Significante pe & nos a $1 \%$ & & & & \\
\hline
\end{tabular}

Como se verifica, este modelo possui acentuado poder preditivo, dado que a área embaixo da curva ROC foi de $80,90 \%$. Entretanto, essa tese não possui como objetivo e criação de modelos preditivos.

Analisando o modelo acima denotado, verifica-se que três variáveis foram estatisticamente significativas a um nível de significância de 5\%, isto é, se o indivíduo incorreu no efeito de correlação ilusória, a versão da questão e se o sujeito também incorreu no uso da heurística da representatividade para responder a questão 7.

Conforme se vislumbra, a versão da questão foi estatisticamente significativa, o que implica que a versão da questão possa fazer diferença, contradizendo o teste de hipóteses de diferença de proporções. Entretanto, vale a pena lembrar que esse teste apresentou um $p$-value que chegou relativamente perto da zona de rejeição da hipótese nula, o que pode explicar o resultado acima obtido.

Calculando a Odds Ratio das variáveis em questão:

$$
\begin{aligned}
& e^{-1,632384}=0,195463 \\
& e^{-1,47162}=0,2295532 \\
& e^{-1,579703}=0,2060363
\end{aligned}
$$


Contudo, um analista que responde a versão ancorada na palavra "prejuízo" possui uma chance $77,04 \%$ menor de recomendar a compra da ação, fortalecendo a ideia de que a hipótese 8 talvez não deva ser refutada. Apesar do teste de hipóteses elaborado apontar o contrário, é importante lembrar que o tamanho da amostra foi pequeno, o que traz limitações na aplicação do mesmo.

Como se noticia, indivíduos que não viram o efeito de correlação ilusória possuem uma chance $80,45 \%$ menor de comprar a ação quando comparados aos que viram tal efeito. Adicionalmente, um indivíduo que usou a heurística da representatividade para responder a questão 7 também possui uma chance $79,40 \%$ menor de comprar essa ação quando comparado a um analista que não usou tal heurística. Esses fatos, per si, aparentemente não possuem muita relevância, dado que não há uma relação direta entre as variáveis com a questão 6. Contudo, um fenômeno interessante se manifestou: tanto a hipótese 6 quanto a hipótese 9 estão associadas a dificuldade de percepção de dois aspectos importantes do cálculo de probabilidades, isto é, a noção de correlação e a de independência. Assim sendo, os analistas que aparentam ter mais problemas no emprego de técnicas estatísticas em suas análises foram os mais conservadores ao responder a questão 6 .

Vale a pena ressaltar que todas as análises de Odds Ratio são ceteris paribus e considerando os efeitos na presença de todas as variáveis.

\subsubsection{Questão 7 - Profissionais de uma Grande Instituição Financeira Brasileira}

Conforme excertos anteriores, a questão 7 e sua respectiva hipótese 9 tinha como objetivo verificar se os respondentes faziam uso da heurística da representatividade para tomar suas decisões.

Do total de 55 respondentes, $24(43,64 \%)$ usaram a heurística da representatividade, desconsiderando a noção de independência matemática. Esse fato sugere que diferentemente dos alunos da FEA/USP, a hipótese 9 pode ser rejeitada para o universo de analistas dessa IF.

De fato, ao se aplicar o teste de hipóteses apropriado para $\mathrm{p}_{0}=0,5$ e $\mathrm{p}_{0}=0,75$, com as hipóteses alternativas $\mathrm{p}_{0}>0,5$ e $\mathrm{p}_{0}>0,75$, os $p$-values de ambos os testes foram de $0,8274 \mathrm{e}$ 
1,000 respectivamente. Logo, a hipótese 9 dessa tese é rejeitada para o universo de analistas da IF.

Tal como feito nos casos anteriores, uma regressão logística foi feita para identificar quais variáveis podem explicar o porquê de $43,64 \%$ dos analistas da IF terem utilizado a heurística da representatividade no seu processo decisório. O seguinte conjunto de variáveis foi empregado:

\begin{tabular}{|c|c|c|}
\hline $\begin{array}{c}\text { Conjunto de Variáveis Explicativas - Regressão } \\
\text { Logística - Hip. } 9 \text { (heurística da } \\
\text { representatividade)- IF }\end{array}$ & Categorias da Variável ou Escala de Medida & Categoria de Referência \\
\hline Gênero & Feminino ou Masculino & Feminino \\
\hline Estado Civil & $\begin{array}{l}\text { Solteiro(a), Casado(a), Divorciado(a) } \text { ou } \\
\text { Viúvo(a) }\end{array}$ & Casado \\
\hline Idade & Dado em anos & \\
\hline \multicolumn{3}{|l|}{ Número de Filhos } \\
\hline Categoria do curso em que se formou & $\begin{array}{l}\text { Ciências Sociais } \\
\text { Engenharia/Computação, Outros }\end{array}$ & Ciências Sociais Aplicadas \\
\hline Se já investiu em Renda Variável & Sim ou Não & Não \\
\hline Se já investiu em Renda Fixa & Sim ou Não & Não \\
\hline $\begin{array}{l}\text { Se usa as Informações Contábeis na Tomada de } \\
\text { Decisão }\end{array}$ & Sim ou Não & Não \\
\hline Respondeu de acordo com a hipótese 1 & Sim ou Não & Não \\
\hline Respondeu de acordo com a hipótese 2 & Sim ou Não & Não \\
\hline Respondeu de acordo com a hipótese 3 & Sim ou Não & Não \\
\hline Respondeu de acordo com a hipótese 6 & Sim ou Não & Não \\
\hline Respondeu de acordo com a hipótese 7 & Sim ou Não & Não \\
\hline Respondeu de acordo com a hipótese 10 & Sim ou Não & Não \\
\hline
\end{tabular}

Quadro 21 - Conjunto de Variáveis Explicativas - Regressão Logística - Hip. 9 (heurística da representatividade) - Instituição Financeira

Com isso, obteve-se o seguinte modelo: 
Tabela 23 - Resultado da Regressão Logística - Hip. 9 (heurística da representatividade) - Instituição Financeira

\begin{tabular}{|c|c|c|c|c|c|}
\hline & $\begin{array}{l}\text { Coeficiente } \\
\text { estimado }\end{array}$ & Erro Padrão & $\mathrm{z}$ & $P$-value & $\begin{array}{c}\text { Intervalo de Confiança - } \\
95 \%\end{array}$ \\
\hline Constante & $-0,1967103$ & 0,2814117 & $-0,70$ & 0,485 & {$[-0,7482671 ; 0,3548465]$} \\
\hline \multicolumn{6}{|c|}{ Log likelihood-35,105014 } \\
\hline LR chi2 $(0)$ & 0,00 & & & & \\
\hline \multicolumn{6}{|l|}{ Prob $>$ chi 2} \\
\hline Pseudo $\mathrm{R}^{2}$ & 0,0000 & & & & \\
\hline Área Embaixo ROC & 0,50 & & & & \\
\hline \multicolumn{6}{|c|}{ * Significante pelo menos a $10 \%$} \\
\hline \multicolumn{6}{|c|}{ ** Significante pelo menos a $5 \%$} \\
\hline$* * *$ Significante pelc & os a $1 \%$ & & & & \\
\hline
\end{tabular}

Como se percebe, o vetor de variáveis explicativas não foi capaz de mostrar o que levou esses analistas da IF a usarem a heurística da representatividade em seu processo decisório.

\subsubsection{Questão 8 - Profissionais de uma Grande Instituição Financeira Brasileira}

A hipótese 10 dessa tese (englobada na questão 8), conforme capítulo anterior, objetivava verificar se os respondentes possuíam algum tipo de dificuldade em noticiar o efeito de regressão à média.

Dos 55 respondentes, $36(65,45 \%)$ demonstraram ter dificuldades em noticiar o efeito de regressão a média, isto é, esses analistas deram um maior peso a última observação no seu processo de decisão e não comprariam a ação da empresa por se tratar de ponto de mínimo, o que sugere que a hipótese 10 não pode ser refutada no universo de analistas dessa IF, diferentemente do observado com os estudantes da FEA/USP.

De fato, ao se aplicar o teste de hipóteses apropriado para $\mathrm{p}_{0}=0,5$ e $\mathrm{p}_{0}=0,75$, com as hipóteses alternativas $\mathrm{p}_{0}>0,5$ e $\mathrm{p}_{0}>0,75$, os $p$-values de ambos os testes foram de 0,0109 e 0,9490 respectivamente. Desse modo, pode-se dizer que a verdadeira proporção de analistas dessa IF que não veriam o efeito de regressão a média é superior a $50 \%$, mas inferior a $75 \%$, o que confirma a intuição oriunda da estatística descritiva de que a hipótese 10 não pode ser refutada para os analistas dessa IF.

Com vistas a estimar o que levou a maioria desses analistas a se comportar desse modo, foi feita uma nova regressão logística com o seguinte conjunto de variáveis: 


\begin{tabular}{|l|l|l|}
\hline $\begin{array}{c}\text { Conjunto de Variáveis Explicativas - Regressão } \\
\text { Logística - Hip. 10 (regressão à média)- IF }\end{array}$ & Categorias da Variável ou Escala de Medida & Categoria de Referência \\
\hline Gênero & Feminino ou Masculino & Feminino \\
\hline Estado Civil & $\begin{array}{l}\text { Solteiro(a), Casado(a), Divorciado(a) ou } \\
\text { Viúvo(a) }\end{array}$ & Casado \\
\hline Idade & Dado em anos & \\
\hline Número de Filhos & & \\
\hline Categoria do curso em que se formou & $\begin{array}{l}\text { Ciências Aplicadas, } \\
\text { Engenharia/Computação, Outros }\end{array}$ & Ciências Sociais Aplicadas \\
\hline Se já investiu em Renda Variável & Sim ou Não & Não \\
\hline Se já investiu em Renda Fixa & Sim ou Não & Não \\
\hline $\begin{array}{l}\text { Se usa as Informações Contábeis na Tomada de } \\
\text { Decisão }\end{array}$ & Sim ou Não & Não \\
\hline Respondeu de acordo com a hipótese 1 & Sim ou Não & Não \\
\hline Respondeu de acordo com a hipótese 2 & Sim ou Não & Não \\
\hline Respondeu de acordo com a hipótese 3 & Sim ou Não & Não \\
\hline Respondeu de acordo com a hipótese 6 & Sim ou Não & Não \\
\hline Respondeu de acordo com a hipótese 7 & Sim ou Não & Não \\
\hline Respondeu de acordo com a hipótese 9 & Sim ou Não & Não \\
\hline
\end{tabular}

Quadro 22 - Conjunto de Variáveis Explicativas - Regressão Logística - Hip. 10 (regressão à média) - Instituição Financeira

Os seguintes resultados foram obtidos:

Tabela 24 - Resultado da Regressão Logística - Hip. 10 (regressão à média) - Instituição Financeira

\begin{tabular}{|c|c|c|c|c|c|}
\hline & Coeficiente estimado & Erro Padrão & $\mathrm{z}$ & $P$-value & $\begin{array}{c}\text { Intervalo de Confiança - } \\
95 \%\end{array}$ \\
\hline $\begin{array}{l}\text { Sexo } \\
\text { Masculino** }\end{array}$ & $-2,182927$ & 0,8636815 & $-2,53$ & 0,011 & {$[-3,875711 ;-0,4901421]$} \\
\hline $\begin{array}{l}\text { Se usa } \\
\text { Informações } \\
\text { Contábeis** }\end{array}$ & 1,735238 & 0,7720728 & 2,25 & 0,025 & {$[0,2220029 ; 3,248473]$} \\
\hline Constante** & 1,650869 & 0,7718329 & 2,14 & 0,032 & {$[0,1381245 ; 3,163654]$} \\
\hline \multicolumn{6}{|c|}{ Log likelihood-26,182927 } \\
\hline \multicolumn{6}{|l|}{ LR chi2 (2)13,85 } \\
\hline \multicolumn{6}{|l|}{ Prob $>$ chi $2 \quad 0,0010$} \\
\hline Pseudo $\mathrm{R}^{2}$ & 0,2092 & & & & \\
\hline Área Embaixo ROC & 0,7769 & & & & \\
\hline \multicolumn{6}{|c|}{ * Significante pelo menos a $10 \%$} \\
\hline \multicolumn{6}{|c|}{ ** Significante pelo menos a $5 \%$} \\
\hline$* * *$ Significante pelo & enos a $1 \%$ & & & & \\
\hline
\end{tabular}

Novamente, este modelo também é bom no quesito predição, dado que a área embaixo da curva ROC é de $77,69 \%$. 
A 95\% de confiança, o fato de o analista ser do sexo masculino e dele usar as informações contábeis em seu processo de tomada de decisão de investimentos individual foram estatisticamente significativos.

Calculando a Odds Ratio das variáveis em questão, tem-se que:

$e^{-2,182927}=0,1127112$

$e^{1,735238}=5,670276$

Dessa maneira, um indivíduo do sexo masculino tem uma chance $88,73 \%$ menor de não ver o efeito de regressão à média quando comparado a uma mulher. Esse resultado não surpreende, na medida em que mulheres tendem a ser mais conservadoras e por consequência, dão maior peso às informações negativas. Como o ponto de mínimo da série era o ponto mais recente, uma postura mais conservadora explicaria esse fenômeno relatado.

De modo complementar, um indivíduo que usa as informações contábeis para seu processo de tomada de decisão de investimentos individual possui uma chance 467,03\% maior de não ver o efeito de regressão à média e dar um peso maior a observação mais recente. Isso sugere que um usuário mais intenso das informações contábeis pode dar maior peso ao conteúdo informacional do último exercício societário em detrimento de uma concepção mais histórica.

\subsection{Compêndio dos Principais Resultados Obtidos}

A seguir, encontra-se tabela discriminando todos os principais resultados levantados junto às hipóteses de pesquisa dessa tese. 


\begin{tabular}{|c|c|c|c|}
\hline Hipótese & Descrição da Hipótese & $\begin{array}{c}\text { Foi Rejeitada para os } \\
\text { Estudantes da FEA/USP? }\end{array}$ & $\begin{array}{c}\text { Foi Rejeitada para os } \\
\text { Analistas da IF? }\end{array}$ \\
\hline Hipótese 1 & Efeito certeza & Sim & Sim \\
\hline Hipótese 2 & Efeito reflexão & Sim & Não \\
\hline Hipótese 3 & Efeito isolamento & Não & Não \\
\hline Hipótese 4 & $\begin{array}{l}\text { Ancoragem na perda } \mathrm{x} \\
\text { Ancoragem na não perda }\end{array}$ & Sim & Sim \\
\hline Hipótese 5 & $\begin{array}{l}\text { Ancoragem em números brutos } \\
\mathrm{x} \text { Ancoragem em números } \\
\text { relativos }\end{array}$ & Sim & Sim \\
\hline Hipótese 6 & Correlação ilusória & Não & Não \\
\hline Hipótese 7 & Heurística da disponibilidade & Não & Não \\
\hline Hipótese 8 & $\begin{array}{l}\text { Ancoragem no lucro } \mathrm{x} \\
\text { Ancoragem no prejuízo }\end{array}$ & Sim & Sim* \\
\hline Hipótese 9 & Heurística da representatividade & Não & Sim \\
\hline Hipótese 10 & Regressão à média & Sim & Não \\
\hline
\end{tabular}

Quadro 23 - Compêndio dos Principais Resultados

Como se vislumbra, a presença do efeito isolamento, da correlação ilusória e o uso da heurística da disponibilidade não foram refutados nem para o universo de estudantes da FEA/USP e nem para os profissionais analistas da instituição financeira em questão.

Isso fortalece a ideia de que estes vieses ou heurísticas possuem caráter mais holístico, isto é, tanto os alunos que ainda estão em formação quanto os profissionais propriamente ditos, incorreram nos vieses acima listados.

O efeito isolamento possui implicações práticas, na medida em que sugere que as decisões estão sendo tomadas de modo fragmentado. Isso sugere uma questão de caráter profissional: estariam as notas explicativas sendo interpretadas de modo desconexos uma com as outras?

Essa tese, pelas limitações metodológicas inerentes ao seu desenvolvimento, não permite com que asserções sejam estabelecidas de modo irrefutável. Contudo, não há como desprezar um fenômeno que parece ser persistente, na medida em que influencia estudantes e profissionais das duas instituições em estudo.

Não menos preocupante é a ilusão da correlação acima evidenciada. A mesma sugere que a simples forma como um resultado é evidenciado pode levar a interpretações que ferem as teorias de apreçamento de ativos. Seria esse um fenômeno que exigiria uma nova forma de 
apresentação dos resultados ou isso é algo que pode ser combatido com base em educação formal? Os indícios sugerem que mesmo a educação formal foi incapaz de suprir essas deficiências, isto é, mesmo alunos de uma das melhores escolas de negócio do Brasil feriram a noção de diversificação de investimentos. Não obstante, os próprios analistas de uma renomada instituição financeira também não conseguiram notar esse fato, mesmo que eles lidem com esse tipo de questão diariamente em seus estudos e atribuições profissionais.

O fato da heurística da disponibilidade ter sido empregada tanto pelos alunos quanto pelos profissionais também tem implicações profissionais e sociais importantes para a profissão de contador. A informação contábil acabou sendo relegada ao segundo plano para a maioria dos indivíduos, que preferiram relembrar da experiência negativa, ao invés de usar a informação de que os procedimentos de governança e gerenciamento de riscos já tinham sido tomados. Se a essência econômica fosse efetivamente respeitada, a informação contábil auditada não faria com que essa memória negativa persistisse na mente das pessoas. Neste caso, uma nova dúvida surge: em que situações o conjunto de informações contábeis é relegado ao segundo plano?

Outro aspecto que merece atenção diz respeito ao seguinte fenômeno: todas as hipóteses associadas ao efeito ancoragem foram refutadas nessa tese, tanto para os alunos da FEA/USP quanto para os analistas da IF. Diferentemente das constatações acima elucubradas, esses achados fortalecem a ideia de que a essência econômica prevalece sobre a forma, dado que a mudança da forma não resultou na mudança da forma como os usuários tomam sua decisão.

Surpreendentemente, diferente do propugnado pela Prospect Theory de Kahneman e Tversky, o efeito certeza não foi suficientemente observado para nenhum dos dois públicos estudados nessa tese, apesar de os questionários serem análogos em termos de formulação matemática. Entretanto, uma grande diferença foi observada na forma como eles foram elaborados: enquanto os trabalhos de Kahneman e Tversky faziam as questões de forma direta aos respondentes, essa tese fez as perguntas de forma indireta, fazendo uso de notas explicativas apresentadas e cenários hipotéticos. Logo, uma nova questão nasce: a mesmo questão, se for apresentada de modo indireto, pode produzir resultados diferentes?

Já no tocante ao efeito reflexão, um fenômeno interessante se materializou: o mesmo só foi evidenciado no universo dos analistas profissionais da instituição financeira em questão, 
denotando que o observado em pesquisas com alunos não necessariamente pode ser generalizado para os profissionais. Não obstante, a não negação do efeito reflexão para os profissionais assinala que estes possuem um perfil de investimento mais arriscado no campo das perdas, se comparado aos estudantes da FEA/USP.

De modo análogo, a maioria dos profissionais da IF não percebeu o efeito de regressão a média, também se comportando de maneira diferente dos estudantes. Isso implica em dizer que informações mais recentes possuem maior peso no processo decisório desses agentes. Logo, considerando que essa frase possa ser generalizável para os profissionais da IF, tem-se que o conjunto mais recente de informações contábeis possui um peso que pode superar todo o vetor de informações históricas, configurando-se como um processo estocástico com baixa memória.

Diferentemente do visto até então, a heurística da representatividade só possuiu efeitos estatisticamente significativos observados com os estudantes da FEA/USP, isto é, somente esse público alvo utilizou essa heurística de modo mais acentuado no seu processo decisório. Isto implica em dizer que os analistas da IF, talvez por possuírem mais experiência prática, analisem cada caso de modo individual, não considerando o todo. 


\section{Conclusões}

Esta tese buscou responder a seguinte pergunta de pesquisa: As heurísticas e os vieses influenciam 0 processo decisório dos indivíduos quando confrontados com demonstrações financeiras e contábeis publicadas pelas empresas?

Com vistas e obter indícios da resposta dessa questão, foram submetidos questionários junto aos estudantes da Faculdade de Economia, Administração e Contabilidade da Universidade de São Paulo e aos profissionais de uma grande instituição financeira.

Em linhas gerais, buscou-se verificar como as heurísticas da ancoragem, representatividade e disponibilidade geravam vieses e influenciavam o modo como os usuários tomam suas decisões utilizando informações de cunho contábil e financeiro.

Os resultados obtidos divergiram quando foram comparados os dois públicos estudados nessa tese: analistas de mercado de capitais e estudantes de uma das melhores faculdades de negócio do Brasil. Tal aspecto ajuda a contrapor a ideia de que o uso de estudantes pode ser uma proxy satisfatória para os profissionais analistas. Libby et al. (2002) alega que pesquisadores deveriam evitar profissionais ao menos que seja necessário para que se atinjam os propósitos da pesquisa. Essa tese defende justamente o contrário: se possível, deve-se sempre trabalhar com os analistas, na medida em que eles comportam de modo diferente aos estudantes.

Os resultados sugeriram que o uso da heurística da ancoragem não se mostrou significativa nem para os analistas e nem para os estudantes. Entretanto, o uso da heurística da disponibilidade se mostrou estatisticamente significativa, assim como a presença da noção de correlação ilusória e o efeito isolamento.

Por sua vez, o efeito reflexão e a não observação da regressão à média foram percebidos somente na amostra composta pelos analistas profissionais da instituição financeira. Finalmente, o uso da heurística da representatividade só teve efeito estatístico na presença dos alunos. 
Conforme discorrido a priori, a consecução da pesquisa possui algumas limitações, incluindo a seleção da amostra por conveniência e a dificuldade de se fazer pré-testes, dado que é um público muito ocupado com suas atribuições profissionais.

Ainda assim, não se pode refutar a conjectura elaborada pela tese, isto é, há indícios de que as heurísticas e os vieses influenciam o processo decisório dos indivíduos quando confrontados com dados oriundos das demonstrações financeiras e contábeis publicadas pelas empresas.

Essa situação realça que os órgãos elaboradores dos pronunciamentos técnicos devem considerar como os usuários tomam suas decisões propriamente ditas. A presença do efeito isolamento, por exemplo, pode sugerir pesquisas futuras que testem se a consecução de notas explicativas separadas facilita com que os usuários incorram em vieses em seus processos decisórios.

De modo complementar, a presença do uso da heurística da disponibilidade também possui impactos na atividade profissional do contador, pois sugere que a disponibilidade ou não de um conjunto de informação pode mudar a maneira como os usuários tomam suas decisões, relegando a informação contábil a um segundo plano, ou mesmo dando maior peso a mesma. Pesquisas futuras podem envolver quais são os critérios que levam certos tipos de informação a serem facilmente resgatadas cognitivamente pelos usuários em detrimento de outras.

A correlação ilusória também possui implicações, na medida em que ela realça a ideia que usar a informação contábil não consolidada pode ser misleading. O IASB já reconhece isso, na medida em que as demonstrações por IFRS necessariamente são feitas para o grupo econômico. Contudo, pesquisas futuras poderiam tentar identificar outros conjuntos de correlação ilusória que possam surgir, por exemplo, o relacionamento de uma conta com outra, levando os usuários inadvertidamente a decidirem com base em vieses.

A presença da não observação da regressão à média dentre os profissionais reafirma que as informações mais recentes possuem maior peso. Nesse sentido, uma pesquisa futura poderia tentar responder qual é o horizonte de tempo adequado que as informações contábeis devem abranger para dirimir possíveis vieses oriundos desse maior peso. 
De modo geral, os achados dessa tese confirmam a ideia de que os pressupostos da racionalidade econômica, muitas vezes, são insuficientes para explicar como as decisões são efetivamente tomadas. Logo, seus resultados favorecem a visão de Kahneman e Tversky.

Não obstante, ela enseja a visão do usuário da informação contábil, ressaltando suas limitações cognitivas naturais e de que modo isso pode influenciar o processo decisório. Assim sendo, os achados são úteis para quaisquer indivíduos que façam uso da informação contábil, na medida em que relatam armadilhas a que todos estão sujeitos.

As implicações profissionais que podem ser importantes para os órgãos reguladores estão explicitadas nos parágrafos anteriores dessa conclusão, sugerindo pesquisas futuras.

Como se verifica, espera-se que essa tese possa contribuir para que se fortaleça ainda mais a agenda de pesquisas em contabilidade comportamental, contribuindo para que haja uma relação mutualística entre a academia e a profissão contábil, de modo que as informações contábeis e financeiras produzidas pelos contadores possam ser cada vez mais utilizadas por diferentes stakeholders. 


\section{Referências}

Akerlof, G. A. (1970). The Market for "Lemons": Quality Uncertainty and the Market Mechanism. The Quarterly Journal of Economics, 84(3), 488-500.

Alghalith, M. (2010). Limitations of prospect theory and the expected utility theory: a new theory. Atlantic Economic Journal, 38(2). 243-244.

Alghalith, M. et al. (2012). Testing dominant theories and assumptions in behavior finance. The Journal of Risk Finance, 13(3), 262-268.

Anagol, S., \& Gamble, K. J. (2013). Does Presenting Investment Results Asset by Asset Lower Risk Taking?.Journal of Behavioral Finance, (14), 276-300.

Anderson, D. R., Sweeney, D. J., \& Williams, Thomas A. (2007). Estatística Aplicada à Administração e Economia. 2 ed. São Paulo: Cengage Learning.

Avgouleas, E. (2006). Cognitive Biases and Investor Protection Regulation an Evolutionary Approach. Recuperado em 27/01/2016: http://ssrn.com/abstract=1133214 ou http://dx.doi.org/10.2139/ssrn.1133214

Bailey, W. et al. Behavioral Biases of Mutual Fund Investors (2011). Journal of Financial Economics, 102(1), 1-27.

Baghestanian, S. et al. (2015). Peer Effects and Risk Sharing in Experimental Asset Markets. SAFE Working Paper No. 67. Recuperado em 27/01/2016: http://ssrn.com/abstract=2504541 ou http://dx.doi.org/10.2139/ssrn.2504541

Bahmanziari, T., \& Odom, M. D. Prospect Theory and Risky Choice in the Ecommerce Setting: Evidence of a Framing Effect. Academy of Accounting and Financial Studies Journal, 19(1). 85-106. 
Barreto, P. S. et al. (2013). Tomada de Decisão e Teoria dos Prospectos em Ambiente Contábil: Uma Análise com Foco no Efeito Framin. Revista de Gestão, Finanças e Contabilidade, 3(2), 61-79.

Bar-Hillel, M. (1973). On the Subjective Probability of Compound Events. Organizational Behavior \& Human Performance, (9). 396-406.

Barberis, N. et al. (1998). A model of investor sentiment. Journal of Financial Economics, 49(3), 307-343.

Barberis, N. C. (2013). Thirty Years of Prospect Theory in Economics: a Review and Assessment. Journal of Economic Perspectives, 27(1), 173-196.

Benakouche, T. (2001). Duas culturas, três culturas... ou redes? Dilemas da análise social da técnica. In: BAUMGARTEN, M.. (org.) A era do conhecimento: matrix ou ágora? Porto Alegre/Brasília: Ed. Universidade - UFRGS/Ed. Unb.

Berge, J., Dickhaut, J., \& McCabe, K. (1995).The individual versus the aggregate. In: R. H. Ashton,\& A. H. Ashton (Eds.), Judgment and decision-making research in accounting and auditing.102-134. New York: Cambridge.

Bovi, M. (2009). Economic versus psychological forecasting: evidence from consumer confidence surveys. Journal of Economic Psychology, 30(4), 563-574.

Brooks, R. (2012). Framing Contracts - Why Loss Framing Increases Effort. Yale Law \& Economics Research Paper No. 438.Journal of Institutional and Theoretical Economics (JITE), (168). 62-82.

Cason, T. N., \& Plott, C. R. (2014). Misconceptions and Game Form Recognition: Challenges to Theories of Revealed Preference and Framing. Journal of Political Economy, 122(6), 1235-1270. 
Cazzari, R. B. (2013). A compreensibilidade das informações contábeis e sua relação com os custos de transação sob a óptica dos profissionais de investimento. Dissertação de Mestrado, Departamento de Contabilidade e Atuária, Faculdade de Economia, Administração e Contabilidade, Universidade de São Paulo, São Paulo.

Chang, K. (2005). Prospect Theory or a Misuse of the Concept of Opportunity Cost? Recuperado em 27/01/2016: http://ssrn.com/abstract=687704 ou http://dx.doi.org/10.2139/ssrn.687704

Cohen, J. et al. (1972). A Confirmation of the Inertial- $\psi$ Effect in Sequential Choice and Decision. British Journal of Psychology, (63), 41-46.

Dantas, M. M., \& Macedo, M. A. S. (2013). O Processo Decisório no Ambiente Contábil: Um Estudo à Luz da Teoria dos Prospectos. Revista de Contabilidade e Controladoria, 5(3), 47-65.

DeBondt, W., \& Thaler, R. (1990). Do security analysts overreact? American Economic Review, 80(2), 52-57.

Decourt, R. F. et al. (2007). Behavioral Finance and the Investment Decision-Making Process in the Brazilian Financial Market. Recuperado em 27/01/2016: http://ssrn.com/abstract=960350 ou http://dx.doi.org/10.2139/ssrn.960350

Ebert, S., \& Wiesen, D. (2014). Joint measurement of risk aversion, prudence, and temperance. Journal of Risk and Uncertainty, 48(3), 231-252.

Einhorn, H. J., \& Hogarth, R. M. (1986).Decision making under ambiguity.Journal of Business, 59(4). S225-S250.

Erakar, S. E., \& Sox, H. C. (1981). Assessment of patients' preferences for therapeutic outcomes. Medical Decision Making, (1), 29-39.

Fama, E. F. (1970). Efficient capital markets: a review of theory and empirical work. Journal of Finance, 25(2), 383-417. 
Fávero, L. P. (2015). Análise de dados - Modelos de Regressão com EXCEL ${ }^{\circledR}$, STATA $^{\circledR} e$ $\operatorname{SPSS}^{\circledR}$. (1ed.). Rio de Janeiro: Elsevier.

Fischhoff, B. (1983). Predicting frames. Journal of Experimental Psychology: Learning, Memory and Cognition, (9), 103-116.

Fishburn, P. C., \& Kochenberger, G. A. (1979). Two-piece von Neumann-Morgenstern utility functions. Decision Sciences, (10), 503-518.

Frankel, R., \& Lee, C. (1998). Accounting valuation, market expectation, and cross-sectional stock returns. Journal of Accounting and Economics, 25(3), 283-319.

Gervais, S., \& Odean, T. (1997). Learning to be overconfident. Unpublished Working Paper, University of Pennsylvania.

Glaser, M. et al. (2007).Framing Effects in Stock Market Forecasts: The Difference between Asking for Prices and Asking for Returns. Review of Finance,11(2),325-357.

Goldsmith, K., \&Dhar, R. (2013). Negativity Bias and Task Motivation: Testing the Effectiveness of Positively versus Negatively Framed Incentives. Journal of Experimental Psychology: Applied, 19(4), 358-366.

Haubert, F. L. C. et al. (2012). Finanças Comportamentais: Um Estudo com Base na Teoria do Prospecto e no Perfil do Investidor de Estudantes de Cursos Stricto Sensu da Grande Florianópolis. Estratégia \& Negócios, 5(2), 171-199.

Haubert, F. L. C. (2014). Finanças Comportamentais: Uma Investigação com Base na Teoria do Prospecto e no Perfil do Investidor de Estudantes de Cursos Stricto Sensu Portugueses, Revista de Ciências da Administração, 16(38), 183-195.

Hershey, J. C., \& Schoemaker, P. J. H. (1980). Risk taking and problem context in the domain of losses: An expected-utility analysis. Journal of Risk and Insurance, (47), 111-132. 
Hoffmann, A. O. I., \& Fischer, T. (2010). Behavioral Aspects of Covered Call Writing: An Empirical Investigation. Journal of Behavioral Finance,13(1),66-79.

Hossain, T., \& List, J. (2012). The Behavioralist Visits the Factory: Increasing Productivity Using Simple Framing Manipulations. Journal Management Science, 58(12), 2151-2167.

Kahneman, D., \& Tversky, A. (1971). Belief in the law of small numbers. Psychological Bulletin. 76(2), 105-110.

Kahneman, D., \& Tversky, A. (1973a). Availability: A Heuristic for Judging Frequency and Probability. Cognitive Psychology. (5), 207-232.

Kahneman, D., \& Tversky, A. (1973b).On the psychology of prediction. Psychological Review, 80(4),237-251.

Kahneman, D., \& Tversky, A. (1979). Prospect Theory: an analysis of decision under risk. Econometrica, 47(2), 263-291.

Kahneman, D., \& Tversky, A. (1982a). On the study of statistical intuitions. Cognition, (11).123 -141. Elsevier Sequoia S.A., Lausanne.

Kahneman, D., \& Tversky, A. (1982b).Variants of uncertainty. Cognition, (11), 123 -141. Elsevier Sequoia S.A., Lausanne.

Kahneman, D., \& Tversky, A. (1983). Extensional Versus Intuitive Reasoning: The Conjunction Fallacy in Probability Judgement. Psychological Review, 90(4), 293-315.

Kahneman, D., \& Tversky, A. (1984).Choices, Values, and Frames. American Psychologist, 39(4), 341-350.

Kahneman, D., \& Tversky, A. (1986).Rational Choice and the Framing of Decisions. The Journal of Business, 59(4). Part 2: The Behavioral Foundations of Economic Theory. S251-S278. 
Kahneman, D., \& Tversky, A. (1992). Advances in Prospect Theory: Cumulative Representation of Uncertainty. Journal of Riskand Uncertainty. (5), 297-323.

Kahneman, D., \& Tversky, A. (1996) .On the Reality of Cognitive Illusions. Psychological Review, 103(3), 582-591.

Kerlinger, F. N. (1991). Metodologia da pesquisa em ciências sociais: um tratamento conceitual. 1 ed. São Paulo: EPU/EDUSP.

Köche, J. C. (1997). Ciência e Método: Uma Visão Histórica. In KÖCHE, J. C.; Fundamentos da metodologia científica: teoria da ciência e prática da pesquisa. Petrópolis: Vozes.

Kudryavtsev, A., \& Pavlodsky, J. (2012). Description-based and experience-based decisions: individual analysis. Judgement and Decision Making, 7(3), 316-331.

Kumar, A., \& Lim, S. S. (2008). How Do Decision Frames Influence the Stock Investment Choices of Individual Investors? Management Science, 54(6), 1052-1064.

Kwiatkowski, D. et al. (1992). Testing the null hypothesis of stationarity against the alternative of a unit root: How sure are we that economic time series have a unit root? Journal of Econometrics, 54(1-3),159-178.

Lee, A. Y., \& Aaker, J. (2004). Bringing the Frame into Focus: The Influence of Regulatory Fit on Processing Fluency and Persuasion. Journal of Personality and Social Psychology, 86(2), 205-218.

Libby, R. et al. (2002). Experimental research in financial accounting.Accounting, Organizations and Society, 775-810.

Liu, Y. et al. (2014). Prospect Theory for Online Financial Trading. PLoS 9 (10): e109458. Recuperado em 27/01/2016: http://dx.doi.org/10.1371/journal.pone.0109458. 
Maines, L. A. (1995). Judgment and decision-making research in financial accounting: a review and analysis. In R. H. Ashton, \& A.H Ashton (Eds.), Judgment and decisionmaking research in accounting and auditing,76-101. New York: Cambridge.

Martins, G. A., \& Theóphilo, C. R. (2007). Metodologia da Investigação Científica para Ciências Sociais Aplicadas. 1. ed. São Paulo: Atlas.

McQuail, D. (1994). Mass communication theory: An introduction. 3rd. Thousand Oaks, CA: Sage

Morin, E. (1996). Ciência com Consciência. Rio de Janeiro: Bertrand Brasil.

Newton-Smith, W. H. (1997). Popper, Ciência e Racionalidade. In: O’HEAR, Anthony (org). Karl Popper: Filosofia e Problemas. São Paulo: Ed. UNESP.

Odean, T. (1998).Volume, volatility, price, and profit when all traders are above average. Journal of Finance, 53(6), 1887-1934.

Packin, N. G. (2013). It's (Not) All About the Money: Using Behavioral Economics to Improve Regulation of Risk Management in Financial Institutions. University of Pennsylvania Journal of Business Law, 2(15).419-482.

Payne, J. W. et al. (1980). Translation of gambles and aspiration level effects in risky choice behavior. Management Science, (26), 1039-1060.

Rabin, M., \& Weizsacker, G. (2007). Narrow Bracketing and Dominated Choices. The American Economic Review, 99(4), 1508-1543.

Scheufele, D. A. (1999).Framing as a Theory of Media Effects. Journal of Communication, Winter. 103-122.

Silva, R. F. M. (2009). Finanças Comportamentais: um estudo comparativo utilizando a teoria dos prospectos com os alunos de graduação do curso de ciências contábeis. Revista Brasileira de Gestão de Negócios, 11(33), 383-403. 
Simon, H. A. (1957). Models of man. New York: Wiley.

Sloan, R. (1996). Do stock prices fully reflect information in accruals and cash flows about future earnings. The Accounting Review, 71(3), 289-315.

Slovic, P. et al. (1982). Response mode, framing and information-processing effects in risk assessment. In: R. Hogarth (Ed.), New directions for methodology of social and behavioral science: Question framing and response consistency. (pp. 21-36). San Francisco: JosseyBass.

Swaminathan, B., \& Lee, C. (2000). Do stock prices overreact to earnings news? Working Paper, Cornell University.

Tversky, A. (1977). On the elicitation of preferences: Descriptive and prescriptive considerations. In D. Bell. R. L. Kenney, \& H. Raiffa (Eds.), Conflicting objectives in decisions. International Series on Applied Systems Analysis (pp. 209-222). New York: Wiley.

Tversky, A., \& Kahneman, D. (1974). Judgment under uncertainty: heuristics and biases. Science.(185), 1124-1131.

Tversky, A., \& Kahneman, D. (1981).The Framing of Decisions and the Psychology of Choice. Science. (211), 454-458.

Verhaeghe, J. et al. O saber nas ciências humanas. (2010). In: VERHAEGHE, Jean-Claude et al. Praticar a Epistemologia - Um Manual de Iniciação para Professores e Formadores. São Paulo: Loyola.

Versluis, C. et al. (2010). A Cumulative Prospect Theory Approach to Option Pricing. Recuperado em 27/01/2016: http://ssrn.com/abstract=1717015 orhttp://dx.doi.org/10.2139/ssrn.1717015 
Von Neumann, J., \& Morgenstern, O. (1947). Theory of Games and Economic Behavior 2 ed. Princeton University Press.

Yoshinaga, C. E., \& Ramalho, T. B. (2014). Finanças Comportamentais no Brasil: uma aplicação da teoria da perspectiva em potenciais investidores. Revista Brasileira de Gestão de Negócios, 16(53), 594-615. 
Apêndice 1 - Versão 1 do Questionário Submetido aos Alunos de Graduação da Faculdade Economia, Administração e Contabilidade da Universidade de São Paulo

\section{Questionário}

Prezado Aluno, meu nome é Roberto Bomgiovani Cazzari e sou discente do programa de doutorado em Controladoria e Contabilidade da FEA/USP. Se possível, gostaria de contar com a sua colaboração respondendo ao questionário abaixo. É importante salientar que a pesquisa versa sobre processo de tomada de decisão com base na divulgação de informações contábeis e financeiras. Agradeço desde já pela colaboração.

\section{$\underline{\text { Parte } 1 \text { - Perfil Acadêmico e Social }}$}

\section{Gênero:}

( ) Masculino

( ) Feminino

\section{Estado Civil:}
( ) Solteiro(a)
( ) Casado(a)/ Em União Estável
( ) Divorciado(a)
( ) Viúvo(a)

Idade:

Quantos Filhos(as) você Possui?
( ) Nenhum
( ) 1
( ) 2
( ) 3
( ) 4
( ) 5 ou Mais

Curso:

Mês/Ano de Ingresso no Curso:

Mês/Ano de Previsão de Formatura:

Estagia ou Trabalha?
( ) $\mathrm{Sim}$
( ) Não
Se sim, há quanto tempo?

Participa ou já participou de Projeto de Iniciação Científica?
() $\mathrm{Sim}$
( ) Não

Se sim, quando?

Possui outra Formação?
( ) $\mathrm{Sim}$
( ) Não 
Se sim, qual?

\section{Parte 2 - Perfil de Decisão}

Observação: Todos os demonstrativos financeiros ressaltados nesse questionário foram publicados em IFRS.

\section{Questão 1}

Suponha que no papel de um analista de mercado de capitais, você esteja passando por dois problemas concomitantemente. Em ambos, você recomendou a compra de ações para um mesmo cliente. Agora que as demonstrações contábeis foram divulgadas, você se deparou com novos dados.

\section{Decisão 1:}

Em 31 de Dezembro de 2014, seu cliente, sob sua recomendação adquiriu 100 ações ordinárias da Seguradora B que trabalha com grandes riscos a um preço estipulado em R\$ 35,00 cada uma. Para tanto, você se baseou em análises de mercado que sugeriam que o preço da ação iria crescer. Após a divulgação, em abril de 2015, das demonstrações contábeis referentes ao exercício de 2014, a Seguradora B apresentou um lucro sem precedentes na história da companhia, o que fez com que o preço de sua ação ordinária aumentasse para $\mathrm{R} \$$ 45,00. A seguir, encontra-se a nota explicativa divulgada pela Seguradora B que trata dos passivos contingentes e um trecho de uma reportagem obtida em um jornal econômico de grande circulação.

\section{Nota Explicativa da Seguradora B}

Os Passivos Contingentes da Seguradora $\mathrm{B}$ realçam riscos potencias no tocante às ações cíveis, trabalhistas e fiscais nas quais o grupo econômico está submetido.

Não foram reconhecidos contabilmente os valores envolvidos em uma ação civil movida por um cliente contra a seguradora, devido ao indeferimento do pagamento de sinistro por suposto uso de má-fé do cliente. A avaliação jurídica da empresa estimou que o risco total seja de aproximadamente $40 \%$ do Patrimônio Líquido, porém o mesmo é remoto, sendo que sua probabilidade de não ocorrência é de $90 \%$.

\section{Trecho do Jornal Econômico}

A Seguradora B apresentou ontem o seu maior lucro líquido divulgado em toda a história da companhia. Analistas esperam que o atual exercício seja de grande bonança, o que poderia elevar o preço de sua ação ordinária para $\mathrm{R} \$ 55,00$ até o final de ano. Apesar de tudo, a ação civil movida pelo cliente $X$ pode levar o preço da ação à $\mathrm{R} \$ 30,00$, o que seria um desastre para os atuais possuidores do papel.

Com base nos textos acima retratados, você recomendaria a venda da ação agora ou no final do ano?
( ) Agora
( ) Final do Ano 


\section{Decisão 2:}

Para o exercício findo em 31 de Dezembro de 2014, a Empresa C apresentou um prejuízo de R\$ 300 (em milhões de reais), o que trouxe desconfiança a todo o mercado, tendo em vista que foi o primeiro ano em que a empresa apresentou prejuízo. Após análise detalhada das demonstrações contábeis publicadas em IFRS, você notou que isso se devia à desvalorização dos ativos financeiros disponíveis a venda pela entidade.

Não obstante, você percebeu que historicamente, em 10\% dos casos, os ativos financeiros mantidos a valor justo sofriam grandes valorizações. Logo as estimativas apontavam que se isso acontecesse novamente, o lucro líquido do próximo período seria de R\$100 (em milhões de reais). Caso contrário, o prejuízo poderia ser ainda maior, atingindo os $\mathrm{R} \$ 500$ (em milhões de reais).

Como profissional de investimentos de uma grande corretora, você tinha recomendado a compra da ação da empresa dois meses atrás para um grande cliente. Infelizmente, o mesmo acabou por perder dinheiro, dado a subsequente desvalorização dos títulos mobiliários da Empresa $\mathrm{C}$ após a divulgação de seus resultados. Na época da compra da ação, seu preço era $\mathrm{R} \$ 20,00$. Após a divulgação dos resultados, o preço da ação foi para $\mathrm{R} \$ 10,00$ e caso as estimativas pessimistas se confirmarem, poderá valer $\mathrm{R} \$ 2,00$. Na visão otimista, a mesma passaria a valer $\mathrm{R} \$ 25,00$.

O que você recomendaria ao cliente?

( ) Que ele as vendesse imediatamente

( ) Que ele mantivesse as ações até o final do ano

\section{Questão 2}

Em 31 de dezembro de 2015, o Patrimônio Líquido da Empresa A (setor de varejo) totalizava $\mathrm{R} \$ 1.000$ (em milhões de reais). Abaixo, encontra-se transcrita a nota explicativa de risco de mercado da Empresa A.

\section{Nota Explicativa - Empresa A}

O risco de mercado é o risco de que o valor justo ou os fluxos de caixa futuros de instrumento financeiro oscilem devido a mudanças nos preços de mercado. $O$ risco de mercado compreende três tipos de risco: o risco da moeda, da taxa de juros e outros riscos de preços.

A gestão de risco do mercado da Empresa A objetiva minimizar a exposição do grupo aos diferentes riscos em que os instrumentos financeiros acabam por gerar, tais como exposição cambial e de taxa de juros.

As análises do risco de mercado são feitas através dos seguintes procedimentos:

- Estimação do Valor em Risco (VaR): considera a perda econômica potencial máxima a que a entidade está submetida, dado um intervalo de tempo e um nível de confiança previamente adotados;

- VaR Estressado: medida obtida do VaR que considera cenários de extrema volatilidade; 
- Teste de Estresse: simulações efetuadas para se verificar como diferentes ativos e passivos reagem às situações em que variáveis de mercado se comportam de modo extremado.

Com base nas estimativas estatísticas realizadas, verificou-se que para o próximo ano, a um nível de confiança de 95\%, pode-se dizer que o VaR de todo a Empresa é de R $\$ 100$ (em milhões de reais), isto é, somente em 5\% dos casos que ela perderá mais do que R\$100 (em milhões de reais).

Com base unicamente nessas informações, você recomendaria a compra da ação dessa empresa?

( ) $\operatorname{Sim}$

( ) Não

\section{Questão 3}

Abaixo, encontra-se versão resumida do balanço patrimonial divulgado pela Empresa D (setor de varejo) para o último exercício societário:

Empresa D

Balanço Patrimonial Consolidado

(Em milhões de Reais)

\begin{tabular}{|l|c|l|c|}
\hline & $31 / 12 / 2015$ & & $31 / 12 / 2015$ \\
\hline Ativo Circulante & 5.500 & Passivo Circulante & 4.500 \\
\hline & & & \\
\hline $\begin{array}{l}\text { Ativo Realizável a } \\
\text { Longo Prazo }\end{array}$ & 500 & $\begin{array}{l}\text { Passivo Exigível a } \\
\text { Longo Prazo }\end{array}$ & 1.500 \\
\hline & & & \\
\hline & 800 & & \\
\hline Imobilizado & 100 & Patrimônio Líquido & 900 \\
\hline Intangível & & & 6.900 \\
\hline
\end{tabular}

Recentemente o diretor financeiro da empresa D buscou contato com o Banco no qual você trabalha para discutir sobre a possibilidade de receber um financiamento de $\mathrm{R} \$ 4500$ (em milhões de reais) para ser quitado em 12 parcelas no próximo ano. Supondo que você seja o responsável por tomar essa decisão, você aprovaria o empréstimo?
() $\mathrm{Sim}$
( ) Não

\section{Questão 4}

No último exercício societário, o Banco E apresentou um lucro nunca antes visto na história do país. Abaixo, encontra-se discriminada a Demonstração de Resultados do último exercício: 
Banco E

Demonstração dos Resultados

(Em milhões de Reais)

\begin{tabular}{|l|c|}
\hline & De 01/01/2015 a 31/12/2015 \\
\hline Recita de Juros e Rendimentos & 5.000 \\
\hline Despesa de Juros e Rendimentos & $(2.500)$ \\
\hline Receita de Serviços & 3.100 \\
\hline Resultado com Operações de Seguros & 2.400 \\
\hline Despesas Gerais e Administrativas & $(1.000)$ \\
\hline Despesas Tributárias & $(1.500)$ \\
\hline $\begin{array}{l}\text { Resultado de Participação sobre o Lucro } \\
\text { Líquido da Seguradora F }\end{array}$ & 4.000 \\
\hline Imposto de Renda e Contribuição Social & $(3230)$ \\
\hline Lucro Líquido & 6.270 \\
\hline
\end{tabular}

Suponha que você trabalhe em uma grande corretora. Recentemente, um importante cliente no qual você recomendou a compra das ações do Banco E veio te procurar perguntando se você achava interessante que ele comprasse as ações da Seguradora F como forma de garantir um lucro no resultado com ações no próximo período. Você sugeriria essa compra?

( ) $\mathrm{Sim}$

( ) Não

\section{Questão 5}

Suponha que há 2 anos, uma grande empresa mineradora se envolveu em um grave caso de corrupção. Após medidas terem sido tomadas e seus demonstrativos contábeis republicados, a empresa apresentou lucro no último exercício social.

Na nota explicativa que versa sobre os riscos nos quais a entidade está submetida, encontra-se transcrito trecho abaixo que versa sobre os riscos operacionais:

\section{Trecho da Nota Explicativa}

"Conforme as boas práticas de governança e gerenciamento de riscos, a Mineradora G possui estrutura para que estes sejam efetivamente identificados, mensurados, avaliados e reportados. Para tanto, existem uma série de órgãos responsáveis..."

Com base na informação acima transcrita, você compraria uma ação dessa empresa?
() $\operatorname{Sim}$
( ) Não

\section{Questão 6}

Suponha que ao final do ano passado, você tenha comprado 2 ações da Empresa $\mathrm{H}$ ao preço de R \$ 5,00 cada uma. Após a divulgação das Demonstrações Contábeis do último exercício, a 
empresa apresentou um lucro um pouco abaixo do esperado pelo mercado, o que fez com que o preço da ação caísse para $\mathrm{R} \$ 4,00$. Você ainda compraria outra ação dessa empresa?

( ) $\mathrm{Sim}$

( ) Não

\section{Questão 7}

O Banco I constituiu uma estimativa para perdas com Créditos de Liquidação Duvidosa no valor de R\$ 1000 (em milhões de reais). Após análise da nota explicativa que versa sobre o tema, verificou-se que todos esses créditos vão vencer durante o próximo exercício societário e que estes são compostos por 100 clientes independentes entre si com igual probabilidade de cada um entrar em uma situação de inadimplência.

Suponha que você trabalhe na área de crédito do referido banco. Após estudos internos realizados, o Banco I decidiu propor uma renegociação da dívida para os clientes. Estudos anteriores revelaram que $60 \%$ dos clientes aceitam renegociar suas dívidas. Para tanto, o Banco I já ligou para 10 clientes. Destes, somente o segundo cliente não aceitou os novos termos da negociação. Sabe-se que o $11^{\circ}$ cliente é do mesmo setor que o segundo cliente e vem passando por situação financeira análoga. Em sua opinião, este cliente:

( ) Aceitará a nova proposta de renegociação dos termos da dívida

( ) Não aceitará a nova proposta de renegociação dos termos da dívida

\section{Questão 8}

Suponha que você tenha compilado os resultados dos últimos dez exercícios da Empresa J. Não obstante, o preço da ação apresentou uma correlação de 0,96 com o Resultado do Exercício. Abaixo, encontram-se os mesmos discriminados:

\begin{tabular}{|c|c|}
\hline Exercício & $\begin{array}{c}\text { Resultado do Exercício (em milhões de } \\
\text { Reais) }\end{array}$ \\
\hline $01 / 01 / 2015$ a 31/12/2015 & 400 \\
\hline $01 / 01 / 2014$ a 31/12/2014 & 650 \\
\hline $01 / 01 / 2013$ a 31/12/2013 & 700 \\
\hline $01 / 01 / 2012$ a 31/12/2012 & 900 \\
\hline $01 / 01 / 2011$ a 31/12/2011 & 800 \\
\hline $01 / 01 / 2010$ a 31/12/2010 & 680 \\
\hline $01 / 01 / 2009$ a 31/12/2009 & 700 \\
\hline $01 / 01 / 2008$ a 31/12/2008 & 600 \\
\hline $01 / 01 / 2007$ a 31/12/2007 & 500 \\
\hline $01 / 01 / 2006$ a 31/12/2006 & 800 \\
\hline
\end{tabular}

Com base unicamente nas informações acima, você compraria a ação dessa empresa?

( ) $\mathrm{Sim}$

( ) Não

Caso desejar, deixe-me seu e-mail para que eu possa enviar os achados de minha pesquisa quando a mesma estiver finalizada.

E-mail:

Agradeço a atenção. 
Apêndice 2 - Versão 2 do Questionário Submetido aos Alunos de Graduação da Faculdade Economia, Administração e Contabilidade da Universidade de São Paulo

\section{Questionário}

Prezado Aluno, meu nome é Roberto Bomgiovani Cazzari e sou discente do programa de doutorado em Controladoria e Contabilidade da FEA/USP. Se possível, gostaria de contar com a sua colaboração respondendo ao questionário abaixo. É importante salientar que a pesquisa versa sobre processo de tomada de decisão com base na divulgação de informações contábeis e financeiras. Agradeço desde já pela colaboração.

\section{$\underline{\text { Parte } 1 \text { - Perfil Acadêmico e Social }}$}

\section{Gênero:}
( ) Masculino

( ) Feminino

\section{Estado Civil:}
( ) Solteiro(a)
( ) Casado(a)/ Em União Estável
( ) Divorciado(a)
( ) Viúvo(a)

Idade:

Quantos Filhos(as) você Possui?
( ) Nenhum
( ) 1
( ) 2
( ) 3
( ) 4
( ) 5 ou Mais

\section{Curso:}

Mês/Ano de Ingresso no Curso:

Mês/Ano de Previsão de Formatura:

Estagia ou Trabalha?
( ) $\mathrm{Sim}$
( ) Não
Se sim, há quanto tempo?

Participa ou já participou de Projeto de Iniciação Científica?

( ) Sim

( ) Não

Se sim, quando?

Possui outra Formação?

( ) $\mathrm{Sim}$ 
( ) Não

Se sim, qual?

\section{$\underline{\text { Parte } 2 \text { - Perfil de Decisão }}$}

Observação: Todos os demonstrativos financeiros ressaltados nesse questionário foram publicados em IFRS.

\section{Questão 1}

Suponha que no papel de um analista de mercado de capitais, você esteja passando por dois problemas concomitantemente. Em ambos, você recomendou a compra de ações para um mesmo cliente. Agora que as demonstrações contábeis foram divulgadas, você se deparou com novos dados.

\section{Decisão 1:}

Em 31 de Dezembro de 2014, seu cliente, sob sua recomendação adquiriu 100 ações ordinárias da Seguradora $\mathrm{B}$ que trabalha com grandes riscos a um preço estipulado em $\mathrm{R} \$$ 35,00 cada uma. Para tanto, você se baseou em análises de mercado que sugeriam que o preço da ação iria crescer. Após a divulgação, em abril de 2015, das demonstrações contábeis referentes ao exercício de 2014, a Seguradora B apresentou um lucro sem precedentes na história da companhia, o que fez com que o preço de sua ação ordinária aumentasse para R\$ 45,00. A seguir, encontra-se a nota explicativa divulgada pela Seguradora B que trata dos passivos contingentes e um trecho de uma reportagem obtida em um jornal econômico de grande circulação.

\section{Nota Explicativa da Seguradora B}

Os Passivos Contingentes da Seguradora B realçam riscos potencias no tocante às ações cíveis, trabalhistas e fiscais nas quais o grupo econômico está submetido.

Não foram reconhecidos contabilmente os valores envolvidos em uma ação civil movida por um cliente contra a seguradora, devido ao indeferimento do pagamento de sinistro por suposto uso de má-fé do cliente. A avaliação jurídica da empresa estimou que o risco total seja de aproximadamente $40 \%$ do Patrimônio Líquido, porém o mesmo é remoto, sendo que sua probabilidade de não ocorrência é de $90 \%$.

\section{Trecho do Jornal Econômico}

A Seguradora B apresentou ontem o seu maior lucro líquido divulgado em toda a história da companhia. Analistas esperam que o atual exercício seja de grande bonança, o que poderia elevar o preço de sua ação ordinária para $\mathrm{R} \$ 55,00$ até o final de ano. Apesar de tudo, a ação civil movida pelo cliente $\mathrm{X}$ pode levar o preço da ação à $\mathrm{R} \$ 30,00$, o que seria um desastre para os atuais possuidores do papel.

Com base nos textos acima retratados, você recomendaria a venda da ação agora ou no final do ano?
( ) Agora
( ) Final do Ano 


\section{Decisão 2:}

Para o exercício findo em 31 de Dezembro de 2014, a Empresa C apresentou um prejuízo de R\$ 300 (em milhões de reais), o que trouxe desconfiança a todo o mercado, tendo em vista que foi o primeiro ano em que a empresa apresentou prejuízo. Após análise detalhada das demonstrações contábeis publicadas em IFRS, você notou que isso se devia à desvalorização dos ativos financeiros disponíveis a venda pela entidade.

Não obstante, você percebeu que historicamente, em 10\% dos casos, os ativos financeiros mantidos a valor justo sofriam grandes valorizações. Logo as estimativas apontavam que se isso acontecesse novamente, o lucro líquido do próximo período seria de R\$100 (em milhões de reais). Caso contrário, o prejuízo poderia ser ainda maior, atingindo os $\mathrm{R} \$ 500$ (em milhões de reais).

Como profissional de investimentos de uma grande corretora, você tinha recomendado a compra da ação da empresa dois meses atrás para um grande cliente. Infelizmente, o mesmo acabou por perder dinheiro, dado a subsequente desvalorização dos títulos mobiliários da Empresa $\mathrm{C}$ após a divulgação de seus resultados. Na época da compra da ação, seu preço era $\mathrm{R} \$ 20,00$. Após a divulgação dos resultados, o preço da ação foi para $\mathrm{R} \$ 10,00$ e caso as estimativas pessimistas se confirmarem, poderá valer $\mathrm{R} \$ 2,00$. Na visão otimista, a mesma passaria a valer $\mathrm{R} \$ 25,00$.

O que você recomendaria ao cliente?

( ) Que ele as vendesse imediatamente

( ) Que ele mantivesse as ações até o final do ano

\section{Questão 2}

Em 31 de dezembro de 2015, o Patrimônio Líquido da Empresa A (setor de varejo) totalizava $\mathrm{R} \$ 1.000$ (em milhões de reais). Abaixo, encontra-se transcrita a nota explicativa de risco de mercado da Empresa A.

\section{Nota Explicativa - Empresa A}

O risco de mercado é o risco de que o valor justo ou os fluxos de caixa futuros de instrumento financeiro oscilem devido a mudanças nos preços de mercado. $O$ risco de mercado compreende três tipos de risco: o risco da moeda, da taxa de juros e outros riscos de preços.

A gestão de risco do mercado da Empresa A objetiva minimizar a exposição do grupo aos diferentes riscos em que os instrumentos financeiros acabam por gerar, tais como exposição cambial e de taxa de juros.

As análises do risco de mercado são feitas através dos seguintes procedimentos:

- Estimação do Valor em Risco (VaR): considera a perda econômica potencial máxima a que a entidade está submetida, dado um intervalo de tempo e um nível de confiança previamente adotados;

- VaR Estressado: medida obtida do VaR que considera cenários de extrema volatilidade; 
- Teste de Estresse: simulações efetuadas para se verificar como diferentes ativos e passivos reagem às situações em que variáveis de mercado se comportam de modo extremado.

Com base nas estimativas estatísticas realizadas, verificou-se que para o próximo ano, a um nível de significância de 5\%, pode-se dizer que o VaR de todo a Empresa é de R $\$ 100$ (em milhões de reais), isto é, em 95\% dos casos, o banco não perderá mais do que R\$100 (em milhões de reais).

Com base unicamente nessas informações, você recomendaria a compra da ação dessa empresa?

( ) $\operatorname{Sim}$

( ) Não

\section{Questão 3}

Abaixo, encontra-se versão resumida do balanço patrimonial divulgado pela Empresa D (setor de varejo) para o último exercício societário:

Empresa D

Balanço Patrimonial Consolidado

(Em milhões de Reais)

\begin{tabular}{|l|c|l|c|}
\hline & $31 / 12 / 2015$ & & $31 / 12 / 2015$ \\
\hline Ativo Circulante & 5.500 & Passivo Circulante & 4.500 \\
\hline & & & \\
\hline $\begin{array}{l}\text { Ativo Realizável a } \\
\text { Longo Prazo }\end{array}$ & 500 & $\begin{array}{l}\text { Passivo Exigível a } \\
\text { Longo Prazo }\end{array}$ & 1.500 \\
\hline & & & \\
\hline & 800 & & \\
\hline Imobilizado & 100 & Patrimônio Líquido & 900 \\
\hline Intangível & & & 6.900 \\
\hline
\end{tabular}

Recentemente o diretor financeiro da empresa D buscou contato com o Banco no qual você trabalha para discutir sobre a possibilidade de receber um financiamento na ordem de 5 vezes o Patrimônio Líquido para ser quitado em 12 parcelas no próximo ano. Supondo que você seja o responsável por tomar essa decisão, você aprovaria o empréstimo?
( ) $\mathrm{Sim}$
( ) Não

\section{Questão 4}

No último exercício societário, o Banco E apresentou um lucro nunca antes visto na história do país. Abaixo, encontra-se discriminada a Demonstração de Resultados do último exercício: 
Demonstração dos Resultados

(Em milhões de Reais)

\begin{tabular}{|l|c|}
\hline & De 01/01/2015 a 31/12/2015 \\
\hline Recita de Juros e Rendimentos & 5.000 \\
\hline Despesa de Juros e Rendimentos & $(2.500)$ \\
\hline Receita de Serviços & 3.100 \\
\hline Resultado com Operações de Seguros & 2.400 \\
\hline Despesas Gerais e Administrativas & $(1.000)$ \\
\hline Despesas Tributárias & $(1.500)$ \\
\hline $\begin{array}{l}\text { Resultado de Participação sobre o Lucro } \\
\text { Líquido da Seguradora F }\end{array}$ & 4.000 \\
\hline Imposto de Renda e Contribuição Social & $(3230)$ \\
\hline Lucro Líquido & 6.270 \\
\hline
\end{tabular}

Suponha que você trabalhe em uma grande corretora. Recentemente, um importante cliente no qual você recomendou a compra das ações do Banco E veio te procurar perguntando se você achava interessante que ele comprasse as ações da Seguradora F como forma de garantir um lucro no resultado com ações no próximo período. Você sugeriria essa compra?

( ) $\mathrm{Sim}$

( ) Não

\section{Questão 5}

Suponha que há 2 anos, uma grande empresa mineradora se envolveu em um grave caso de corrupção. Após medidas terem sido tomadas e seus demonstrativos contábeis republicados, a empresa apresentou lucro no último exercício social.

Na nota explicativa que versa sobre os riscos nos quais a entidade está submetida, encontra-se transcrito trecho abaixo que versa sobre os riscos operacionais:

\section{Trecho da Nota Explicativa}

"Conforme as boas práticas de governança e gerenciamento de riscos, a Mineradora G possui estrutura para que estes sejam efetivamente identificados, mensurados, avaliados e reportados. Para tanto, existem uma série de órgãos responsáveis..."

Com base na informação acima transcrita, você compraria uma ação dessa empresa?

( ) $\mathrm{Sim}$

( ) Não

\section{Questão 6}

Suponha que ao final do ano passado, você tenha comprado 2 ações da Empresa $H$ ao preço de R \$ 5,00 cada uma. Após a divulgação das Demonstrações Contábeis do último exercício, a empresa apresentou um prejuízo, em virtude majoritariamente da situação econômica ruim em que o país vem passando. Tal fato fez com que o preço da ação caísse para $\mathrm{R} \$ 4,00$. Você ainda compraria outra ação dessa empresa? 
() $\mathrm{Sim}$

( ) Não

\section{Questão 7}

O Banco I constituiu uma estimativa para perdas com Créditos de Liquidação Duvidosa no valor de R\$ 1000 (em milhões de reais). Após análise da nota explicativa que versa sobre o tema, verificou-se que todos esses créditos vão vencer durante o próximo exercício societário e que estes são compostos por 100 clientes independentes entre si com igual probabilidade de cada um entrar em uma situação de inadimplência.

Suponha que você trabalhe na área de crédito do referido banco. Após estudos internos realizados, o Banco I decidiu propor uma renegociação da dívida para os clientes. Estudos anteriores revelaram que $60 \%$ dos clientes aceitam renegociar suas dívidas. Para tanto, o Banco I já ligou para 10 clientes. Destes, somente o segundo cliente não aceitou os novos termos da negociação. Sabe-se que o $11^{\circ}$ cliente é do mesmo setor que o segundo cliente e vem passando por situação financeira análoga. Em sua opinião, este cliente:

( ) Aceitará a nova proposta de renegociação dos termos da dívida

( ) Não aceitará a nova proposta de renegociação dos termos da dívida

\section{Questão 8}

Suponha que você tenha compilado os resultados dos últimos dez exercícios da Empresa J. Não obstante, o preço da ação apresentou uma correlação de 0,96 com o Resultado do Exercício. Abaixo, encontram-se os mesmos discriminados:

\begin{tabular}{|c|c|}
\hline Exercício & $\begin{array}{c}\text { Resultado do Exercício (em milhões de } \\
\text { Reais) }\end{array}$ \\
\hline $01 / 01 / 2015$ a 31/12/2015 & 400 \\
\hline $01 / 01 / 2014$ a 31/12/2014 & 650 \\
\hline $01 / 01 / 2013$ a 31/12/2013 & 700 \\
\hline $01 / 01 / 2012$ a 31/12/2012 & 900 \\
\hline $01 / 01 / 2011$ a 31/12/2011 & 800 \\
\hline $01 / 01 / 2010$ a 31/12/2010 & 680 \\
\hline $01 / 01 / 2009$ a 31/12/2009 & 700 \\
\hline $01 / 01 / 2008$ a 31/12/2008 & 600 \\
\hline $01 / 01 / 2007$ a 31/12/2007 & 500 \\
\hline $01 / 01 / 2006$ a 31/12/2006 & 800 \\
\hline
\end{tabular}

Com base unicamente nas informações acima, você compraria a ação dessa empresa?

( ) $\mathrm{Sim}$

( ) Não

Caso desejar, deixe-me seu e-mail para que eu possa enviar os achados de minha pesquisa quando a mesma estiver finalizada.

E-mail:

Agradeço a atenção. 
Apêndice 3 - Versão 1 do Questionário Submetido aos Analistas de Mercado de uma Grande Instituição Financeira

\section{Questionário}

Prezado colega, meu nome é Roberto Bomgiovani Cazzari e sou discente do programa de doutorado em Controladoria e Contabilidade da FEA/USP. Se possível, gostaria de contar com a sua colaboração respondendo ao questionário abaixo. É importante salientar que a pesquisa versa sobre processo de tomada de decisão com base na divulgação de informações contábeis e financeiras. Agradeço desde já pela colaboração.

\section{$\underline{\text { Parte } 1 \text { - Perfil Acadêmico e Social }}$}

\section{Gênero:}
( ) Masculino

( ) Feminino

\section{Estado Civil:}
( ) Solteiro(a)
( ) Casado(a)/ Em União Estável
( ) Divorciado(a)
( ) Viúvo(a)

Idade:

Quantos Filhos(as) você Possui?
( ) Nenhum
( ) 1
( ) 2
( ) 3
( ) 4
( ) 5 ou Mais

Curso(s) em que se formou:

Já investiu em renda variável? (Ações, Derivativos, etc.)
( ) $\mathrm{Sim}$
( ) Não

Já investiu em renda fixa? (Títulos do Governo, Debêntures, CDB, Letras, etc.)
( ) $\mathrm{Sim}$
( ) Não

Você usa os relatórios financeiros e contábeis divulgados pelas empresas para embasar seu processo de tomada de decisão?
( ) $\mathrm{Sim}$
( ) Não 


\section{Parte 2 - Perfil de Decisão}

Observação: Todos os demonstrativos financeiros ressaltados nesse questionário foram publicados em IFRS.

\section{Questão 1}

Suponha que no papel de um analista de mercado de capitais, você esteja passando por dois problemas concomitantemente. Em ambos, você recomendou a compra de ações para um mesmo cliente. Agora que as demonstrações contábeis foram divulgadas, você se deparou com novos dados.

\section{Decisão 1:}

Em 31 de Dezembro de 2014, seu cliente, sob sua recomendação adquiriu 100 ações ordinárias da Seguradora $\mathrm{B}$ que trabalha com grandes riscos a um preço estipulado em $\mathrm{R} \$$ 35,00 cada uma. Para tanto, você se baseou em análises de mercado que sugeriam que o preço da ação iria crescer. Após a divulgação, em abril de 2015, das demonstrações contábeis referentes ao exercício de 2014, a Seguradora B apresentou um lucro sem precedentes na história da companhia, o que fez com que o preço de sua ação ordinária aumentasse para $\mathrm{R} \$$ 45,00. A seguir, encontra-se a nota explicativa divulgada pela Seguradora B que trata dos passivos contingentes e um trecho de uma reportagem obtida em um jornal econômico de grande circulação.

\section{Nota Explicativa da Seguradora B}

Os Passivos Contingentes da Seguradora $\mathrm{B}$ realçam riscos potencias no tocante às ações cíveis, trabalhistas e fiscais nas quais o grupo econômico está submetido.

Não foram reconhecidos contabilmente os valores envolvidos em uma ação civil movida por um cliente contra a seguradora, devido ao indeferimento do pagamento de sinistro por suposto uso de má-fé do cliente. A avaliação jurídica da empresa estimou que o risco total seja de aproximadamente $40 \%$ do Patrimônio Líquido, porém o mesmo é remoto, sendo que sua probabilidade de não ocorrência é de $90 \%$.

\section{Trecho do Jornal Econômico}

A Seguradora B apresentou ontem o seu maior lucro líquido divulgado em toda a história da companhia. Analistas esperam que o atual exercício seja de grande bonança, o que poderia elevar o preço de sua ação ordinária para $\mathrm{R} \$ 55,00$ até o final de ano. Apesar de tudo, a ação civil movida pelo cliente $X$ pode levar o preço da ação à $\mathrm{R} \$ 30,00$, o que seria um desastre para os atuais possuidores do papel.

Com base nos textos acima retratados, você recomendaria a venda da ação agora ou no final do ano?
( ) Agora
( ) Final do Ano

\section{Decisão 2:}


Para o exercício findo em 31 de Dezembro de 2014, a Empresa C apresentou um prejuízo de $\mathrm{R} \$ 300$ (em milhões de reais), o que trouxe desconfiança a todo o mercado, tendo em vista que foi o primeiro ano em que a empresa apresentou prejuízo. Após análise detalhada das demonstrações contábeis publicadas em IFRS, você notou que isso se devia à desvalorização dos ativos financeiros disponíveis a venda pela entidade.

Não obstante, você percebeu que historicamente, em 10\% dos casos, os ativos financeiros mantidos a valor justo sofriam grandes valorizações. Logo as estimativas apontavam que se isso acontecesse novamente, o lucro líquido do próximo período seria de R $\$ 100$ (em milhões de reais). Caso contrário, o prejuízo poderia ser ainda maior, atingindo os R $\$ 500$ (em milhões de reais).

Como profissional de investimentos de uma grande corretora, você tinha recomendado a compra da ação da empresa dois meses atrás para um grande cliente. Infelizmente, o mesmo acabou por perder dinheiro, dado a subsequente desvalorização dos títulos mobiliários da Empresa C após a divulgação de seus resultados. Na época da compra da ação, seu preço era $\mathrm{R} \$ 20,00$. Após a divulgação dos resultados, o preço da ação foi para $\mathrm{R} \$ 10,00$ e caso as estimativas pessimistas se confirmarem, poderá valer $\mathrm{R} \$ 2,00$. Na visão otimista, a mesma passaria a valer $\mathrm{R} \$ 25,00$.

O que você recomendaria ao cliente?

( ) Que ele as vendesse imediatamente

( ) Que ele mantivesse as ações até o final do ano

\section{Questão 2}

Em 31 de dezembro de 2015, o Patrimônio Líquido da Empresa A (setor de varejo) totalizava $\mathrm{R} \$ 1.000$ (em milhões de reais). Abaixo, encontra-se transcrita a nota explicativa de risco de mercado da Empresa A.

\section{Nota Explicativa - Empresa A}

O risco de mercado é o risco de que o valor justo ou os fluxos de caixa futuros de instrumento financeiro oscilem devido a mudanças nos preços de mercado. $O$ risco de mercado compreende três tipos de risco: o risco da moeda, da taxa de juros e outros riscos de preços.

A gestão de risco do mercado da Empresa A objetiva minimizar a exposição do grupo aos diferentes riscos em que os instrumentos financeiros acabam por gerar, tais como exposição cambial e de taxa de juros.

As análises do risco de mercado são feitas através dos seguintes procedimentos:

- Estimação do Valor em Risco (VaR): considera a perda econômica potencial máxima a que a entidade está submetida, dado um intervalo de tempo e um nível de confiança previamente adotados;

- VaR Estressado: medida obtida do VaR que considera cenários de extrema volatilidade; 
- Teste de Estresse: simulações efetuadas para se verificar como diferentes ativos e passivos reagem às situações em que variáveis de mercado se comportam de modo extremado.

Com base nas estimativas estatísticas realizadas, verificou-se que para o próximo ano, a um nível de confiança de 95\%, pode-se dizer que o VaR de todo a Empresa é de R\$ 100 (em milhões de reais), isto é, somente em 5\% dos casos que ela perderá mais do que R\$ 100 (em milhões de reais).

Com base unicamente nessas informações, você recomendaria a compra da ação dessa empresa?
() $\mathrm{Sim}$
( ) Não

\section{Questão 3}

Abaixo, encontra-se versão resumida do balanço patrimonial divulgado pela Empresa D (setor de varejo) para o último exercício societário:

Empresa D

Balanço Patrimonial Consolidado

(Em milhões de Reais)

\begin{tabular}{|l|c|l|c|}
\hline & $31 / 12 / 2015$ & & $31 / 12 / 2015$ \\
\hline Ativo Circulante & 5.500 & Passivo Circulante & 4.500 \\
\hline & & & \\
\hline $\begin{array}{l}\text { Ativo Realizável a } \\
\text { Longo Prazo }\end{array}$ & 500 & $\begin{array}{l}\text { Passivo Exigível a } \\
\text { Longo Prazo }\end{array}$ & 1.500 \\
\hline & & & \\
\hline & 800 & & \\
\hline Imobilizado & 100 & Patrimônio Líquido & 900 \\
\hline Intangível & & & 6.900 \\
\hline & 6.900 & Total do Passivo & \\
\hline Total do Ativo & & &
\end{tabular}

Recentemente o diretor financeiro da empresa D buscou contato com o Banco no qual você trabalha para discutir sobre a possibilidade de receber um financiamento de $\mathrm{R} \$ 4500$ (em milhões de reais) para ser quitado em 12 parcelas no próximo ano. Supondo que você seja o responsável por tomar essa decisão, você aprovaria o empréstimo?
( ) $\operatorname{Sim}$
( ) Não

\section{Questão 4}

No último exercício societário, o Banco E apresentou um lucro nunca antes visto na história do país. Abaixo, encontra-se discriminada a Demonstração de Resultados do último exercício: 
Banco E

Demonstração dos Resultados

(Em milhões de Reais)

\begin{tabular}{|l|c|}
\hline & De 01/01/2015 a 31/12/2015 \\
\hline Recita de Juros e Rendimentos & 5.000 \\
\hline Despesa de Juros e Rendimentos & $(2.500)$ \\
\hline Receita de Serviços & 3.100 \\
\hline Resultado com Operações de Seguros & 2.400 \\
\hline Despesas Gerais e Administrativas & $(1.000)$ \\
\hline Despesas Tributárias & $(1.500)$ \\
\hline $\begin{array}{l}\text { Resultado de Participação sobre o Lucro } \\
\text { Líquido da Seguradora F }\end{array}$ & 4.000 \\
\hline Imposto de Renda e Contribuição Social & $(3230)$ \\
\hline Lucro Líquido & 6.270 \\
\hline
\end{tabular}

Suponha que você trabalhe em uma grande corretora. Recentemente, um importante cliente no qual você recomendou a compra das ações do Banco E veio te procurar perguntando se você achava interessante que ele comprasse as ações da Seguradora F como forma de garantir um lucro no resultado com ações no próximo período. Você sugeriria essa compra?
( ) $\operatorname{Sim}$
( ) Não

\section{Questão 5}

Suponha que há 2 anos, uma grande empresa mineradora se envolveu em um grave caso de corrupção. Após medidas terem sido tomadas e seus demonstrativos contábeis republicados, a empresa apresentou lucro no último exercício social.

Na nota explicativa que versa sobre os riscos nos quais a entidade está submetida, encontra-se transcrito trecho abaixo que versa sobre os riscos operacionais:

\section{Trecho da Nota Explicativa}

"Conforme as boas práticas de governança e gerenciamento de riscos, a Mineradora G possui estrutura para que estes sejam efetivamente identificados, mensurados, avaliados e reportados. Para tanto, existem uma série de órgãos responsáveis..."

Com base na informação acima transcrita, você compraria uma ação dessa empresa?
( ) $\operatorname{Sim}$
( ) Não

\section{Questão 6}

Suponha que ao final do ano passado, você tenha comprado 2 ações da Empresa $H$ ao preço de $\mathrm{R}$ \$,00 cada uma. Após a divulgação das Demonstrações Contábeis do último exercício, a 
empresa apresentou um lucro um pouco abaixo do esperado pelo mercado, o que fez com que o preço da ação caísse para $\mathrm{R} \$ 4,00$. Você ainda compraria outra ação dessa empresa?

( ) $\mathrm{Sim}$

( ) Não

\section{Questão 7}

O Banco I constituiu uma estimativa para perdas com Créditos de Liquidação Duvidosa no valor de R\$ 1000 (em milhões de reais). Após análise da nota explicativa que versa sobre o tema, verificou-se que todos esses créditos vão vencer durante o próximo exercício societário e que estes são compostos por 100 clientes independentes entre si com igual probabilidade de cada um entrar em uma situação de inadimplência.

Suponha que você trabalhe na área de crédito do referido banco. Após estudos internos realizados, o Banco I decidiu propor uma renegociação da dívida para os clientes. Estudos anteriores revelaram que $60 \%$ dos clientes aceitam renegociar suas dívidas. Para tanto, o Banco I já ligou para 10 clientes. Destes, somente o segundo cliente não aceitou os novos termos da negociação. Sabe-se que o $11^{\circ}$ cliente é do mesmo setor que o segundo cliente e vem passando por situação financeira análoga. Em sua opinião, este cliente:

( ) Aceitará a nova proposta de renegociação dos termos da dívida

( ) Não aceitará a nova proposta de renegociação dos termos da dívida

\section{Questão 8}

Suponha que você tenha compilado os resultados dos últimos dez exercícios da Empresa J. Não obstante, o preço da ação apresentou uma correlação de 0,96 com o Resultado do Exercício. Abaixo, encontram-se os mesmos discriminados:

\begin{tabular}{|c|c|}
\hline Exercício & $\begin{array}{c}\text { Resultado do Exercício (em milhões de } \\
\text { Reais) }\end{array}$ \\
\hline $01 / 01 / 2015$ a 31/12/2015 & 400 \\
\hline $01 / 01 / 2014$ a 31/12/2014 & 650 \\
\hline $01 / 01 / 2013$ a 31/12/2013 & 700 \\
\hline $01 / 01 / 2012$ a 31/12/2012 & 900 \\
\hline $01 / 01 / 2011$ a 31/12/2011 & 800 \\
\hline $01 / 01 / 2010$ a 31/12/2010 & 680 \\
\hline $01 / 01 / 2009$ a 31/12/2009 & 700 \\
\hline $01 / 01 / 2008$ a 31/12/2008 & 600 \\
\hline $01 / 01 / 2007$ a 31/12/2007 & 500 \\
\hline $01 / 01 / 2006$ a 31/12/2006 & 800 \\
\hline
\end{tabular}

Com base unicamente nas informações acima, você compraria a ação dessa empresa?

( ) Sim

( ) Não

Caso desejar, deixe-me seu e-mail para que eu possa enviar os achados de minha pesquisa quando a mesma estiver finalizada.

E-mail:

Agradeço a atenção. 
Apêndice 4 - Versão 2 do Questionário Submetido aos Analistas de Mercado de uma Grande Instituição Financeira

\section{Questionário}

Prezado colega, meu nome é Roberto Bomgiovani Cazzari e sou discente do programa de doutorado em Controladoria e Contabilidade da FEA/USP. Se possível, gostaria de contar com a sua colaboração respondendo ao questionário abaixo. É importante salientar que a pesquisa versa sobre processo de tomada de decisão com base na divulgação de informações contábeis e financeiras. Agradeço desde já pela colaboração.

\section{$\underline{\text { Parte } 1 \text { - Perfil Acadêmico e Social }}$}

\section{Gênero:}
( ) Masculino

( ) Feminino

\section{Estado Civil:}
( ) Solteiro(a)
( ) Casado(a)/ Em União Estável
( ) Divorciado(a)
( ) Viúvo(a)

Idade:

Quantos Filhos(as) você Possui?
( ) Nenhum
( ) 1
( ) 2
( ) 3
( ) 4
( ) 5 ou Mais

Curso(s) em que se formou:

Já investiu em renda variável? (Ações, Derivativos, etc.)
( ) $\mathrm{Sim}$
( ) Não

Já investiu em renda fixa? (Títulos do Governo, Debêntures, CDB, Letras, etc.)
( ) $\mathrm{Sim}$
( ) Não

Você usa os relatórios financeiros e contábeis divulgados pelas empresas para embasar seu processo de tomada de decisão?
( ) $\mathrm{Sim}$
( ) Não 


\section{Parte 2 - Perfil de Decisão}

Observação: Todos os demonstrativos financeiros ressaltados nesse questionário foram publicados em IFRS.

\section{Questão 1}

Suponha que no papel de um analista de mercado de capitais, você esteja passando por dois problemas concomitantemente. Em ambos, você recomendou a compra de ações para um mesmo cliente. Agora que as demonstrações contábeis foram divulgadas, você se deparou com novos dados.

\section{Decisão 1:}

Em 31 de Dezembro de 2014, seu cliente, sob sua recomendação adquiriu 100 ações ordinárias da Seguradora $\mathrm{B}$ que trabalha com grandes riscos a um preço estipulado em $\mathrm{R} \$$ 35,00 cada uma. Para tanto, você se baseou em análises de mercado que sugeriam que o preço da ação iria crescer. Após a divulgação, em abril de 2015, das demonstrações contábeis referentes ao exercício de 2014, a Seguradora B apresentou um lucro sem precedentes na história da companhia, o que fez com que o preço de sua ação ordinária aumentasse para $\mathrm{R} \$$ 45,00. A seguir, encontra-se a nota explicativa divulgada pela Seguradora B que trata dos passivos contingentes e um trecho de uma reportagem obtida em um jornal econômico de grande circulação.

\section{Nota Explicativa da Seguradora B}

Os Passivos Contingentes da Seguradora $\mathrm{B}$ realçam riscos potencias no tocante às ações cíveis, trabalhistas e fiscais nas quais o grupo econômico está submetido.

Não foram reconhecidos contabilmente os valores envolvidos em uma ação civil movida por um cliente contra a seguradora, devido ao indeferimento do pagamento de sinistro por suposto uso de má-fé do cliente. A avaliação jurídica da empresa estimou que o risco total seja de aproximadamente $40 \%$ do Patrimônio Líquido, porém o mesmo é remoto, sendo que sua probabilidade de não ocorrência é de $90 \%$.

\section{Trecho do Jornal Econômico}

A Seguradora B apresentou ontem o seu maior lucro líquido divulgado em toda a história da companhia. Analistas esperam que o atual exercício seja de grande bonança, o que poderia elevar o preço de sua ação ordinária para $\mathrm{R} \$ 55,00$ até o final de ano. Apesar de tudo, a ação civil movida pelo cliente $X$ pode levar o preço da ação à $\mathrm{R} \$ 30,00$, o que seria um desastre para os atuais possuidores do papel.

Com base nos textos acima retratados, você recomendaria a venda da ação agora ou no final do ano?
( ) Agora
( ) Final do Ano

\section{Decisão 2:}


Para o exercício findo em 31 de Dezembro de 2014, a Empresa C apresentou um prejuízo de $\mathrm{R} \$ 300$ (em milhões de reais), o que trouxe desconfiança a todo o mercado, tendo em vista que foi o primeiro ano em que a empresa apresentou prejuízo. Após análise detalhada das demonstrações contábeis publicadas em IFRS, você notou que isso se devia à desvalorização dos ativos financeiros disponíveis a venda pela entidade.

Não obstante, você percebeu que historicamente, em $10 \%$ dos casos, os ativos financeiros mantidos a valor justo sofriam grandes valorizações. Logo as estimativas apontavam que se isso acontecesse novamente, o lucro líquido do próximo período seria de R $\$ 100$ (em milhões de reais). Caso contrário, o prejuízo poderia ser ainda maior, atingindo os $\mathrm{R} \$ 500$ (em milhões de reais).

Como profissional de investimentos de uma grande corretora, você tinha recomendado a compra da ação da empresa dois meses atrás para um grande cliente. Infelizmente, o mesmo acabou por perder dinheiro, dado a subsequente desvalorização dos títulos mobiliários da Empresa $\mathrm{C}$ após a divulgação de seus resultados. Na época da compra da ação, seu preço era $\mathrm{R} \$ 20,00$. Após a divulgação dos resultados, o preço da ação foi para $\mathrm{R} \$ 10,00$ e caso as estimativas pessimistas se confirmarem, poderá valer $\mathrm{R} \$ 2,00$. Na visão otimista, a mesma passaria a valer $\mathrm{R} \$ 25,00$.

O que você recomendaria ao cliente?

( ) Que ele as vendesse imediatamente

( ) Que ele mantivesse as ações até o final do ano

\section{Questão 2}

Em 31 de dezembro de 2015, o Patrimônio Líquido da Empresa A (setor de varejo) totalizava $\mathrm{R} \$ 1.000$ (em milhões de reais). Abaixo, encontra-se transcrita a nota explicativa de risco de mercado da Empresa A.

\section{Nota Explicativa - Empresa A}

O risco de mercado é o risco de que o valor justo ou os fluxos de caixa futuros de instrumento financeiro oscilem devido a mudanças nos preços de mercado. $O$ risco de mercado compreende três tipos de risco: o risco da moeda, da taxa de juros e outros riscos de preços.

A gestão de risco do mercado da Empresa A objetiva minimizar a exposição do grupo aos diferentes riscos em que os instrumentos financeiros acabam por gerar, tais como exposição cambial e de taxa de juros.

As análises do risco de mercado são feitas através dos seguintes procedimentos:

- Estimação do Valor em Risco (VaR): considera a perda econômica potencial máxima a que a entidade está submetida, dado um intervalo de tempo e um nível de confiança previamente adotados;

- VaR Estressado: medida obtida do VaR que considera cenários de extrema volatilidade; 
- Teste de Estresse: simulações efetuadas para se verificar como diferentes ativos e passivos reagem às situações em que variáveis de mercado se comportam de modo extremado.

Com base nas estimativas estatísticas realizadas, verificou-se que para o próximo ano, a um nível de significância de 5\%, pode-se dizer que o VaR de todo a Empresa é de R\$ 100 (em milhões de reais), isto é, em 95\% dos casos, o banco não perderá mais do que R $\$ 100$ (em milhões de reais).

Com base unicamente nessas informações, você recomendaria a compra da ação dessa empresa?
() $\mathrm{Sim}$
( ) Não

\section{Questão 3}

Abaixo, encontra-se versão resumida do balanço patrimonial divulgado pela Empresa D (setor de varejo) para o último exercício societário:

Empresa D

Balanço Patrimonial Consolidado

(Em milhões de Reais)

\begin{tabular}{|l|c|l|c|}
\hline & $31 / 12 / 2015$ & & $31 / 12 / 2015$ \\
\hline Ativo Circulante & 5.500 & Passivo Circulante & 4.500 \\
\hline & & & \\
\hline $\begin{array}{l}\text { Ativo Realizável a } \\
\text { Longo Prazo }\end{array}$ & 500 & $\begin{array}{l}\text { Passivo Exigível a } \\
\text { Longo Prazo }\end{array}$ & 1.500 \\
\hline & & & \\
\hline & 800 & & \\
\hline Imobilizado & 100 & Patrimônio Líquido & 900 \\
\hline Intangível & & & 6.900 \\
\hline & 6.900 & Total do Passivo & \\
\hline Total do Ativo & & &
\end{tabular}

Recentemente o diretor financeiro da empresa D buscou contato com o Banco no qual você trabalha para discutir sobre a possibilidade de receber um financiamento na ordem de 5 vezes o Patrimônio Líquido para ser quitado em 12 parcelas no próximo ano. Supondo que você seja o responsável por tomar essa decisão, você aprovaria o empréstimo?
( ) $\operatorname{Sim}$
( ) Não

\section{Questão 4}

No último exercício societário, o Banco E apresentou um lucro nunca antes visto na história do país. Abaixo, encontra-se discriminada a Demonstração de Resultados do último exercício: 
Demonstração dos Resultados

(Em milhões de Reais)

\begin{tabular}{|l|c|}
\hline & De 01/01/2015 a 31/12/2015 \\
\hline Recita de Juros e Rendimentos & 5.000 \\
\hline Despesa de Juros e Rendimentos & $(2.500)$ \\
\hline Receita de Serviços & 3.100 \\
\hline Resultado com Operações de Seguros & 2.400 \\
\hline Despesas Gerais e Administrativas & $(1.000)$ \\
\hline Despesas Tributárias & $(1.500)$ \\
\hline $\begin{array}{l}\text { Resultado de Participação sobre o Lucro } \\
\text { Líquido da Seguradora F }\end{array}$ & 4.000 \\
\hline Imposto de Renda e Contribuição Social & $(3230)$ \\
\hline Lucro Líquido & 6.270 \\
\hline
\end{tabular}

Suponha que você trabalhe em uma grande corretora. Recentemente, um importante cliente no qual você recomendou a compra das ações do Banco E veio te procurar perguntando se você achava interessante que ele comprasse as ações da Seguradora F como forma de garantir um lucro no resultado com ações no próximo período. Você sugeriria essa compra?

( ) $\operatorname{Sim}$
( ) Não

\section{Questão 5}

Suponha que há 2 anos, uma grande empresa mineradora se envolveu em um grave caso de corrupção. Após medidas terem sido tomadas e seus demonstrativos contábeis republicados, a empresa apresentou lucro no último exercício social.

Na nota explicativa que versa sobre os riscos nos quais a entidade está submetida, encontra-se transcrito trecho abaixo que versa sobre os riscos operacionais:

\section{Trecho da Nota Explicativa}

"Conforme as boas práticas de governança e gerenciamento de riscos, a Mineradora G possui estrutura para que estes sejam efetivamente identificados, mensurados, avaliados e reportados. Para tanto, existem uma série de órgãos responsáveis..."

Com base na informação acima transcrita, você compraria uma ação dessa empresa?
( ) Sim
( ) Não

\section{Questão 6}

Suponha que ao final do ano passado, você tenha comprado 2 ações da Empresa $H$ ao preço de R \$ 5,00 cada uma. Após a divulgação das Demonstrações Contábeis do último exercício, a empresa apresentou um prejuízo, em virtude majoritariamente da situação econômica ruim em que o país vem passando. Tal fato fez com que o preço da ação caísse para $\mathrm{R} \$ 4,00$. Você ainda compraria outra ação dessa empresa?
( ) $\mathrm{Sim}$
( ) Não 


\section{Questão 7}

O Banco I constituiu uma estimativa para perdas com Créditos de Liquidação Duvidosa no valor de R\$ 1000 (em milhões de reais). Após análise da nota explicativa que versa sobre o tema, verificou-se que todos esses créditos vão vencer durante o próximo exercício societário e que estes são compostos por 100 clientes independentes entre si com igual probabilidade de cada um entrar em uma situação de inadimplência.

Suponha que você trabalhe na área de crédito do referido banco. Após estudos internos realizados, o Banco I decidiu propor uma renegociação da dívida para os clientes. Estudos anteriores revelaram que $60 \%$ dos clientes aceitam renegociar suas dívidas. Para tanto, o Banco I já ligou para 10 clientes. Destes, somente o segundo cliente não aceitou os novos termos da negociação. Sabe-se que o $11^{\circ}$ cliente é do mesmo setor que o segundo cliente e vem passando por situação financeira análoga. Em sua opinião, este cliente:

( ) Aceitará a nova proposta de renegociação dos termos da dívida

( ) Não aceitará a nova proposta de renegociação dos termos da dívida

\section{Questão 8}

Suponha que você tenha compilado os resultados dos últimos dez exercícios da Empresa J. Não obstante, o preço da ação apresentou uma correlação de 0,96 com o Resultado do Exercício. Abaixo, encontram-se os mesmos discriminados:

\begin{tabular}{|c|c|}
\hline Exercício & $\begin{array}{c}\text { Resultado do Exercício (em milhões de } \\
\text { Reais) }\end{array}$ \\
\hline $01 / 01 / 2015$ a 31/12/2015 & 400 \\
\hline $01 / 01 / 2014$ a 31/12/2014 & 650 \\
\hline $01 / 01 / 2013$ a 31/12/2013 & 700 \\
\hline $01 / 01 / 2012$ a 31/12/2012 & 900 \\
\hline $01 / 01 / 2011$ a 31/12/2011 & 800 \\
\hline $01 / 01 / 2010$ a 31/12/2010 & 680 \\
\hline $01 / 01 / 2009$ a 31/12/2009 & 700 \\
\hline $01 / 01 / 2008$ a 31/12/2008 & 600 \\
\hline $01 / 01 / 2007$ a 31/12/2007 & 500 \\
\hline $01 / 01 / 2006$ a 31/12/2006 & 800 \\
\hline
\end{tabular}

Com base unicamente nas informações acima, você compraria a ação dessa empresa?

\section{( ) $\mathrm{Sim}$}

( ) Não

Caso desejar, deixe-me seu e-mail para que eu possa enviar os achados de minha pesquisa quando a mesma estiver finalizada.

E-mail:

Agradeço a atenção. 